University of Rhode Island

DigitalCommons@URI

Open Access Master's Theses

1989

\title{
Impact of Four Industrial Developments on a Rural Community: The Case of Lakeville, Massachusetts
}

Christopher Robert Curry

University of Rhode Island

Follow this and additional works at: https://digitalcommons.uri.edu/theses

\section{Recommended Citation}

Curry, Christopher Robert, "Impact of Four Industrial Developments on a Rural Community: The Case of Lakeville, Massachusetts" (1989). Open Access Master's Theses. Paper 663.

https://digitalcommons.uri.edu/theses/663

This Thesis is brought to you for free and open access by DigitalCommons@URI. It has been accepted for inclusion in Open Access Master's Theses by an authorized administrator of DigitalCommons@URI. For more information, please contact digitalcommons-group@uri.edu. 


\author{
IMPACT OF FOUR INDUSTRIAL DEVELOPMENTS \\ ON A RURAL COMMUNITY: THE CASE OF \\ LAKEVILLE, MASSACHUSETTS. \\ BY \\ CHRISTOPHER ROBERT CURRY \\ A RESEARCA PROJECT SUBMITTED IN \\ PARTIAL FULFILLMENT OF THE REQUIREMENTS \\ FOR THE DEGREE OF MASTER OF \\ COMMUNITY PLANNING \\ UNIVERSITY OF RHODE ISLAND \\ 1989
}


MASTER OF COMMONITY PLANNING

RESEARCH PROJECT

OF

CHRISTOPHER ROBERT CURRY

Approved:

Major Professor

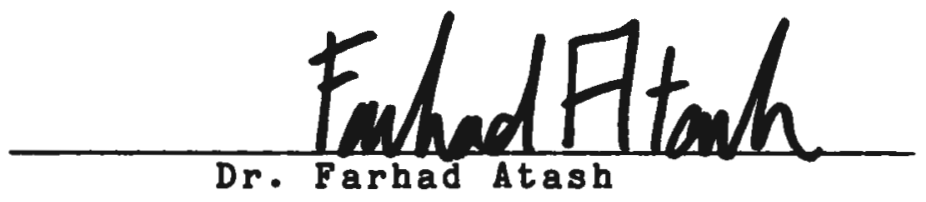

Acknowledged:

Director

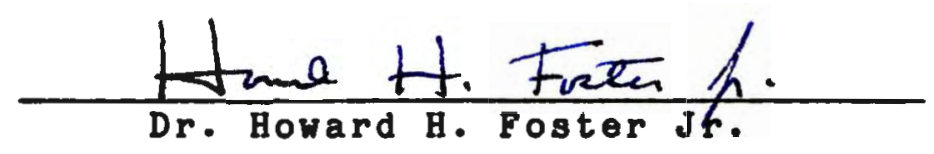




\section{ACKNOWLEDGEMENTS}

The success of this project is directly contributed to the staff of Southern Regional Planning and Economic Development District and I would like to thank them very much. I would particularly like to thank Thomas Pisaturo, Rachel Tedesco and Hillam Napolitano for their contributions and guidance.

Thanks are also extended to my fellow "SRPEDDOn and URI graduate Greg Guimond for giving me the opportunity to work bim on this and other projects, and for volunteering to be my outside reader.

Finally, within the Department of Community Planning and Area Development at the University of Rhode Island, I must thank Farhad Atash for his constant support and words of motivation and Howard Foster for his input and guidance.

Thank you, 
TABLE OF CONTENTS

Page

I. INTRODUCTION

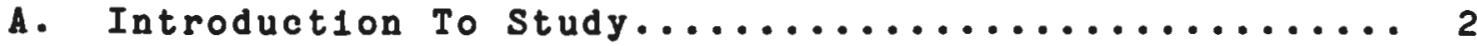

B. Organization of Research......................

II. A PROFILE OF LAREVILLE

A. Lakeville Population

1. Reglonal Sett1ng......................... 6

2. Early Settlement........................ 8

3. Population Characteristics................... 9

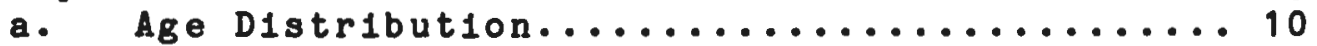

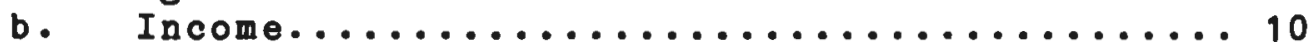

c. Household status....................... 11

d. Housing Characterist1cs................. 11

B. Land Use and Transportation

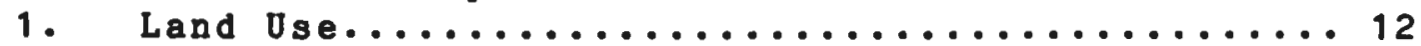

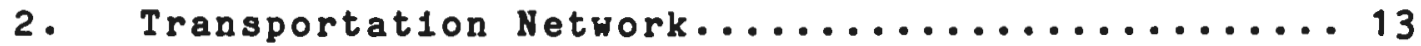

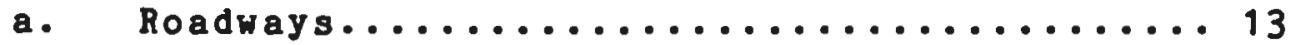

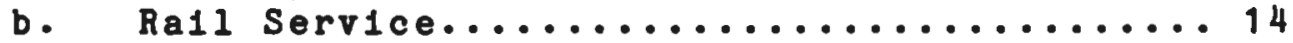

C. Environmental Characteristics

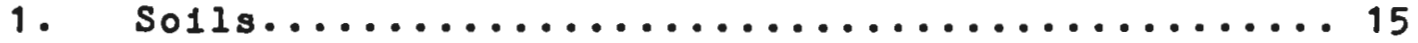

2. Water Resources....................... 16

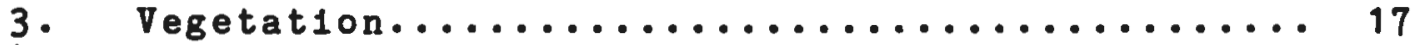

4. vildilfe............................... 17

D. Site Specific Analysis

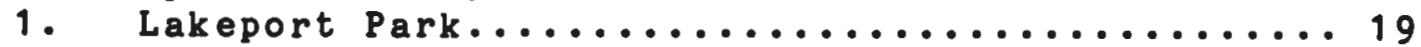

a. Land Dse and Infrastructure............. 19

b. Soll Profile........................ 22

c. Wetlands Profile...................... 24

2. Ocean Spray Corporate Headquarters............ 26

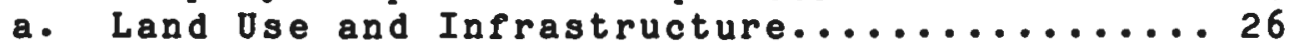

b. So11 Profile......................... 27

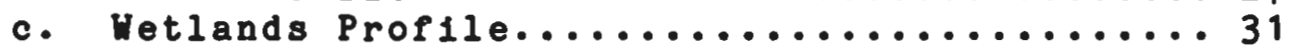

3. Great Ponds Industrial Park................. 32

a. Land Use and Infrastructure............... 32

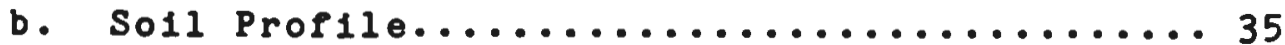

c. Wetlands Profile..................... 37

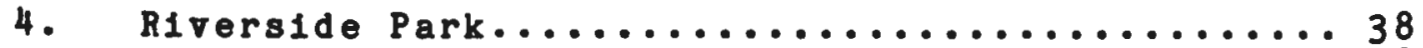

a. Land Use and Infrastructure.............. 38

b. Soll Profile........................ 40

c. Wetlands Profile...................... 42 
page

III. IMPACTS OF DEVELOPMENT

A. Tax Revenue And Primary Employment............. 49

1. Methodolgy........................... 49

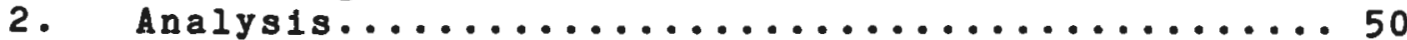

B. Secondary Employment........................ 53

1. Comparative Analysis.................... 59

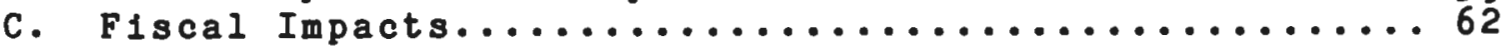

D. Housing and Population Increase............... 65

1. Baseline........................... 65

2. Region of Influence...................... 67

3. Induced Housing Demand \& Population Increase.... 70

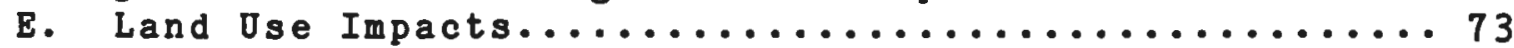

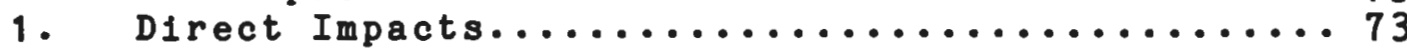

2. Land Consumed Related to Secondary Housing...... 74

3. Secondary Employment Impacts............... 76

F. Housing Affordability...................... 79

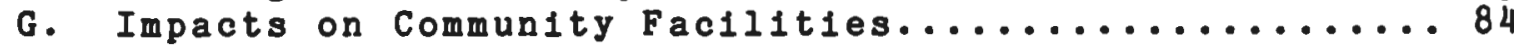

1. Existing Conditions of Lakevilie Facilities..... 84

a. Police Protection................... 84

b. Fire Protection.................... 86

c. Public Water And Sewer ............... 88

2. Projected Direct Impacts................... 89

a. Police Protection..................... 89

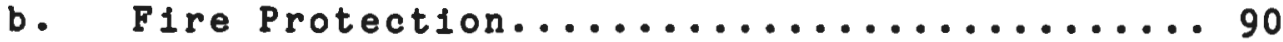

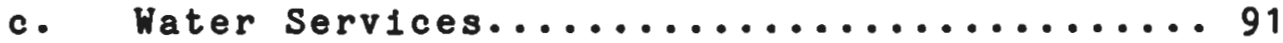

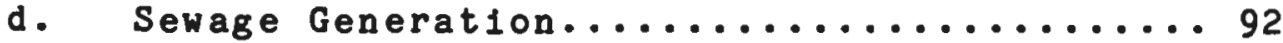

3. Projected Impacts of Induced Population........ 92

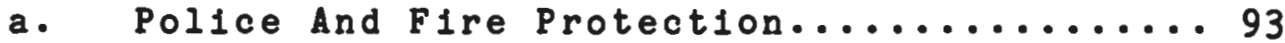

b. Water Use And Sewage Generation.......... 94

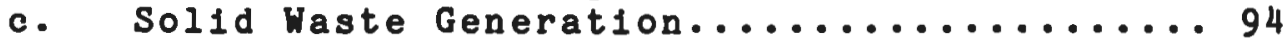

d. Educational Facilities................. 96

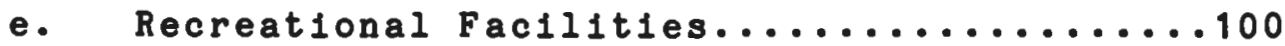

H. Assignment of Transportation Impacts..............102

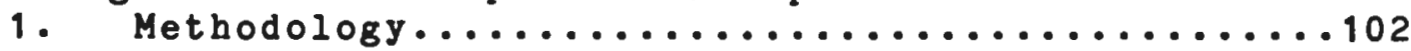

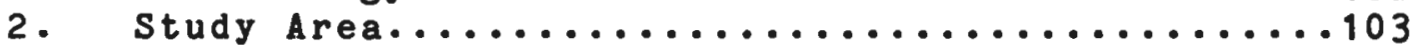

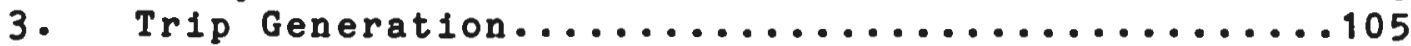

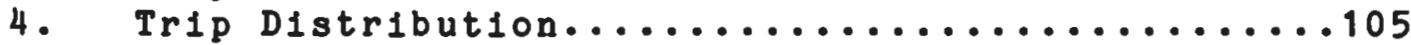

5. Volumne/Capacity Analysis...................115

6. summary.............................119

IV. RECOMMENDATIONS AND ZONING REVISIONS

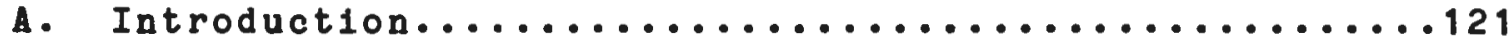

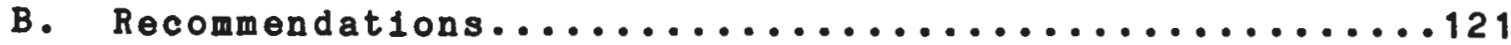

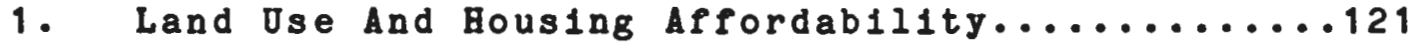

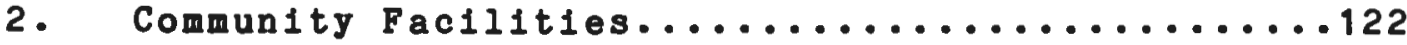

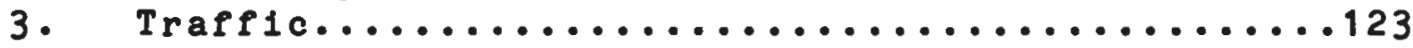

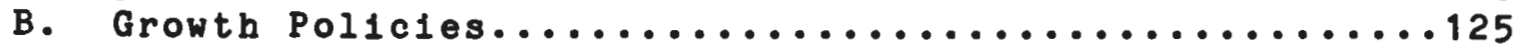

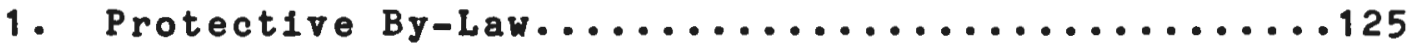

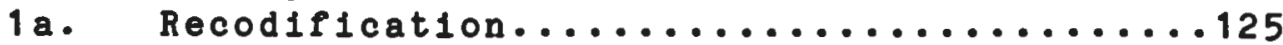

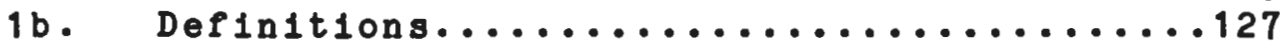

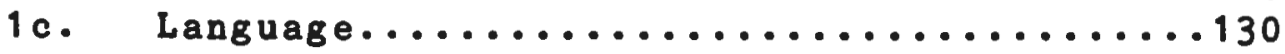




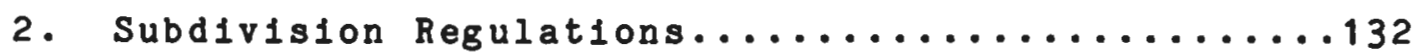

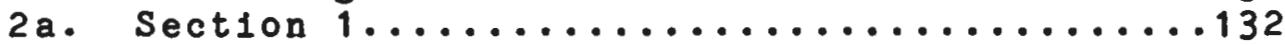

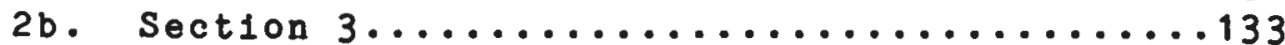

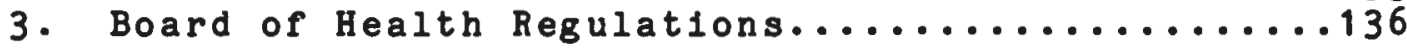

3a. Package Treatment Plant Regulation.......136

3b. Summer Cottage Conversion Regulation.....136

4. Other Appropriate Regulations...............137

4a. Zoning Board of Appeals.............137

\section{V. $\quad$ APPENDICES}

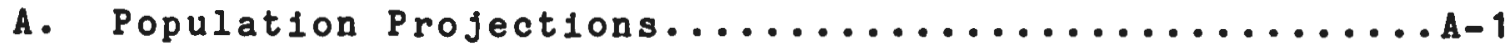

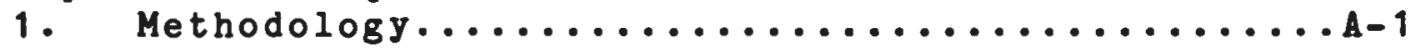

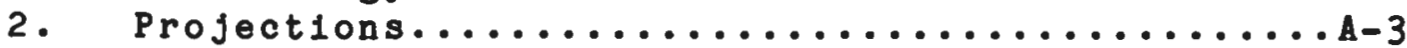

B. Multipliers Osed In Employment Projections..........4

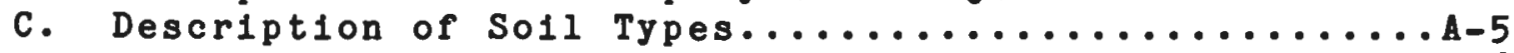

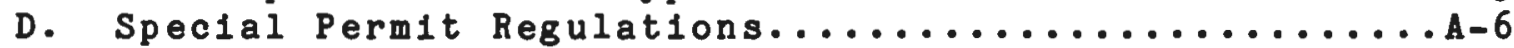

1. Site Plan Review.......................... 6

2. Aquifer Protection By-law...................

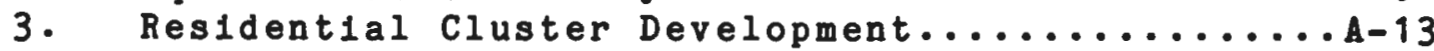

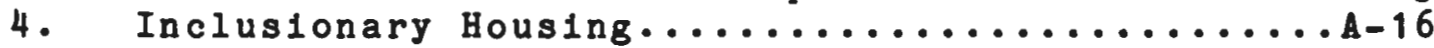

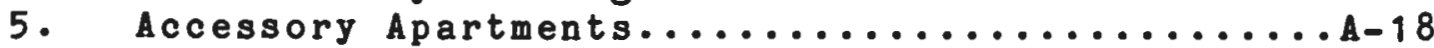

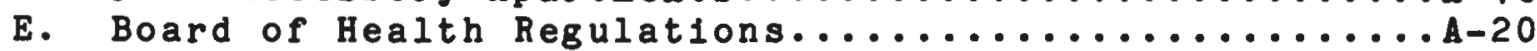

1. Sewage Disposal Regulations Cottage Conversion..A-20

2. Private Waste Water Treatment Facility........A-23 


\section{LIST OF TABLES}

TABLE NUMBER

$\underline{\text { PAGE }}$

1 Lakeville Growth In Population \& Employment..... 8

2 Development Assumptions.................. 51

3 Lakeville Industrial Parks 5 Year Projections... 52

4 Employment Increase 5 Year Summary.......... 55

5 Employment \& Income Projections, Ocean Spray.... 56

6 Employment \& Income Projections, Lakeport Park.. 56

7 Employment \& Income Projections, Great Ponds.... 57

8 Employment \& Income Projections, Riverside Park. 58

9 Comparative Analysis, Socio-Economic..........61

10 Projected Expenditures, Employment Anticipation. 63

11 Estimated Housing Impacts, National Averages... 66

12 Estimated Housing Impacts, Massachusetts...... 72

13 Alternative Zoning Scenarios............. 75

14 Occupations, Plymouth County By Percentages..... 77

15 Projected Secondary Employment By Occupation... 77

16 Cumulative Land Ose Impact of Secondary Emp.... 77

17 Lakeville Housing List Price.............. 80

18 Income From Direct Employment Vs Income Range... 83

19 Existing Facilities.................... 88

20 Projected Police \& Fire Protection Needs....... 93

21 Projected Residential Solid Waste Generation... 95

22 Projected School Age Children............... 98

23 Est1mated Grade Breakdown Of Net Growth....... 99

24 Projected School Expenditures............... 99

25 Vehicle Trips - Peak Hour.................. 100 


\section{LIST OF MAPS}

MAP NUMBER

PAGE

1 Lakeville Regional Setting................... 7

2 Project Locations........................... 20

3 Lakeport Park Site Configuration................ 21

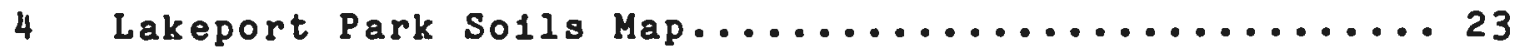

5 Lakeport Park Flood Map..................... 25

6 ocean Spray site Configuration................. 28

7 0cean Spray So1ls Map....................... 29

8 Great Ponds Site Configuration................. 33

9 Great Ponds Soils Map....................... 36

10 Riverside Park Site Configuration............... 39

11 Riverside Park So1ls Map..................... 41

12 Riverside Park Encroachment Into Recharge Area......43

13 Riverside Park Flood Map..................... 45

14 Area Map of 20 Minutes Travel Time To Work........ 68

15 Lakeville Community Facilities................. 85

16 Trip Distribution Raynham Woods.......................

17 Trip Distribution Lakeport Park................109

18 Trip Distribution Ocean Spray Headquarters..........110

19 Trip Distribution Middleborough Development District.111

20 Tr1p Distribution Great Ponds Industrial Park......112

21 Trip Distribution Riverside Business Park.........113

22 Trip Distribution MBTA Train Station..............14 
CHAPTER I

INTRODUCTION 


\section{INTRODUCTION}

The following report is based upon a study produced by the author for the town of Lakeville under the direct supervision of the Southeastern Reglonal Planning and Economic Development District (SRPEDD) in Massachusetts. The project, a growth study as part of a new Master Plan for the Town, was funded by a Massachusetts Strategic Grant Award, made by the Executive Office of Communities and Development.

The significance of this report is the way in which a rural community views industrial development. Lakeville, like a great many other exurban communities, is experiencing pressures of growth resulting from the Boston expansion. And as many other communities have done, Lakeville looked toward industrial development as its tax base savior without consideration of the associated impacts. Thus, for the first time in the Southeastern Regional District a broader view of Industrial growth has been taken, not only that of the Increased tax base but also the resulting negative Impacts.

Therefore, the significance of this study is not so much that of the impacts of the developments in Lakeville, because for the most part it is too late to change these projects, but the way other communities can use the expertise gained by SRPED to analyze future industrial development proposals. 
The objective of this research is to project the type of development which would occur within the four development projects and from those projections, estimate the resulting 1mpacts. Primar1ly, the 1mportant 1mpacts to be analyzed are those directly related to the new Master Plan; they are housing and population increase. The other impacts that are analyzed were spinoffs of the primary 1mpacts.

\section{Organization of Research}

The study is divided into three sections. The first section (Chapter 2) begins with a brief background sketch of Lakev1lie, which discusses the Town in 1ts reglonal setting and early settlement, the population characteristics, the land use and transportation network, and the environmental characteristics. The next level of analysis is that which is site specific to the four developments. This includes the land use and infrastructure of the sites, as well as the soll profile and the wetlands profile.

The second section (Chapter 3) is the analysis of Impacts. It contains direct and secondary employment projections, projections for housing and population increase, general analysis of municipal costs and revenues, land use impacts, housing affordability projections, impacts on community fac1lities, and the transportation 1mpacts generated by the four developments. The methodology employed to develop the 
impact assessments are discussed at the onset of each subsection.

The third and final section (Chapter 4) of the study is the recommendations of the preceding analysis, and the analysis of the existing growth policies. This section delves into the current zoning policies, subdivision regulations, Board of Health regulations, and the requirements of the Zoning Board of Appeal and analyzes them as to their ability to control the projected population increases.

There is also an appendix included at the end of the report which contains the specific multipliers employed in Chapter 3 as well as model by-laws that would help Lakeville maintain an orderly growth pattern. 
CHAPTER II

A PROFILE OF LAREVILLE 


\section{Regional Setting}

Located in the southwestern corner of Plymouth County, Lakeville borders on Berkley, Taunton, Raynham, Middleborough, Rochester, and Freetown. Lakeville lies approximately 40 miles south of Boston, approximately 20 miles northwest of Cape Cod, and 25 miles northeast of Providence, Rhode Island (see Map 1).

As a result of this central location and the completion of Route 495, this region has begun to feel increasing growth pressures. Table 1 displays the growth in population and employment from 1970 to 1980 and from 1980 to 1985 . Though the growth in population has been large, the growth in employment is even greater. This has been a result of the avallability of land and the ample supply of labor and improved access.

The area covered by Southeastern Regional Planning and Economic Development District's (SRPEDD) boundaries registered an unemployment rate of 5.8 percent in 1986 . The increase in the industrial base of Lakeville will help reduce this rate and strengthen the tax base. 


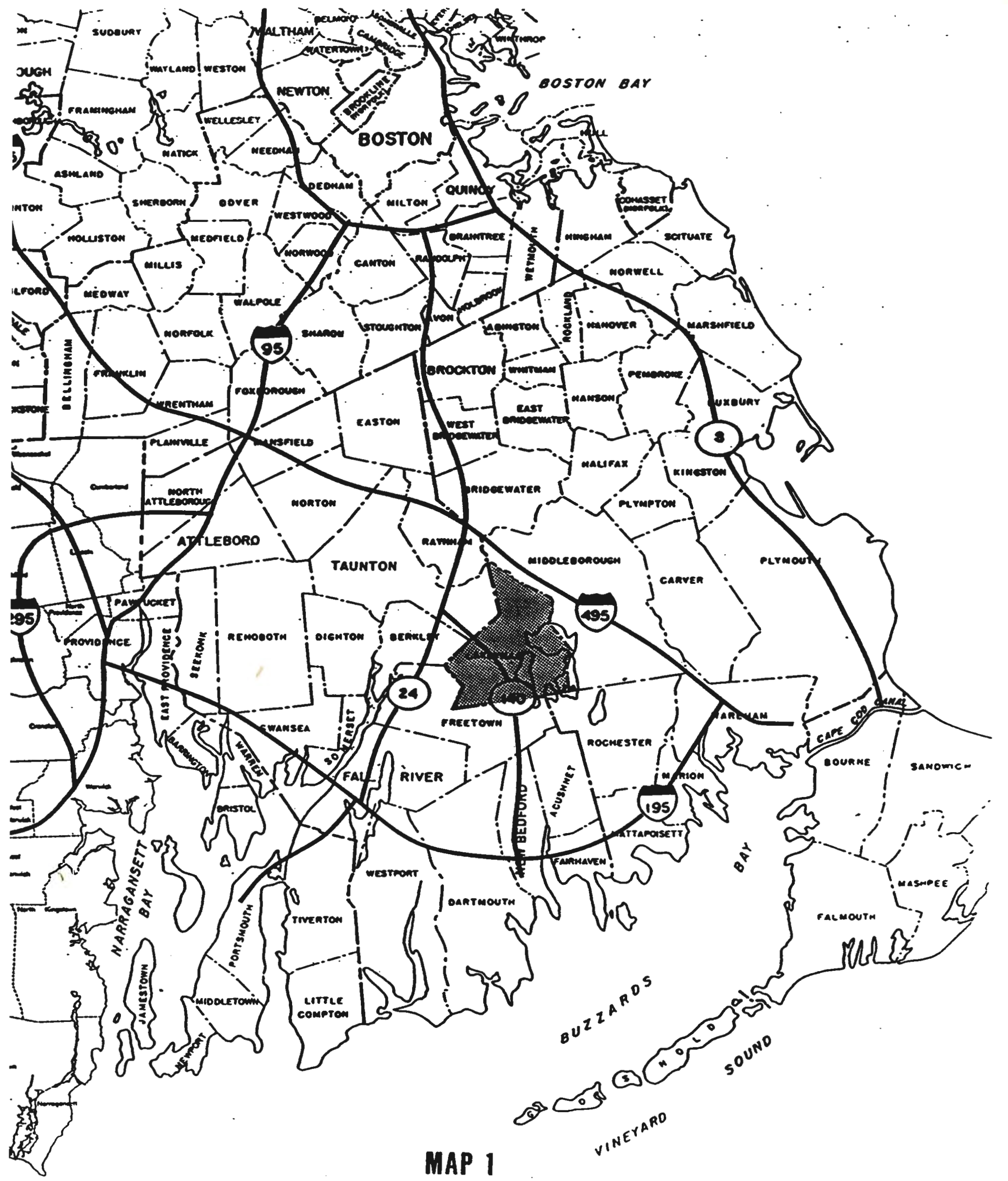


TABLE I

LAKEVILLE GROHTH IN POPULATION AND EMPLOYMENT

1970-1980́ AND 1980-1995

\begin{tabular}{|c|c|c|c|c|}
\hline & $\begin{array}{r}1970-1980 \\
\text { change } \\
\text { Population }\end{array}$ & $\begin{array}{r}1970-1980 \\
x \text { change } \\
\text { Eaployeent }\end{array}$ & $\begin{array}{r}\text { 1980-1985 } \\
\text { x change } \\
\text { Population }\end{array}$ & $\begin{array}{r}\text { 1980-1985 } \\
x \text { change } \\
\text { Enplayoent }\end{array}$ \\
\hline Lakeville & $35.5 \%$ & $31.2 \%$ & $14.4 x$ & $193.9 \%$ \\
\hline Berkley & $34.7 x$ & $53.9 x$ & $15.9 x$ & $278.3 \%$ \\
\hline Freetown & $65.3 \%$ & $86.6 \%$ & $9.8 \%$ & $65.2 \%$ \\
\hline Hiddleborough & $20.6 x$ & $50.2 \%$ & $2.5 \%$ & $39.8 x$ \\
\hline Raynha & $35.5 \%$ & $58.0 \%$ & $-3.2 \%$ & $99.7 \%$ \\
\hline Rochester & $81.1 \mathrm{x}$ & $19.0 \%$ & $7.2 \%$ & $279.0 \%$ \\
\hline Taunton & $2.9 \%$ & 30.94 & $-6.3 x$ & $32.8 \%$ \\
\hline
\end{tabular}

\section{Early Settlenent of Lakerille}

It was believed settlers of European descent came to the Beechwood portion of what was then Middleborough, in about 1709. Unt1l the year 1853, Lakeville comprised about $1 / 3$ of the western portion of Middleborough. In 1717 the first white man settled in Assawompett Neck.

Like many rural communities, Lakeville was home of many diverse industries including tack-making factories, blacksmith shops, shoe manufacturers, soap makers, sawills, tanneries, and shepherding . 
Over the years, Lakeville has seen little change and today the Town 1 s still primarily a residential town with many of the services and features associated with a rural community.

\section{Population Characteristics}

As displayed in Table 1, over the per1od from 1970 to 1980 , the population of Lakeville grow by 35.53 percent raising the total population to 5,931 in 1980 . It 1 s estimated that from 1980 to 1985 , the population grew by 14.4 percent to 6,785. Although the percentage growth has been h1gh, the town still maintains the lmage of an open, rural community. The density of population for Lakevilie is the fifth lowest In the SRPEDD district at 165.82 persons per square mile. The four towns with fewer persons per square mile are Rochester, Plympton, Berkley, and Carver, respectively.

According to the 1980 U.S. Census, the population of Lakeville was predominantly white. Of the 5,931 people in 1980 , there was only 42 non-whites $(0.8 \%)$ and 30 persons of Spanish origin $(0.5 \%)$. Although there was a slight increase In the minority population from 1970 to 1980 , their percentage of the whole population decreased over the same per1od. 
Lakev1lle's median-school-years completed rates in the middle of SRPEDD's communities with 12.5. Marion has the highest with 13 years of school and Fall River the lowest with 9.3 school years completed.

\section{a. Age Distribution}

Lakeville's population is relatively young with 39 percent of the population aged 24 or younger and only 11 percent aged 65 or older. As with most New England communities, the population of Lakevilie has aged since 1970 when 448 of the population was 24 or younger. Thirty percent of the population was between the ages of 25 and 44 in 1980 as compared to 24 percent in 1970 . However, the percent of population for the town has remained the same for 65 and older from 1970 through 1980.

\section{b. Income}

The per capita income for Lakeville was $\$ 6,603$ in 1979. This was above the per capita income for Bristol County $(\$ 6,252)$ but below the per capita income for Plymouth County $(\$ 6,978)$ and the per capita Income for Massachusetts as a whole at $\$ 7,458$. 
According to the 1986 data, Lakeville's estimated per capita income was $\$ 11,205$. This was again in between the figures for Bristol County at $\$ 9,961$ and Plymouth County at $\$ 11,817$.

\section{c. Household Status}

of the 1,901 households in Lakeville in $1980,1,570$ were family households. Seven percent or 107 of the family households were headed by a single parent of which 19 were male-headed and 88 were female-headed.

\section{d. Housing Characteristics}

In 1980 there were a total of 2,426 housing units in Lakeville. 1,980 housing units were designated year round with 1,891 of these units occupied, 89 units vacant and the remaining 446 units occupied on a seasonal basis. Of the 1,891 year round occupled units, 1,707 or about 90.278 were owner occupied and 184 or $9.73 \%$ were renter occupied units. Ninety-six percent of the 1,891 housing units were singlefamily detached structures. By 1980, $26 \%$ of all housing units had been built prior to 1930 . While housing conditions in Lakeville are generally good, there are some substandard units in the town. These are concentrated in the Buena vista Shores area. Buena Vista Shores is an area where seasonal homes located on small lots with poor soll conditions have been converted to year-round use. 
LAND USE AND TRANSPORTATION

\section{Land Use}

The most recent comprehensive land use survey of Lakeville was undertaken in 1971 by Professor William MacConnell of the University of Massachusetts at Amberst. The results of the MacConnell Survey were as follows: Urban land 1,650 acres, 7 percent of the total land area, Mining 216 acres, 1 percent of the land, Recreation 307 acres, 1 percent of the land, Agriculture 3,164 acres, 13 percent of the total land, Wetlands 4,513 acres, 18 percent of the land, and Forest Land at 14,096 acres, or 60 percent of the total land.

The Urban land use category includes industrial, commercial, residential, transportation and open/public. In 1971 there were 0 acres of the land in industrial use, 112 acres in commercial use, 1,229 acres in residential use, 158 acres in transportation use and 151 acres of land classified as urban open/public. The agriculture land use includes farmlands, and cranberry bogs.

A great deal of change has taken place since 1971. Although a comprehensive land survey is well beyond the scope of this study, an easy method for comparison would be the growth in new residential and industrial development. As stated earlier, in 1970 there were 1,318 housing units in Lakeville, 
compared with units in 1985 , an increase of 86 percent.

Furthermore, according to the MacConnell land use survey, there was no land in industrial use in 1971, and today this report is studying four industrial sites totaling 585 acres.

\section{Transportation Network}

\section{a. Roadways}

The Town of Lakeville is served by a number of state highways and major collector roads. Route 140 provides north-south access to Taunton and Fall River via a limited access highway connecting to Routes 24 and 195 . Route 18 provides northsouth access to Middleborough and Freetown. Route 44, though only crossing a short section of north Lakeville, offers east-west access to Plymouth and Providence, Rhode Island.

Other significant traffic routes are the secondary, arterials and collector roadways throughout the town. These include Route 79 , a northeast-southwest access to Fall River and Middleborough, which is presently undergoing upgrading. Route 105 is another north-south route which links Marion to Halifax. Other collector roads include, County Road, Taunton Street, Southworth-Leonard Streets, Clear Pond Road, Vaughan Street, Bridge Street, Precinct Street, Pickens Street, Plerce Avenue, Howland Road, Freetown Street, and Long Point Road. 
An important aspect of the road network of Lakevilie which has not been mentioned is Route I-495. Although this route does not pass through Lakeville, its close proximity to the north-east portion of the town is the driving factor in the Industrial growth which the town is facing. With Interchanges at Routes 44,18 and 105, Lakeville is a perfect location for distribution facilities servicing the Greater Boston as well as northeast regional centers.

\section{b. Ra11 Service}

Lakeville is presently being considered for a rail station by the MBTA for its restored commuter service to the Middleborough line. The site under consideration for the terminal is that of Riverside Park. The Riverside Park site would be the final terminus for the commuter trains and would be served by approximately 25 train trips per day. Although several sites in Middleborough are being investigated by the MBTA for the terminal, they are leaning toward the Riverside Park site for a possible opening date in the next five years. Presently, the rail serves Conrall freight traffic as well as two passenger services, a summer line service from Braintree to Hyannis (the Cape Cod Hyanis line) and an Amtrak service from New York to Cape Cod. 
ENVIRONMENTAL CHARACTERISTICS

1. $\underline{\text { So11s }}$

The general solls profile of the Town of Lakevilie consists of four predominant so1l associations: Essex-GloucesterSc1tuate; H1nckley-WIndsor-Merrimac; Peat-Muck-Norwellfreshwater marsh, and; Charlton complex. These solls vary considerably. They are level to steep, excessively drained and well-drained and very poorly drained. They were formed In sand and gravel, silt materials, glacial till and outwash, and organic materials.

Solls within a general soil group may possess some similarities or differ greatiy in their properties. The deciding factors in their association is that they have generally formed in similar materials, and the dominant soils within the general solis area are the largest in extent in that area.

Sultability of a general soll area for a particular use $1 \mathrm{~s}$ determined by the characteristics of the dominant soil therein. This type of information is contained within the scope of a so11 surveg. 1 soll survey can be used to point out various soll ilmitations for agriculture, septlc system, residential, industrial, or other land uses. Limiting factors considered in such a survey includes: soll behavior 
for selected uses, wetness, composition of soll, stability, slope and friability.

\section{Hater Resources and Hetlands}

Lakeville has an abundance of water resources, including eleven ponds classified as Great Ponds by the Commonwealth of Massachusetts (this pond classification applies to ponds which in their natural state constitute more than ten acres). Th1s pond system provides water resources for Taunton, New Bedford, and under Massachusetts State law, Fall River (although Fall River does not presently utilize its water option in Lakevilie). The estimated safe yield of the Lakeville ponds is approximately 27.5 million gallons per day.

The surrounding wetlands help to malntaln the overall water quality through the removal of silt, water-born nutriments, and pollutants. Another important function of a wetland is to serve as a groundwater recharge area and in surface water flow malntenance. All of these functions are now, more than ever, belng predominantly recognized In Massachusetts wetland regulations. New provisions in the Wetlands Protection Act (MGL Ch. 131 Sec. 40) recognize wetlands and stream banks for thelr Importance as rare and endangered wildife species habitat. 


\section{Vegetat1on}

The plant species occurring in Lakeville are quite like those occurring through the majority of the southeastern portion of Massachusetts. The vast forested areas of Lakeville consist primarily of oak (a high percentage of which is scrub oak), black oak, red oak, pine, pitch pine, maple and red maple. The forests are primarily a mix of hardwoods and soft woods with lesser areas of mostly hardwoods and areas of mostly conifers.

Mosses, grasses and herbaceous plant life common to regional wetlands and forests are scattered throughout Lakeville. Dense scrub and bushy under-growth including blueberries, blackberries, cartbrier and sumac, cranberries and laurel thickets also are found in scrub shrub swamp and bog areas.

\section{H1ldl1fe}

The abundance of woodland, dense scrub growth and a vast supply of freshwater are all factors in the diversity of indigenous species of mammalian, amphibian, and reptilian Iffe in the Lakerilie area. Some of the more commonly observed species are: cottontall rabbit, various hares, chlpmunk, grey squirrel, opossum, deer mouse, raccoon, woodchuck, deer, muskrat, otter, salamanders, mink, various toads, varlous frogs, varlous turtles, garter snake, and 
black racer.

In addition to 1 ts woods and uplands, Lakeville's wetlands, cranberry bogs, streams, and ponds provide an 1deal habitat for such indigenous and migratory wild fowl as: pheasant, blue jay, robln, black duck, wood duck, black-capped chickadee, quall, ruffed grouse, golden eyes, cardinal, crow, swallow, red-talled hawk, osprey, blue bill, blue heron, sparrow, and wren. 


\section{Lakeport Park}

\section{a. Land Use and Infrastructure}

Located on Route 44 at the Taunton line, Lakeport Park is a 65 acre site served by a 12 inch water main from Taunton public water supply. The area surrounding the site is primarily commercial with a small shopping plaza and a self storage facility directly to the west and a retail outlet directly to the east. Across Route 44 is a small section of retall and considerable amount of open space (see Map 2).

The section of Route 44 along which the site lies is fairly wide and straight. There is ample sight visibility from the access point. Furthermore, the Route 44 location is in close proximity to both the Route 24 and Route 495 interchanges.

To date, Lakeport Park contains three bulldings which lie along the front of the site, with a realistic potential for anotber 17 or so buildings. Because of the preliminary character of negotiations regarding this project, and the unrealistic site plan provided by the developer, little can be said about the final development scenario (see Map 3 ). However, all future projections as to levels of employment and tax benefits are based on twenty 25,000 square foot 


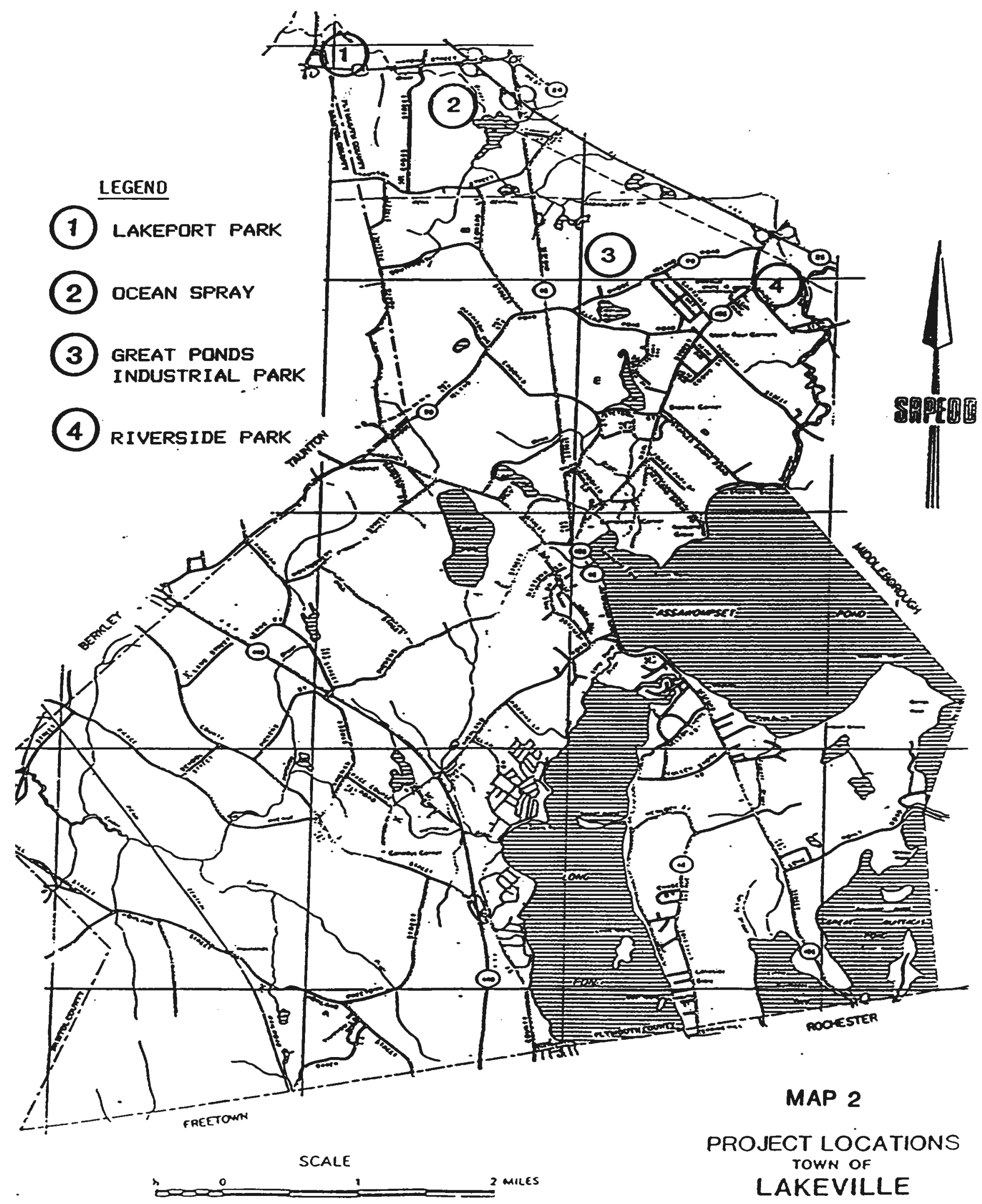




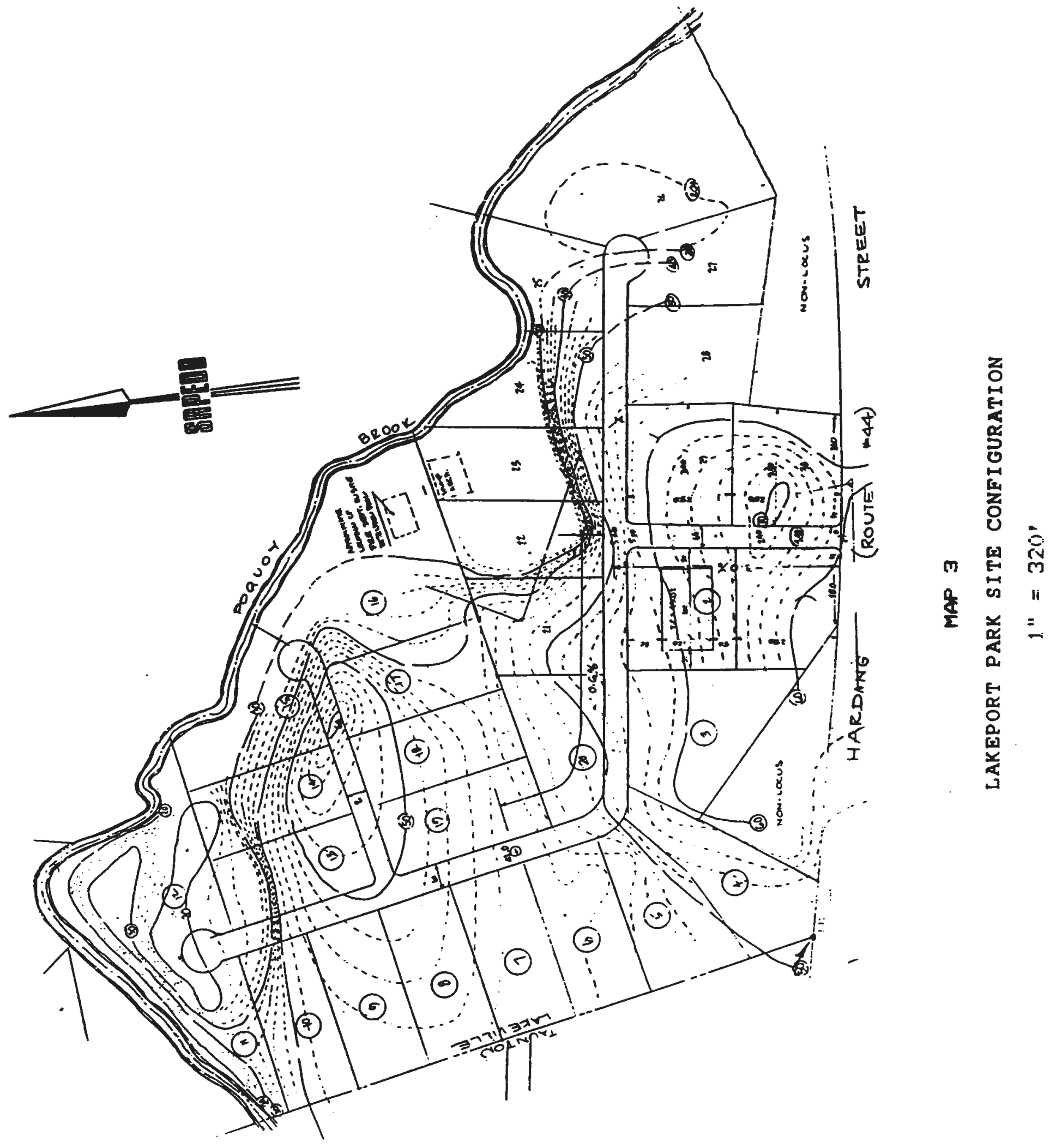


building s.

\section{b. So11s Profile}

This site is comprised primarily of Agwam and Merrimac soils with lesser areas of Hinckley, Raynham and shallow muck (see Map 4). The Agwam, Windsor, Merrimac and Hinckley soils are formed in thick deposits of sand and gravel and are excessively permeable in the upper part of the soil and rapidly to very rapidly permeable in the lower part. Water tables in these solls are generally deep (greater than 6 feet). These soils pose only slight limitations for development.

Raynham solls are poorly drained solls formed in silt and clay. The permeability of these solls is moderately slow or moderate in the upper part and slow in the lower part. The water table is at or near the surface during wet periods of the year. This severely limits the suitability of these solls for building or development.

Mucks are very poorly drained solls developed in well decomposed organic deposits. These solls either have ponded water at the surface or a water table at or near the surface most of the year. These factors, in conjunction with this soil units proximity to Poquoy Brook, severely limits the development potential of this portion of the site. 


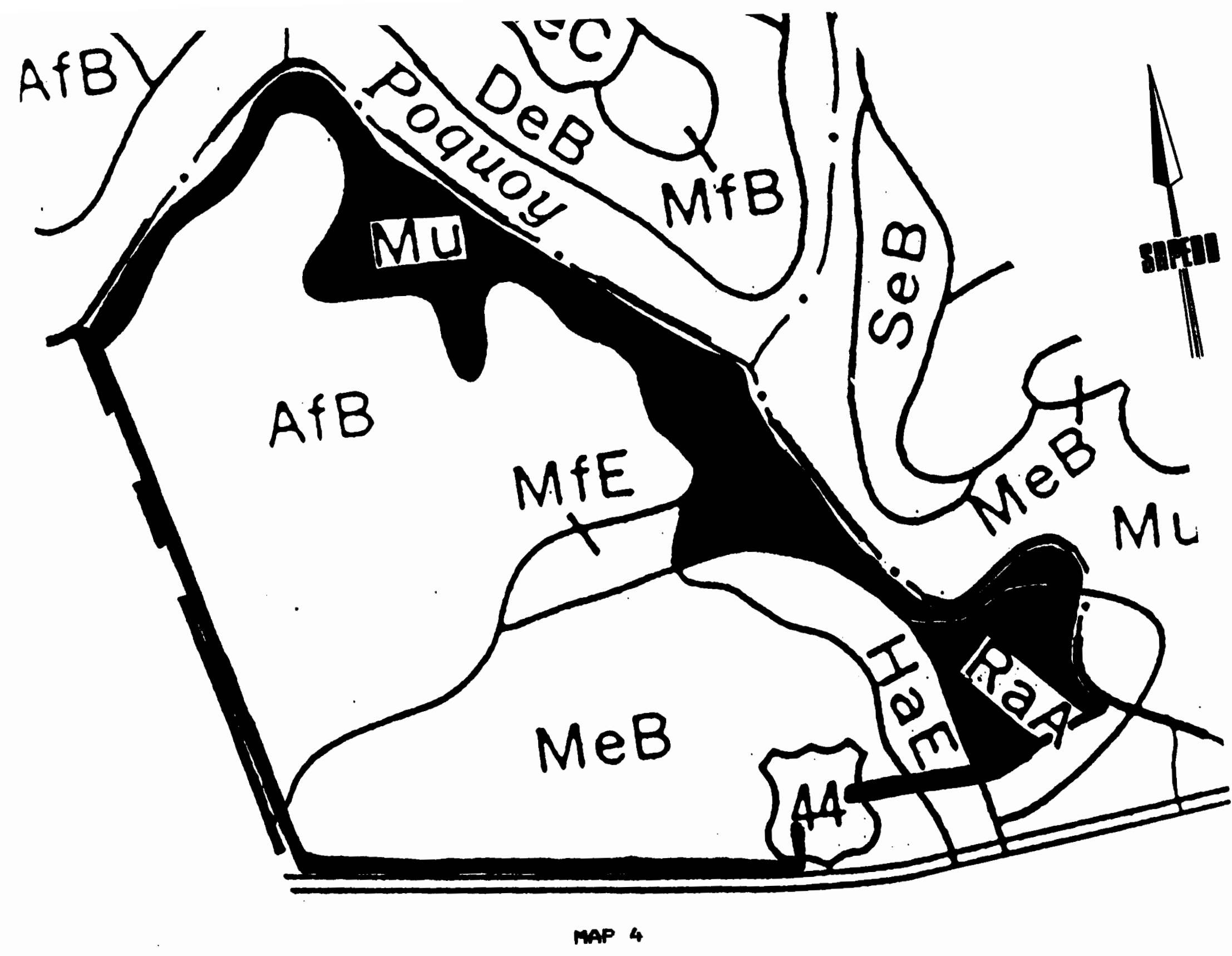

LAKEPORT PARK SOILS MAP

SOILS WITH SEVERE LIMITATIONB 
On this Map, as well as on all of the solls maps, the solls that are not suitable for development are colored in black.

\section{c. Netlands Profile}

Lakeport Park is bordered to north and running along the east by the Poquoy Brook and its freshwater wetland environs. The wetlands, surrounding the immediate path of the brook, are mixed freshwater areas. Building plans should attempt to avoid any intrusion into these wetlands which fall within the approximate 100 year flood boundary as delineated on the 1980 National Flood Insurance Program Floodway Map for the Town of Lakeville (see Map 5). 


\section{Ocean Spray Corporate Headquarters}

\section{a. Landuse and Infrastructure}

The Ocean Spray site $1 \mathrm{~s} 310$ acres of which 60 acres are located in Middleborough and 250 acres are located in Lakeville. It contains a 36 acre pond and a 16 acre cranberry bog. The site is served by an 8 inch sewer main along Route 18 and is hooked into the Middleborough sewer system. Also, there is a 12 inch water main extended from Lakeport Park along Route 44 to the site.

A mixture of land uses surround the site. Along Route 44 there are primarily strip commercial structures, including an auto dealership. Along Route 18 there is a coffee shop and the rest is open space. To the west and south of the site, along cross street and Taunton street, there are primarily residential structures and a public golf course.

Located at the merge of Routes 44,18 and 495 , the Ocean Spray site has great accessibility. The access points on Route 44 and Route 18 have good sight visibility and the internal through street will allow entering and exiting traffic to access the Route 495 interchanges without traveling through the Middleborough rotary. 
Map 6 displays the Ocean Spray project layout, with the headquarters and research and development building at the northern section of the site facing Route 495, and the Cranberry World museum at the southeastern corner of the site. Phase I, to be completed this year, consists of 125,000 square feet of office space and 25,000 square feet of research and development space. There will also be parking facilities for 600 automobiles. Phase II of the project, scheduled for completion in 1995, w1ll consist of another 150,000 square feet of office space and a 10,000 square foot bullding to be used as a museum. The second phase will have additional parking including ten spaces for bus parking.

\section{b. So11s Profile}

This site is composed of large map units of Essex, Agwam, and Sc1tuate soils with lesser areas of Merrimac, Deerfield, Hindsor, Norwell, Au Gres and deep, shallow and sanded muck (see Map 7). The Agwam, Windsor and Merrimac solls are formed in thick deposits of sand and gravel and are excessively well drained. These solls are moderately to rapidly permeable in the upper part of the soll and rapidly to very rapldy permeable in the lower part. Water tables in these so1ls are generally deep (greater than 6 feet). These solls pose only slight limitations for development. 


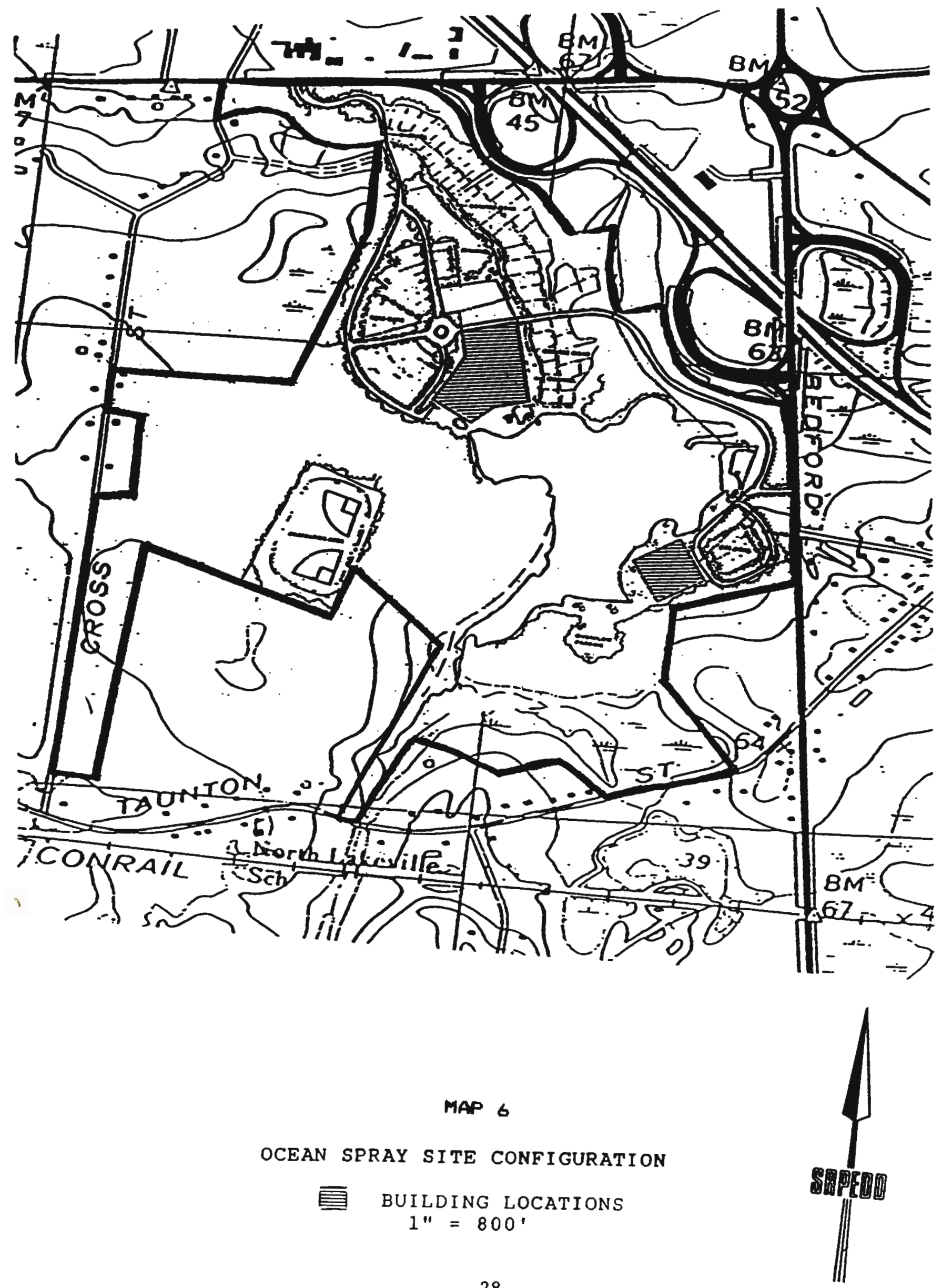




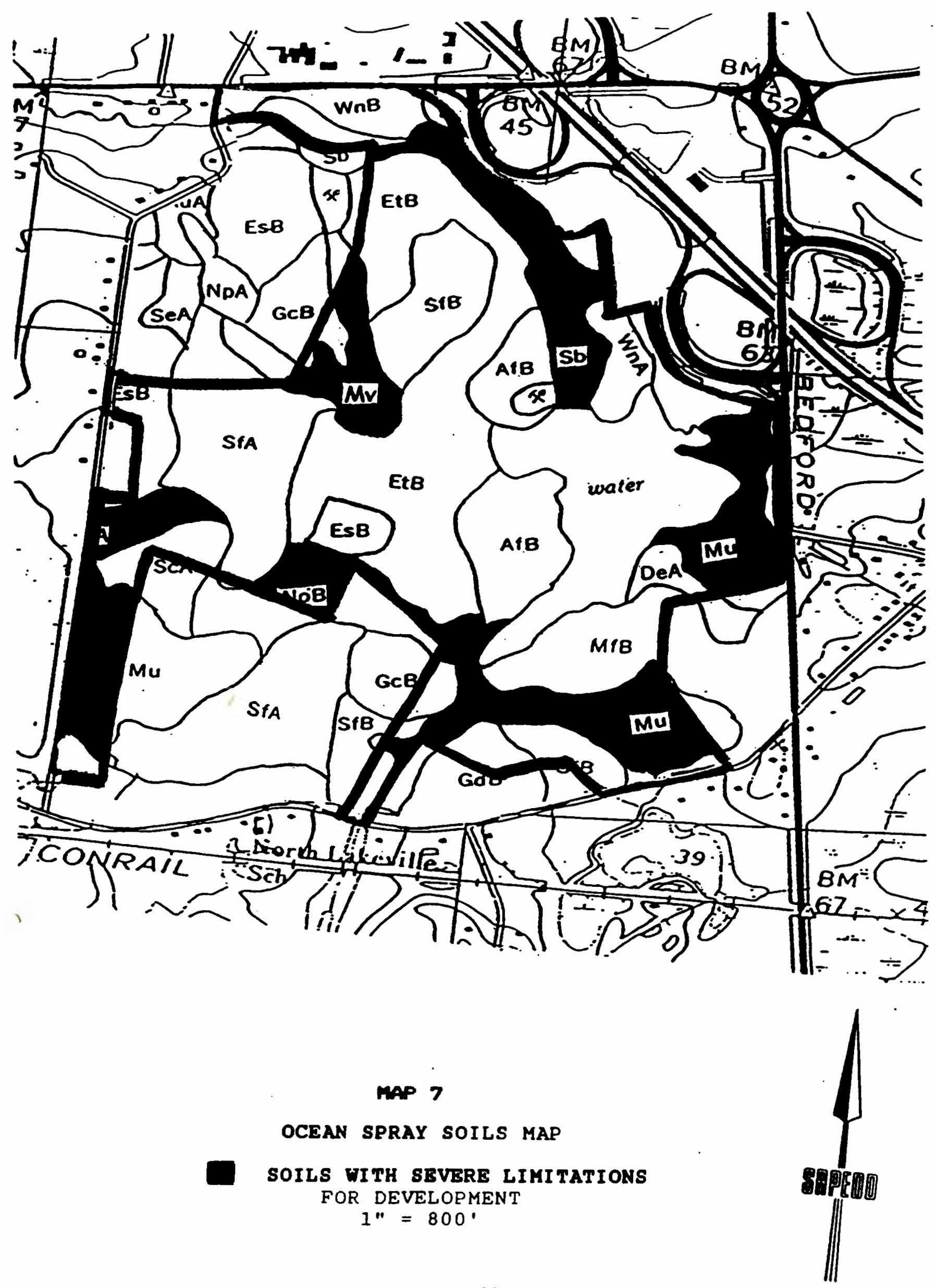


The Essex so1ls are well drained solls that are formed in stony, loose material that is underlain at a shallow depth ( 2 $1 / 2$ to 3 feet) by $11 \mathrm{rm}$, compact materlal referred to locally as hardpan. The permeability of these solls is moderate to moderately rapid in the upper part and slow to very slow in the lower part. Hater tables are generally deep in these solls (greater than 6 feet).

The Sc1tuate so1ls are moderately well drained, formed in stony, loose material that is underlain at a shallow depth ( 2 to 3 feet) by hardpan. Permeability is moderate in the upper part and slow to very slow in the lower part. Hater tables In areas of these so1ls are at a shallow depth ( 1.5 to 4 feet) during wet periods of the year.

Deerfield so1ls are moderately well drained so1ls that have formed deposits of sand and gravel. They are moderately to rapidy permeable in the upper part and rapidly to very rapidly permeable in the lower part of these so1ls. Hater tables are at a shallow depth, ( 1.5 to 4 feet) during wet periods of the year.

The Essex, Scituate and Deerfield solls pose moderate limitations due to seasonal wetness. However, these so1ls can be engineered to accommodate the purpose of this site.

The Norwell and Au Gres solls are poorly and very poorly 
drained mineral solls that have formed in material ranging from sand and gravel to silt and clay. Permeability of these solls varies greatly, depending upon the materials in which they are formed. These solls are wet and have a water table at or near the surface during wet periods of the year, making them largely unsuitable for building.

Mucks are very poorly drained solls developed in well decomposed organic deposits. These solls either have ponded water at the surface or a water table at or near the surface most of the year, making these solls unsultable for development.

\section{c. Hetlands Profile}

Surrounding the buildable portion of the site, from the northeastern corner extending to and along the southern boundary, are mixed freshwater forested scrub shrub swamp areas. These areas are dominated by broad leafed deciduous vegetations. Along the western portion of the site and into the southwestern corner, there exists an area of cranberry bogs and freshwater swamp.

Other than the construction of the primary acoess road, little wetlands intrusion occurs on this site. Rather, much of the natural character of this site is being preserved in the overall construction plan. 


\section{Great Ponds Industrial Park}

\section{a. Landuse and Infrastructure}

The Great Ponds Industrial site is approximately 200 acres and is being developed by the Lakeville Development Corporation (LDC). While the site is served by a 16 inch water main from the City of Taunton, it will not have any public sewer. The site abuts the Lakeville Landfill to the south. The site surrounds the Carrage House Drive and Surrey Drive subdivision to the west. However, there is a 100 foot buffer area that separates the site from the adjacent properties (see Map 8 ).

Great Ponds Park is situated at the junction of Routes 79 and 18. Route 79 is presently a narrow winding road. However, 1t is in the process of being upgraded. Furthermore, upon completion of the Kenneth Welch Drive access to Route 18 traffic problems along Route 79 caused by large trucks will be eased.

The site plan of Great Ponds Industrial Park indicates the location of the Talbot's warehouse and the proposed RixDunnington warehouse. There is also an 80,000 square foot warehouse being built by Thompson Box Compang on the Woodview Corporation property. Dundas Machine Company has recently purchased six acres to build a manufacturing plant. The 


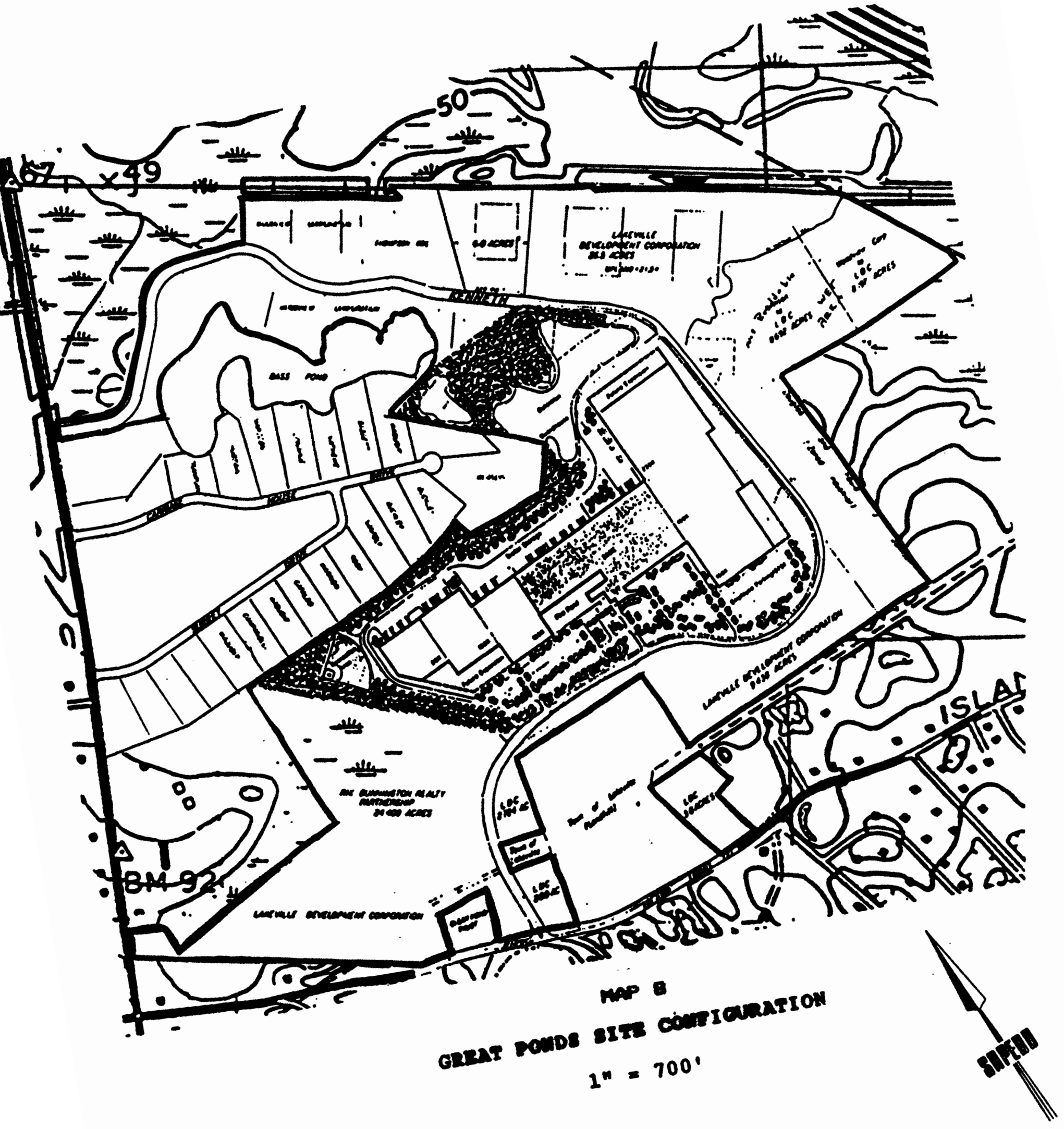


buildout date for the entire complex is best examined by the separate companies involved.

First, Talbot's has completed the first of its projected four phase project on the 82.657 acres which they purchased from the LDC. Phase I is the existing 360,000 square foot distribution center. Phase II will be the expansion of the facility to 627,000 square feet by the year 1993. Phase III and IV are presently targeted for around the year 2000 and will be the expansion of the facility to 1,300,000 square feet.

The Rix-Dunnington warehouse is to be a 100,000 square foot facility to be in operation by 1990. It will be situated on the 24.409 acres at the southwesterly corner of the industrial park. No expansion of this facility is planned at the present time.

The Thompson Box Company should have completed its facility by 1989. The Dundas Machine Company should have its first phase completed by 1989, and its second phase by 1995. The remaining 36 acres of the industrial park should be sold off and built by 2000 . 


\section{b. Solls Profile}

This site is composed primarily of Hinckley soils with lesser areas of Merrimac, Gloucester, sanded muck, shallow muck, deep muck and peat (see Map 9). The Hinckley and Merrimac soils are formed in thick deposits of sand and gravel and are excessively well drained. They are moderately to rapidly permeable in the upper part and rapidly to very rapidly permeable in the lower part. Water tables in these soils are generally deep (greater than 6 feet).

Gloucester soils are well drained soils that have formed in stony,loose soll material. They are rapidly permeable throughout. Water tables are generally greater than 6 feet. The Gloucester, Hinckley and Merrimac solls pose only slight limitations for the planned development purpose.

Peats are very poorly drained solls developed in well decomposed organic deposits. These solls either have ponded water at the surface or a water table at or near the surface most of the year, making them unsultable for building or development. 


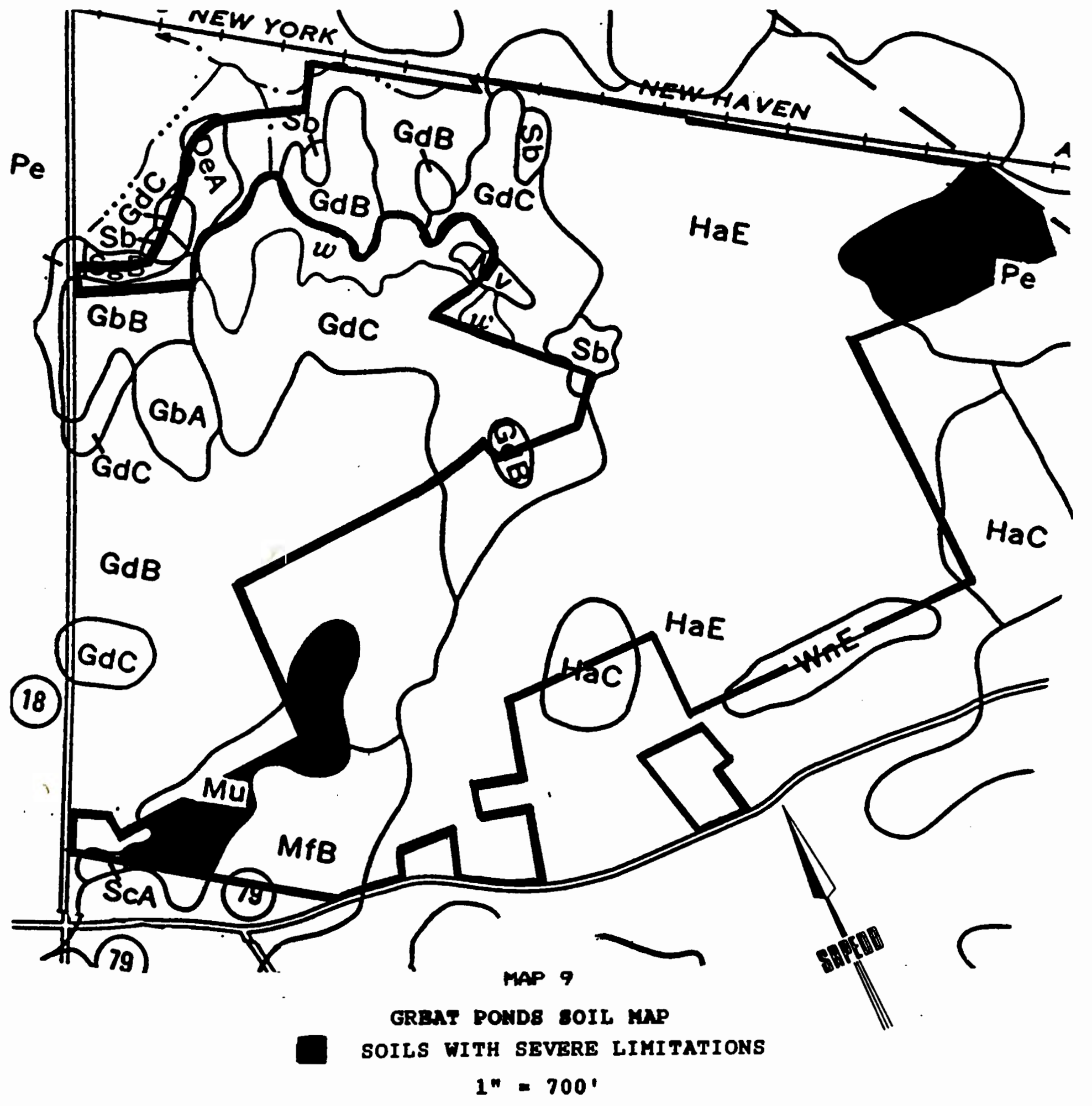


c. Wetlands Profile

The perimeter of this site is surrounded by a variety of wetlands, including mixed freshwater forested scrub shrub swamp, areas of broad leafed deciduous wetland vegetation, freshwater marsh and bogs. There is a minimal amount of wetlands intrusion onto the site in the northwestern corner. There is also an area of hydric soil and wetlands vegetation in the northeastern corner of the site, within the site boundaries. This area, abutting a proposed lot, is undevelopable.

37 
4. R1verside Park

a. Landuse and Infrastructure

Riverside Park is located at the intersection of Route 105 and Route 495. It is a 70 acre site consisting of 22 approved bullding lots. The site will be served by public water from either Middleborough or Taunton, and is the proposed site for the MBTA Middleborough Rall train station (see Map 10).

The site is surrounded by a mixture of commercial (Coldwell Banker, GHR analytical services,and RHS heating sales) and Industrial (Country Press Printing in Lakevilie and the Ocean Spray processing plant in Middleborough) uses and many residential properties. The site's two access points on Route 105, are expected to draw most of traffic directly off of Route 495 and Route 105 and limit interference with Bridge Street.

The plans for the exact development of the Riverside Park are still preliminary. However, according to the owner (First Middleborough Corp.), the site will most likely contain about 750,000 square feet of buildings, of which approximately 65 percent will be warehouse and distribution, 25 percent will be light industrial, and 10 percent will be office and service. The plan also calls for the MBTA acquiring the 


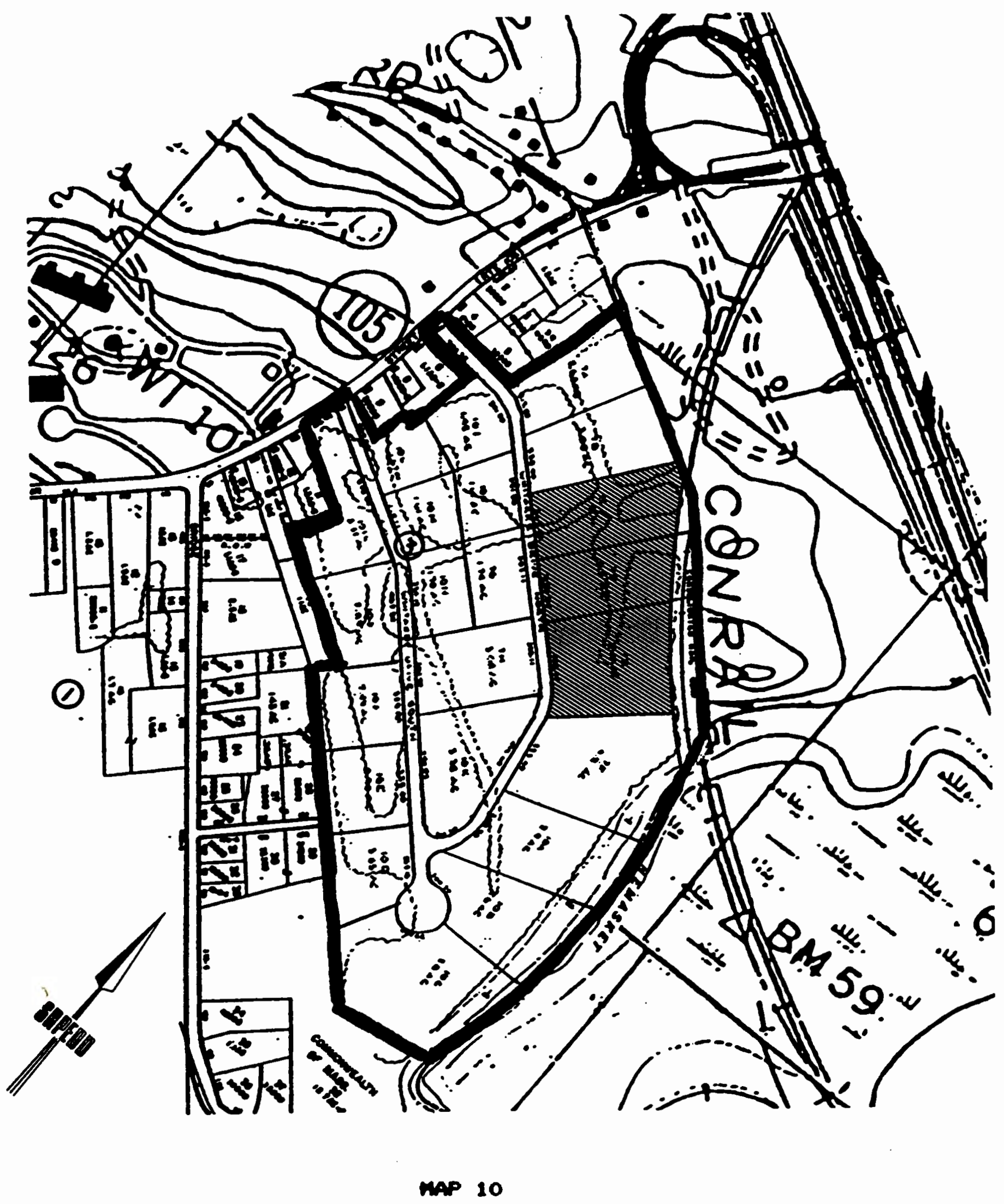

RIVERSIDE PARK SITE CONFIGURATION

MBTA RAIL TERMINAL

$1^{\prime \prime}=500^{\circ}$ 
three lots closest to the rall, as well as the construction of a station on another 8 acre parcel.

The projected completion date for both the rail terminal and the industrial park is 1995. Initially, the rail terminal is expected to be constructed with a 500 car parking lot with a possible expansion of 500 more parking spaces at some future date.

\section{b. So1ls Profile}

This site is composed of large map units of Windsor soils with lesser areas of Au Gres, Scio and Deerfield soils (see Map 11). The Windsor solls are formed in thick deposits of sand and gravel and are excessively well drained. These solls are moderately to rapidly permeable in the upper part and rapidy to very rapidly permeable in the lower part. Hater tables in these solls are generally deep (greater than 6 feet). These soils pose only slight limitations to commercial development.

Deerfield soils are moderately well drained soils that have formed in deposits of sand and gravel. They are moderately to rapidiy permeable in the upper part and rapidy to very rapidy permeable in the lower part of these soils. Water tables are at a sallow depth ( 1.5 to 4 feet) during the wet periods of the year. Halle Deerfield solls pose moderate 


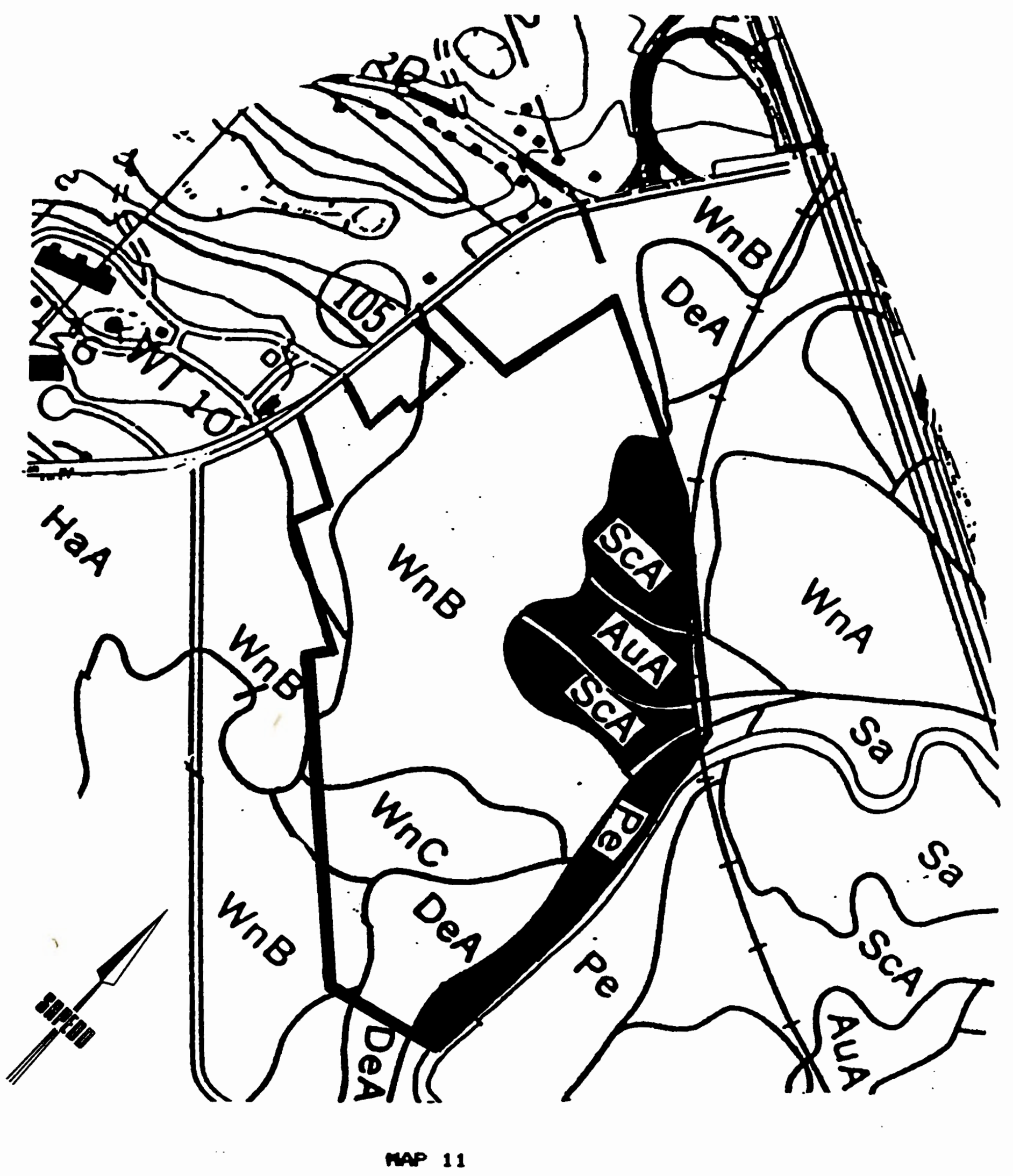

RIVERSIDE PARK SOILS MAP

DOILS WITH SEVERE LIMITATIONS

FOR DEVELOPMENT

$1^{\prime \prime}=500^{\circ}$ 
limitations to development due to their seasonal wetness, they can be engineered to accommodate commercial buildings.

The Au Gres soils are poorly and very poorly drained mineral solls that have formed in material ranging from sand and gravel to silt and clay. Permeability varies greatly, depending upon the materials in which they are formed. These solls are wet and have a water table at or near the surface during wet perlods of the year, making them largely unsuitable for building.

Sc10 so1ls are moderately well drained soils formed in silt material. Permeability of these soils vary greatly depending upon the materials in which they are formed. These solls are wet and have a water table at or near the surface during wet periods of the year. Due to their nature, the development limitations should be addressed on an individual case basis.

\section{c. Hetlands Profile}

This site lies within the furthest western boundary of the East Grove Street Well portion of the Hemasket River Recharge area in the Town of Middleborough (as indicated on the Map 12). Areas of freshwater forested scrub shrub swamp, dominated by broad leafed deciduous vegetation, are found just outside of the northwestern and eastern boundaries of the site and in the proximity of and along the banks of the 


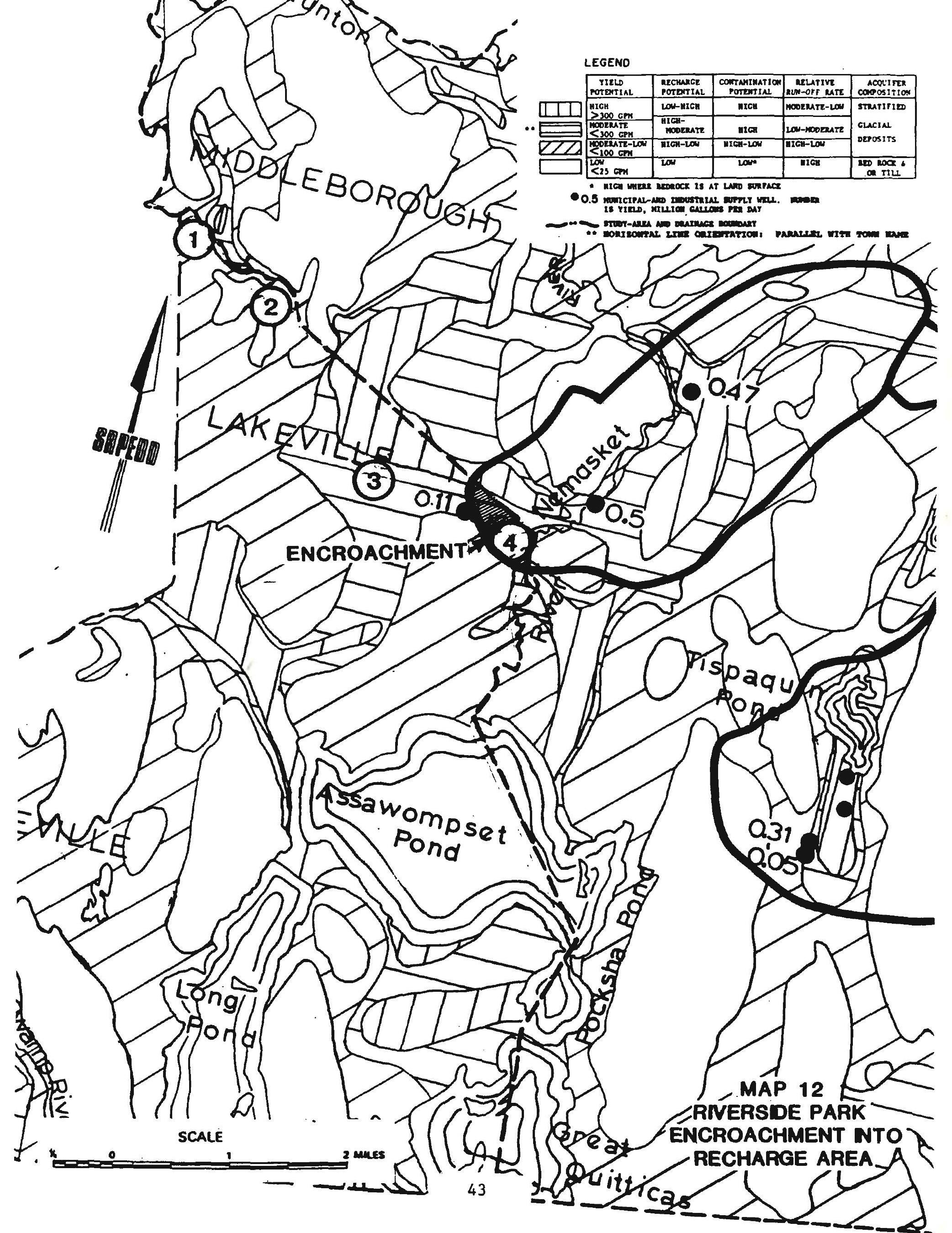


Nemasket River.

The portion of this site that lies within the Nemasket River recharge area is also located within the approximate 100 year flood boundary as delineated on the 1980 National Flood Insurance Program Floodway Map for the Town of Lakeville (Map 13)

The above facts concerning Riverside Park should be taken into consideration regarding proposed development plans. This is particularly important in terms of structural considerations and suitable use. 


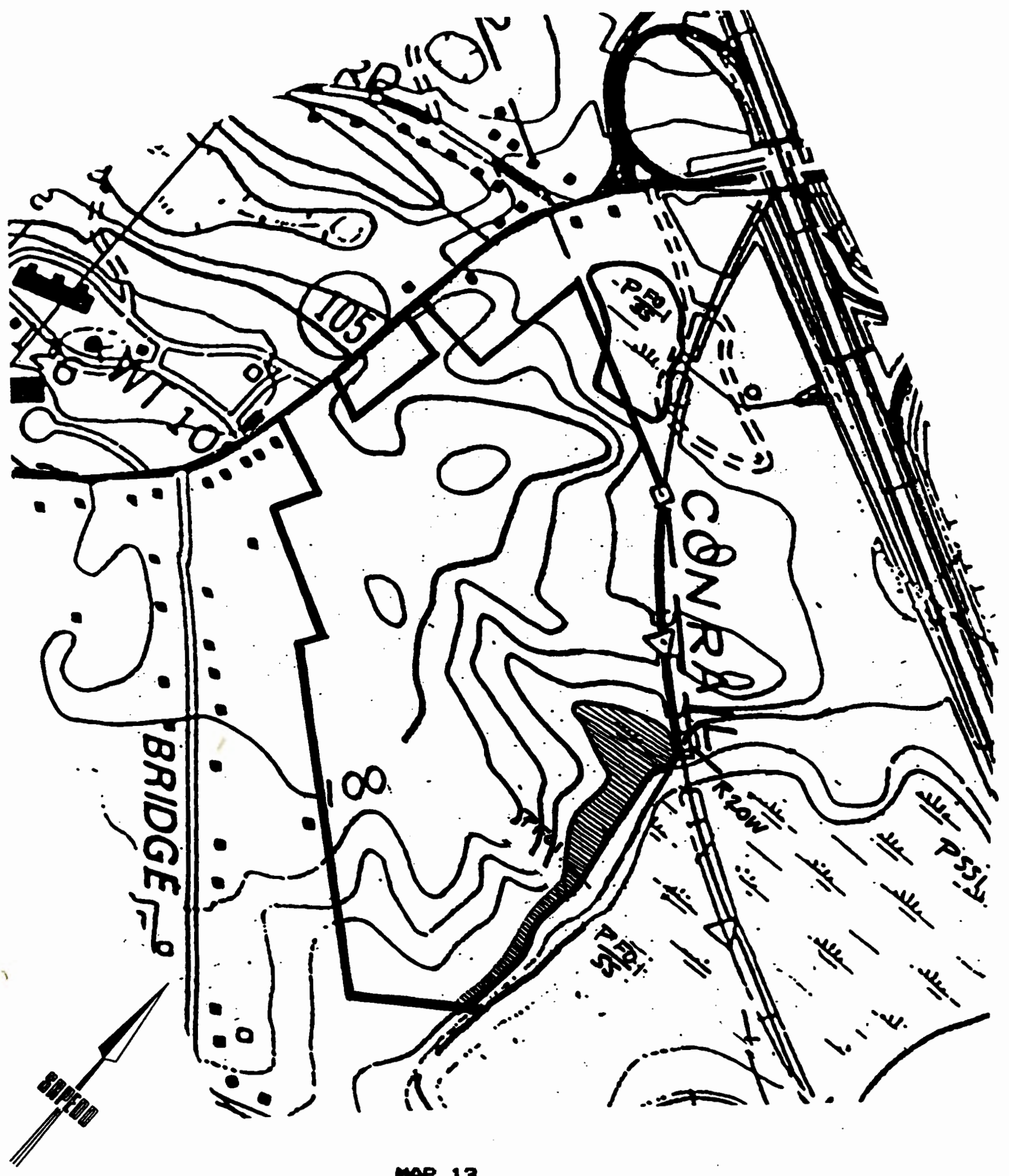

$\operatorname{MAP} 13$

RIVERSIDE PARK FLOOD MAP

FLOOD PLAIN ENCROACHMENT

FOR DEVELOPMENT

$1^{\prime \prime}=500^{\circ}$ 


\section{CHAPTER III}

IMPACTS OF DEVELOPMENT 
INTRODUCTION

The preceding chapter presented a brief overview of the population and land use characteristics of the town of Lakeville, as well as a profile of the four development proposals. This Chapter will present the resulting impacts of the developments upon the town. The impacts that are addressed are listed below.

A. Projections of the primary employment for each of the four developments and the tax benepits to Lakeville.

B. Projections of the secondary employment impacts of the four developments based on national standards and a comparison to several towns in eastern Massachusetts with similar development projects.

C. An estimate of the direct impacts of the four developments on the cost of town services (general government, public safety, public works, health and welfare, recreation, statutory) using an employment anticipation model.

D. In estimate of the percentage of employees in the four developments who will live in Lakeville, the reaulting demand for housing, and the aggregate population increase. 
E. An estimate of land use 1mpacts based on the direct Impacts of the four developments, land consumed by secondary employers, and land used for residential development associated with the four developments.

F. An estimate of the impacts on housing affordability based on the expected increase in population, the Income characteristics of new employees, and the avallability of housing in varlous price ranges as Identified by the Multiple Listing Service.

G. An estimate of the impacts on community facilities based on the direct impacts of the four developments, plus estimates of the need for services related to the Increase in secondary employment and population.

H. An assignment of transportation impacts based on projections of vehicle trips from the four developments and their assignment to the existing circulation system.

The impacts discussed in this section were limited to only those that were quantiflable. 4180 , the impacts are addressed on a five gear basis from 1990 through 2005, throughout this report. 
TAX REVENUE AND PRIMARY EMPLOYMENT

The most fundamental portion of this impact analysis is the estimates of the future municipal revenues, total direct (or primary) employment and total direct wages for each of the four developments. These estimates are based upon assumptions for each development as to the floor area, the type and average cost of construction, industry type and average number of employees per square foot in that given Industry, and the annual wage by industry in the New Bedford SMSA. The estimates are made for five year intervals beginning in 1990 and projected through the year 2005 .

\section{METHODOLOGY}

The methodology employed to estimate the revenues, employment and wages was the simple use of multipliers in association with the projections of the future site plans for each of the four developments.

(a) The estimate of tax revenues were generated by applying the estimates of building value for each given land use obtained from the Mean's Building Cost Manual plus the assessed value of the land, to the Town's tax rate of $\$ 9.70$ per thousand. (b) Primary employment was estimated by use of the Institute of Traffic Engineers multipliers, which represent a national average of employee per square foot of 
building space by the land use.

(c) The wages of the primary employment were estimated by use of the average wage rates in the New Bedford SMSA for the different industrial types. These wage estimates, obtained from the Massachusetts Division of Employment Securities for 1986, were then multiplied by the number of employees in each employment type for three of the four developments. For the Ocean Spray development, more accurate wage data was avallable from their 1985 environmental report (EIR) and thus substituted for the New Bedford SMSA estimates.

\section{ANALYSIS}

Due to the repetition of the information for each of the four developments, the assumptions are shown in Table 2. The actual projections are displayed in Table 3 .

As observed in Table 3 , in 1990 the total real estate taxes generated by the four developments w111 be $\$ 353,186.00$, the direct (or primary) employment will be 1,442 persons, and their wages will be slightly above 28.75 million per year. By the year 2005 , it is projected that the real estate taxes will total approximately 1.2 million dollars, the direct employment w11l reach 5,579 persons, and their wages w11l be around 113.25 m11110n. 
TABLE 2

DEVELOPMENT ASSUMPTIONS

\begin{tabular}{|c|c|c|c|c|c|}
\hline $\begin{array}{l}\text { PROJECT } \\
\text { NAME }\end{array}$ & $\begin{array}{l}\text { DEVELOPENHT } \\
\text { CHARACTERISTICS }\end{array}$ & $\begin{array}{l}\text { BUILDINS } \\
\text { VALUE }\end{array}$ & $\begin{array}{l}\text { TAX RATE } \\
\text { APPLIED TO LAND } \\
\text { PLUS BUILDING }\end{array}$ & $\begin{array}{l}\text { EMPLOYMENT PER } \\
\text { SQUARE FOOT }\end{array}$ & $\begin{array}{l}\text { EMPLOYEE } \\
\text { WAGE RATE }\end{array}$ \\
\hline LAKEFORT PARK': & $\begin{array}{l}20 \text { INDUSTRIAL LOTS } \\
\text { CONTAINING } 25,000 \\
\text { SQUARE FODT BLOGS } \\
\text { BUILDOUT BY } 2000\end{array}$ & $\begin{array}{l}\text { \$30 PER SQUARE FOOT } \\
\text { FOR HAREHDUSE SPACE }\end{array}$ & $\begin{array}{l}\$ 9.70 / \$ 1000 \\
\text { ASSESSED VALUE }\end{array}$ & $\begin{array}{l}\text { 90X WAREHOUSING } \\
\partial 1.25 \text { EMP/1000 SF } \\
10 x \text { OFFICE SPACE } \\
2.7 \text { EMP/1000 SF }\end{array}$ & $\begin{array}{l}\text { YAREHOUSE UAGE } \\
\text { BASED ON SIC 50-51 } \\
\$ 19,923 \text { PER YEAR } \\
\text { OFFICE WAGE } \\
\text { BASED ON SIC } 70-89 \\
\$ 14,304 \text { PER YEAR }\end{array}$ \\
\hline OCEAN SPRAY: & $\begin{array}{l}\text { 100\% OFFICE SPACE } \\
\text { BUILDOUT BY } 1995\end{array}$ & $\begin{array}{l}\$ 57.60 \text { PER SQ. FT. } \\
\text { FOR OFFICE SPACE }\end{array}$ & $\begin{array}{l}\$ 9.70 / \$ 1000 \\
\text { ASSESSED VALLEE }\end{array}$ & $\begin{array}{l}\text { ALL DFFICE SPACE } \\
\partial 4.7 \text { EMP } / 1000 \mathrm{SF}\end{array}$ & $\begin{array}{l}\text { BASED ON OCEAN SPRAY } \\
\text { ESTIMATES BY JOE }\end{array}$ \\
\hline GREAT PONDS: & $\begin{array}{l}\text { 93\% HAREHOUSING } \\
\text { 7\% MARUFACTURING } \\
\text { BUILDOUT BY } 2005\end{array}$ & $\begin{array}{l}\text { S3O PER SQUARE FOOT } \\
\text { FOR HAREHOUSE SPACE }\end{array}$ & $\begin{array}{l}19.70 / 1000 \\
\text { ASSESSED VALUE }\end{array}$ & $\begin{array}{l}93 \% \text { HAREHOUSING } \\
\partial 1.25 \text { EMP/1000 SF } \\
7 \% \text { MANUFACTURING } \\
\partial 1.7 \text { EMP/1000 SF }\end{array}$ & $\begin{array}{l}\text { WAREHOUSE UAGE } \\
\text { BASED ON SIC 5O-51 } \\
\$ 19,923 \text { PER YEAR } \\
\text { MANUFACTURINE } \\
\text { BASED ON SIC } 39 \\
\$ 20,253 \text { PER YEAR }\end{array}$ \\
\hline RIVERSIDE PAFR: & $\begin{array}{l}\text { 65\% HAREHOUSING } \\
\text { 25\% WANUFACTURING } \\
\text { 10\% OFFICE } \\
\text { BUILDOUT BY } 1995\end{array}$ & $\begin{array}{l}\text { \$30 PER SQUARE FOOT } \\
\text { FOR HAREHOUSE SPACE } \\
\$ 33.70 \text { PER SQ. FT. } \\
\text { FOR MANUFACTURING } \\
\$ 57.60 \text { PER SQ. FT. } \\
\text { FOR OFFICE SPACE }\end{array}$ & $\begin{array}{l}\$ 9.70 / \$ 1000 \\
\text { ASSESSED VALLE }\end{array}$ & $\begin{array}{l}\text { 65\% HAREHOUSING } \\
\partial 1.25 \text { EMP/1000 SF } \\
25 \text { KANUFACTURING } \\
\partial 1.7 \text { EMP/1000 SF } \\
10 \% \text { OFFICE SPACE } \\
\partial 4.7 \text { ERP/1000 SF }\end{array}$ & $\begin{array}{l}\text { WAREHOUSE HAGE } \\
\text { BASED ON SIC 50-51 } \\
\$ 19,923 \text { PER YEAR } \\
\text { MANUFACTUKING } \\
\text { BASED ON SIC } 39 \\
\text { \$20,253 PER YEAR } \\
1 / 2 \text { OFFICE } \\
\text { BASED ON SIC } 60-67 \\
1 / 2 \text { OFFICE } \\
\text { BASED ON SIC } 70-89\end{array}$ \\
\hline $\begin{array}{c}\text { Sources: } \\
\text { । }\end{array}$ & $\begin{array}{l}\text { DISCUSSIONS WITH } \\
\text { INDIVIDUAL OWNERS }\end{array}$ & $\begin{array}{l}\text { MEANS BUILDING } \\
\text { COST DATA (1986) }\end{array}$ & TOHN ASSESSORS & $\begin{array}{l}\text { INSTITUTE OF } \\
\text { TRAFFIC ENGINEERS } \\
\text { ITE, } 1985 \text { REPORT }\end{array}$ & $\begin{array}{l}\text { STATE DIVISION OF } \\
\text { EMPLOYMENT SECURITIES } \\
\text { 1986, WEH BEDFORD } \\
\text { SMSA ESTIMATES }\end{array}$ \\
\hline
\end{tabular}


TABLE 3

LÁKEVILLE INDLSTRIALL PARKS

FIVE YEAF PROJECTIONS

\begin{tabular}{|c|c|c|c|c|}
\hline \multicolumn{5}{|l|}{ Үеат 1990} \\
\hline & FLOOR AREA & TAXES & EMPLOYMENT & WAGES \\
\hline LAKEPORT & 100,000 & 34,300 & 160 & $3,097,776$ \\
\hline OCEAN SPRÁY & 150,000 & 87,896 & 360 & $7,380,000$ \\
\hline GREAT PONDS & 531,000 & 159,721 & 655 & $13,049,565$ \\
\hline RiVERSIDE & 200,000 & 71,269 & 267 & $5,319,441$ \\
\hline TOTAL & 981,000 & 353,186 & 1,442 & $28,846,782$ \\
\hline \multicolumn{5}{|l|}{ Year 1995} \\
\hline & FLOOR AREA & TAXES & EHPLOYHENT & UAGES \\
\hline LAKEPORT & 250,000 & 77,950 & 399 & $7,720,239$ \\
\hline OCEAN SPRAY & 310,000 & 177,291 & 610 & $14,115,000$ \\
\hline GREAT PONDS & $1,203,000$ & 355,273 & 1,406 & $28,003,022$ \\
\hline RIVERSIDE & 750,000 & 231,319 & 1,281 & $25,085,971$ \\
\hline TOTAL & $2,513,000$ & 841,834 & 3,695 & $74,924,232$ \\
\hline \multicolumn{5}{|l|}{ Year 2000} \\
\hline & FLOOR AREA & TAXES & EMPLOYMENT & MAGES \\
\hline LAKEPOKT & 500,000 & 150,700 & 798 & $15,440,477$ \\
\hline OCEAN SPRAY & 310,000 & 177,291 & 930 & $21,525,000$ \\
\hline GREAT POMDS & $1,846,000$ & 542,386 & 2,191 & $43,653,783$ \\
\hline RIVERSIDE & 750,000 & 231,319 & 1,281 & $25,085,971$ \\
\hline TOTAL & $3,406,000$ & $1,101,697$ & 5,199 & $105,705,231$ \\
\hline \multicolumn{5}{|l|}{ Veat 2005} \\
\hline & FLOOR AREA & TAXES & EMPLOYMENT & UAGES \\
\hline LAKEPQRT & 500,000 & 150,700 & 798 & $15,440,477$ \\
\hline OCEAN SPFAY & 310,000 & 177,291 & 930 & $21,525,000$ \\
\hline GREAT POHDS & $2,181,000$ & 639,871 & 2,571 & $51,224,523$ \\
\hline RIVERSIDE & 750,000 & 231,319 & 1,281 & $25,085,971$ \\
\hline TOTAL & $3,741,000$ & $1,199,182$ & 5,5791 & $113,275,971$ \\
\hline \multicolumn{5}{|c|}{ 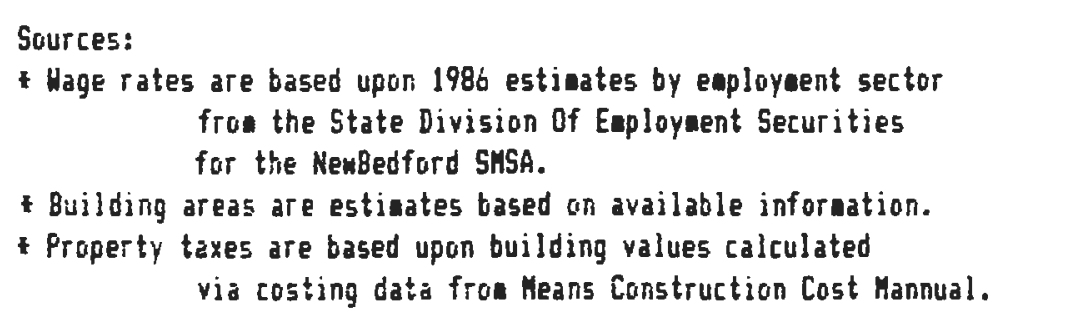 } \\
\hline
\end{tabular}


Secondary employment is the employment caused by the increase in demand resulting from the incoming industries and their personnel. This is made up of new businesses being established and existing businesses expanding in several areas: businesses that supply raw materials to the primary employers, businesses that provide services (janitorial, accounting, etc.) to the primary employer, and businesses that provide services (convenience stores, restaurants, etc.) to the new employees.

As with direct employment, secondary employment is calculated using national multipliers based upon the number of primary employees created by the developments and the population of the affected community. In this case, a multiplier of 0.4 was used, or for every 10 direct employees, there would be 4 indirect employees within the community. This calculation standard is based on the Edward Ullman and Michael Dacey study on The Minimum Requirements Approach to the Drban Economic Base."

Table 4 presents the summary of the employment projections, direct and secondary, for the four developments. Tables 5 , 6, 7 and 8 are the emplojment projections for each project, including income and secondary employment for the five year 
periods.

As can be seen from the tables, there $1 \mathrm{~s}$ going to be an Increase in total employment of 2,019 employees in 1990 , 5,173 by $1995,7,279$ by 2000 , and 7,811 by the year 2005 . The breakdown of the secondary employment by industrial categories will be presented in the subsection on land use 1mpacts (subsection D).

Tables 5 through 8 also indlcate the total incomes generated by the direct employment of each development. Tables 6, 7 and 8 use estimates as to the percent of employment in each SIC sector at the New Bedford SMSA wage rate, while Table 5 uses detalled estimates obtalned from the Ocean Spray Corporation directly; thus the desegregation into low, moderate and high categories (see Table 2 for assumptions). 
TABLE 4

EMPLDYMENT INCREASE

FIVE YEAR SUMMARY

\begin{tabular}{|c|c|}
\hline 1990 & \\
\hline DIRECT EMPLOYHENT & 1442 \\
\hline INDIRECT ENPLOYMENT & 577 \\
\hline TOTAL EMPLOYMENT & 2019 \\
\hline 1995 & \\
\hline DIRECT EMPLOYMENT & 3695 \\
\hline INDIRECT EMPLOYMENT & 1478 \\
\hline TOTAL EMPLOYMENT & 5173 \\
\hline
\end{tabular}

\begin{tabular}{|c|c|}
\hline \multicolumn{2}{|l|}{2000} \\
\hline DIRECT EMPLOYMENT & 5199 \\
\hline INDIRECT EMPLOYMENT & 2080 \\
\hline TOTAL EMPLOYMENT & 7279 \\
\hline 2005 & \\
\hline DIRECT EMPLOYMENT & 5579 \\
\hline INDIRECT EMPLOYMENT & 2232 \\
\hline TOTAL EMPLOYMENT & 7811 \\
\hline
\end{tabular}

Source: Canter, 'lepact of Grouth", 1986; Individual, EIS Reports. 
TABLE 5

EMPLOYMENT AND INCOME PROJECTIONS FOR

OCEAN SPGAY CORPORATE HEADQULARTERS

\begin{tabular}{|c|c|c|c|c|c|c|c|c|c|}
\hline YEAR & $\begin{array}{l}1 \\
\text { LOH }\end{array}$ & $\begin{array}{l}\text { OF JOBS } \\
\text { INCONE } \\
\text { MODERATE }\end{array}$ & HISH & $\begin{array}{l}\text { DIRECT } \\
\text { EMPLOYMENT }\end{array}$ & LOH & $\begin{array}{l}\text { - INCOME } \\
\text { MODEFATE }\end{array}$ & $\begin{array}{r}----1 \\
H I G H\end{array}$ & $\begin{array}{l}\text { INCOME } \\
\text { TOTAL }\end{array}$ & $\begin{array}{l}\text { SECONDARY } \\
\text { EMPLOYMENT }\end{array}$ \\
\hline 1990 & 90 & 234 & 36 & 360 & 15,000 & 20,000 & 37,500 & $7,380,000$ & 144 \\
\hline 1995 & 163 & 291 & 156 & 610 & 15,000 & 20,000 & 37,500 & $14,115,000$ & 244 \\
\hline 2000 & 248 & 444 & 238 & 930 & 15,000 & 20,000 & 37,500 & $21,525,000$ & 372 \\
\hline 005 & 248 & 444 & 238 & 930 & 15,000 & 20,000 & 37,500 & $21,525,000$ & 372 \\
\hline
\end{tabular}

Sources: Ocean Spray EIS, 1985;

Canter, "I epart of Erouth", 1986.

TABLE 6

EMPLOYMENT AND IMCOME PROJECTIONS FOR

LAKEPOFT INDUSTRIAL FAFK:

\begin{tabular}{lcccc} 
YEAR & $\begin{array}{c}\text { BUILOING } \\
\text { AREA }\end{array}$ & $\begin{array}{c}\text { DIRECT } \\
\text { ERPLOYMENT }\end{array}$ & $\begin{array}{l}\text { INCOME } \\
\text { TOTAL }\end{array}$ & $\begin{array}{c}\text { SECONDARY } \\
\text { EMPLOYMENT }\end{array}$ \\
\hline 1990 & 100,000 & 160 & $3,097,776$ & 64
\end{tabular}

$1995 \quad 250,000 \quad 399 \quad 7,720,239 \quad 160$

\begin{tabular}{|c|c|c|c|c|}
\hline 2000 & 500,000 & 798 & $15,440,477$ & 319 \\
\hline 2005 & 500,000 & 798 & $15,440,477$ & 319 \\
\hline
\end{tabular}

Sources: Lakeport Park EIS, 1986

Canter, "Inpart of Grouth", 1986. 
TABLE 7

ERPLOYMENT AND INCOHE PROJECTIONS FOR

GREAT PONDS INDUSTRIAL PAE:

\begin{tabular}{|c|c|c|c|c|c|}
\hline YEAR & $\begin{array}{c}\text { COMPANY } \\
\text { MAME }\end{array}$ & $\begin{array}{l}\text { BUILDING } \\
\text { AREA }\end{array}$ & $\begin{array}{r}\text { DIRECT } \\
\text { EMPLOYMENT }\end{array}$ & $\begin{array}{l}\text { INCOME } \\
\text { TOTAL }\end{array}$ & $\begin{array}{l}\text { SECONDARY } \\
\text { EMPLOYMENT }\end{array}$ \\
\hline 1990 & $\begin{array}{l}\text { TALBOT'S } \\
\text { RIX-DUKK } \\
\text { THOMP BOX } \\
\text { DUNDAS } \\
\text { HEW BLDGS }\end{array}$ & $\begin{array}{r}360,000 \\
100,000 \\
40,000 \\
31,000 \\
0\end{array}$ & $\begin{array}{r}400 \\
200 \\
40 \\
15 \\
0\end{array}$ & $\begin{array}{r}7,969,200 \\
3,984,600 \\
796,920 \\
298,845 \\
0\end{array}$ & \\
\hline TOTAL & & 531,000 & 655 & $13,049,565$ & 262 \\
\hline 1995 & $\begin{array}{l}\text { TALBOT'S } \\
\text { RIX-DUNN } \\
\text { THDMP BOX } \\
\text { DUNDAS } \\
\text { HEH BLDGS }\end{array}$ & $\begin{array}{r}627,000 \\
100,000 \\
40,000 \\
131,000 \\
305,000 \\
1,203,000\end{array}$ & $\begin{array}{r}700 \\
200 \\
40 \\
50 \\
416 \\
1,406\end{array}$ & $\begin{array}{r}13,946,100 \\
3,984,600 \\
796,920 \\
996,150 \\
8,313,536 \\
28,037,306\end{array}$ & 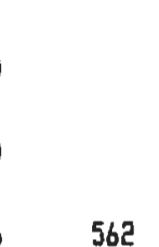 \\
\hline TOTAL & $\begin{array}{l}\text { TALBOT'S } \\
\text { RIX-DUNA } \\
\text { THOKP BOX } \\
\text { DUNDAS } \\
\text { NEH ELDGS }\end{array}$ & $\begin{array}{r}965,000 \\
100,000 \\
40,000 \\
131,000 \\
610,000 \\
1,846,000\end{array}$ & $\begin{array}{r}1,070 \\
200 \\
40 \\
50 \\
831 \\
2,191\end{array}$ & $\begin{array}{r}21,317,610 \\
3,984,600 \\
796,920 \\
996,150 \\
16,627,071 \\
43,722,351\end{array}$ & 876 \\
\hline TOTAL & $\begin{array}{l}\text { TALBOT'S } \\
\text { RIX-DUNK } \\
\text { THOHF BOX } \\
\text { DUNDAS } \\
\text { NEH FLOGS }\end{array}$ & $\begin{array}{r}1,300,000 \\
100,000 \\
40,000 \\
131,000 \\
610,000 \\
2,181,000\end{array}$ & $\begin{array}{r}1,450 \\
200 \\
40 \\
50 \\
831 \\
2,571\end{array}$ & $\begin{array}{r}28,888,350 \\
3,984,600 \\
796,920 \\
996,150 \\
16,627,071 \\
51,293,091\end{array}$ & 1,028 \\
\hline
\end{tabular}

Sourtes: Great Fonds EIS, 1986; Lakeville Deveiupnent Corp, 1988;

Talbot's Managenent, 1989; Canter, "lapact of Grouth", 1986. 
TAELE 8

EMPLOYMENT AND INCOME PROJECTIONS FOR

RIVERSIOE PARK

\begin{tabular}{|c|c|c|c|c|}
\hline YEAR & $\begin{array}{l}\text { BUILDINE } \\
\text { AREA }\end{array}$ & $\begin{array}{r}\text { DIRECT } \\
\text { EMPLOYMENT }\end{array}$ & $\begin{array}{l}\text { INCOME } \\
\text { TOTAL }\end{array}$ & $\begin{array}{l}\text { SECONDARY } \\
\text { EMPLOYMENT }\end{array}$ \\
\hline 1990 & 200,000 & 267 & $5,319,441$ & 107 \\
\hline 1995 & 750,000 & 1,281 & $25,085,971$ & 512 \\
\hline 2000 & 750,000 & $1,28 !$ & $25,085,971$ & 512 \\
\hline 2005 & 750,000 & 1,291 & $25,085,971$ & 512 \\
\hline
\end{tabular}

Sources: Riverside Park E1S, 1985; Middleborough Corp. Managesent, 1988; Canter, "Inpact of Growth", 1986. 


\section{Comparative Analysis}

In order to obtain a basis for the projected growth of Lakeville, a comparison is made to three towns that had experienced a major increase in their industrial development between 1970 and 1980. The towns examined are North Attleborough, Bridgewater and Dedham. North Attleborough and Bridgewater are chosen due to their locational similarities with Lakeville. Dedham is chosen because it is located along the original Boston ring road, Rte 128, which is becoming replaced by Rte 495 .

Table 9 displays the comparison towns. The column entitled "g of Total Employment" Indicates the percentage of the total employment in the municipality that is in the each sector. In the Finance, Insurance \& Real Estate sector, Lakeville is only slightly below the other towns. The contract Construction sector is almost double the other towns, on average, and reflects the large amount of development that is currently taking place in Lakeville. Lakeville's Manufacturing sector is significantly below that of the other towns, due to the rural town's character. The Wholesale \& Retall Trade sector of Lakeville is greatly below that of both Dedham and Bridgewater, although it is larger than North Attleborough's. And finally the Service Employment is at least double that of the other towns. 
The usefulness of this comparative analysis is that it

indicates the employment sectors which are likely to change

as a result of the industrial development. Therefore, it is

expected that the employment distribution in Lakeville will,

over time, resemble that of the towns compared. For example,

it is likely that employment in the Wholesale and Retail

Trade sector will represent a much larger portion of the

total employment in the future. This supports the estimate

of an increase in secondary employment, although it does not

Indicate the magnitude of that increase.

60 
TABLE ?

COMPARITIVE ANALYSIS OF

SOCIO-ECOMOMIC CHARACTERISTICS
NORTH ATTLEBOROUGH
BRIDGEHATER
DEDHAN
LAKEUILLE

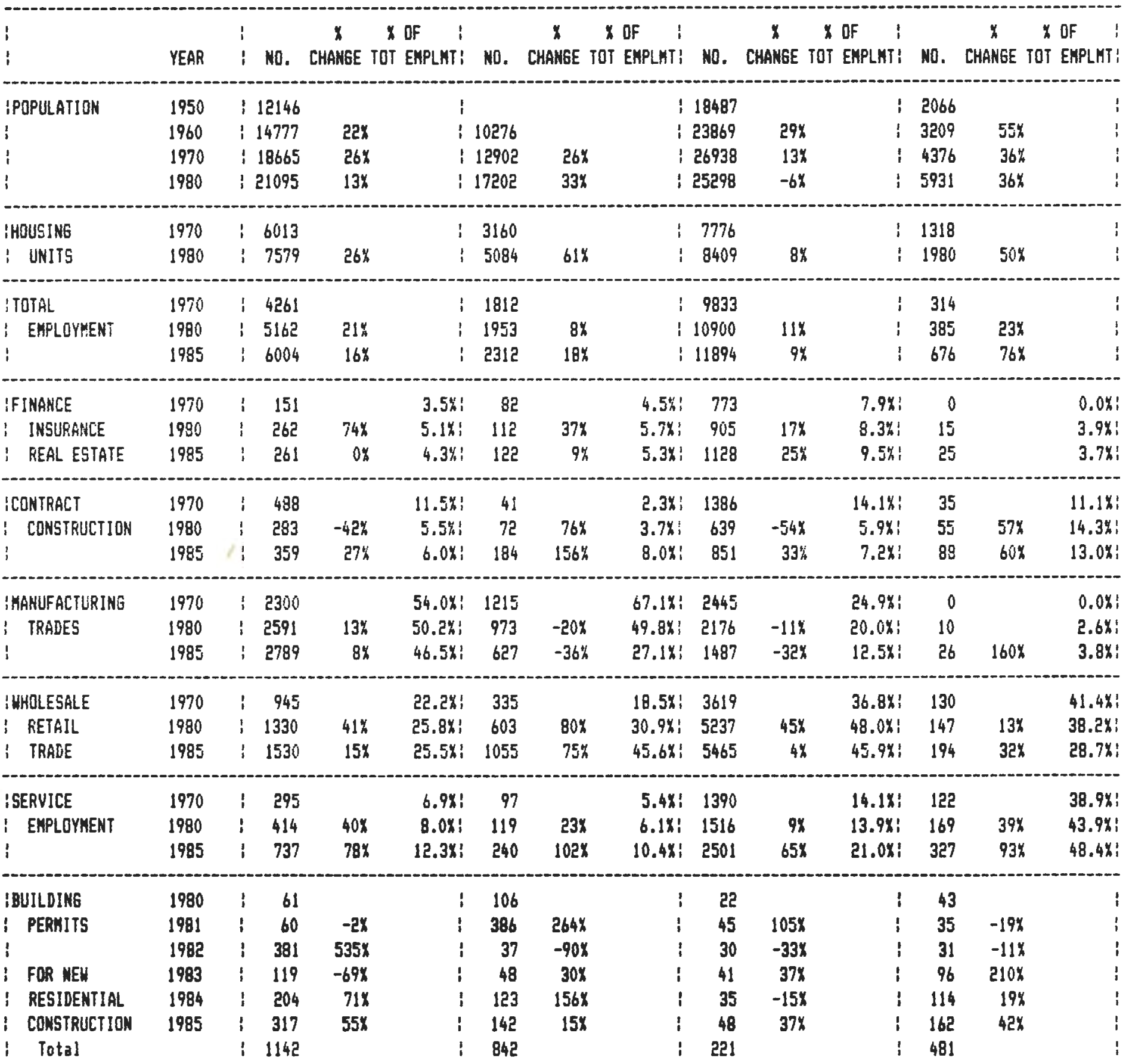

Sources: U.S. Census, 1950, '60, '70, 1980; Annusl Building Perait Data, 1980-1985; Hassachusetts Division of Employment Securities, 1986 report. 


\section{FISCAL IMPACTS}

The following is an analysis of municipal costs of the four developments by use of the employment anticipation method. Th1s method, developed by the Center for Urban Policy Research at Rutgers University, predicts a change in municipal costs based on an anticipated change in local commercial and industrial employment levels and per capita municipal costs.

The principal areas of Impact are on public safety, public works and statutory and unclassified expenses, and insurance costs applicable to other town departments. Statutory and unclassifled expenses also include a number of miscellaneous expenses such as unpaid bills from prior years and the Plymouth County Assessment. The estimated cost to Lakerille, as displayed in Table 10, ranges from $\$ 107,187$ in 1990 to $\$ 414,699$ in the year 2005 .

Revenues from the projects are estimated based on the estimated real property value of the land and buildings in projects and the current Lakeville real property tax rate. It 1 s estimated (based on calculations contained in Table 3 ) that real property tax revenues from all four developments w11l range from $\$ 353,186$ in 1990 to $\$ 1,199,182$ in 2005 . 
TABLE 10

PROJECTED EXPENDITURES BASED ON

EMPLOYMENT ANTICIPATION METHOD

\begin{tabular}{|c|c|c|c|c|}
\hline \multirow{2}{*}{$\begin{array}{l}\text { Expenditure } \\
\text { Category }\end{array}$} & \multicolumn{4}{|c|}{ YEAR } \\
\hline & 1990 & 1995 & 2000 & 2005 \\
\hline Genearl Governaent & $\$ 1,243$ & $\$ 3,185$ & $\$ 4,482$ & $\$ 4,810$ \\
\hline Public Safety & $\$ 25,482$ & $\$ 65,295$ & $\$ 91,872$ & $\$ 98,587$ \\
\hline DPH Highway & $\$ 21,223$ & $\$ 54,381$ & $\$ 76,516$ & $\$ 82,109$ \\
\hline $\begin{array}{l}\text { Board of Health } \\
\text { (land fill) }\end{array}$ & $\$ 3,229$ & $\$ 8,275$ & $\$ 11,643$ & $\$ 12,494$ \\
\hline Heal th \& Melfare & $\$ 4,119$ & $\$ 10,554$ & $\$ 14,850$ & $\$ 15,936$ \\
\hline Recreation \& Culture & $\$ 12,256$ & $\$ 31,405$ & $\$ 44,188$ & $\$ 47,417$ \\
\hline Statutory \& Unclassified & $\$ 39,201$ & $\$ 100,450$ & $\$ 141,337$ & $\$ 151,668$ \\
\hline Debt Service & $\$ 434$ & $\$ 1,112$ & $\$ 1,564$ & $\$ 1,679$ \\
\hline TOTAL EXPENDITURES & $\$ 107,187$ & $\$ 274,657$ & $\$ 386,452$ & $\$ 414,699$ \\
\hline $\begin{array}{l}\text { PROJECTED REVENUES } \\
\text { (fron Table } 3 \text { ) }\end{array}$ & $\$ 353,186$ & $\$ 941,834$ & $\$ 1,101,697$ & $\$ 1,199,182$ \\
\hline & & & $=$ & \\
\hline MET REVENUE & $\$ 245,999$ & $\$ 567,177$ & $\$ 715,245$ & $\$ 784,483$ \\
\hline
\end{tabular}

Sources: Burchell and Listokin, Fiscal Inpact Handbook, 1983; Lakeville 1986 Annual Repurt.

The bottom line of Table 10 predicts the net revenue based upon the estimated increase to real property tax, minus the estimated increases in municipal costs. As can be observed, it is estimated that Lakeville will obtain a net gain from the four developments of $\$ 245,999$ in 1990 , and $\$ 784,483$ in 2005

In addition to the real property tax on land and buildings, a small anount of revenue will be raised from other sources. Idditional revenue will be raised via personal property tax on equipment for non-incorporated businesses, real property taxes on the value of utility lines (principally telephone 
lines), and the motor vehicle excise tax on all registered vehicles garaged in Lakeville. Revenues will also be raised from a varlety of miscellaneous sources such as fees for permits (building, wirling, etc.), police extra duty charges and parking tickets. 


\section{HOUSING AND POPULATION INCREASE}

\section{Baseline}

In order to determine the impacts of the four developments on Lakeville over the next fifteen plus years, it is necessary to project the future changes in the town's population and housing without the developments. This was achieved by using a modified cohort survival population projection technique.

The modified cohort survival technique uses the population trends from the 1970 and 1980 Federal Census and the 1985 State Census as well as the recent trend of building permits (obtained annually from the Town through 1986) and forecasts those trends into the future. In this case, a simple IInear regression of the building permit data was used (from 1970 through 1986) to estimate future growth while normalizing the extremely high rate of building activity in Lakeville over the last four years. The population projection is shown in Table 11 as the Baseline Trend Growth.

The Baseline Trend Growth indicates that the population will reach 13,986 by 2005 . The total number of occupled housing units will be 4,995. Although recent sales data indicates that Lakeville's vacancy rate is around 28 , the housing statistics used in this case are from the 1980 Federal Census, which indicated a $4.5 \%$ vacancy rate. For this 
TAELE 11

ESTIMATED HOUSIHE IMPACTS OH LAKEVILLE DUE TO INDUSTRIAL DEVELOPMENT

BASED ON NATIONAL AVERAGES

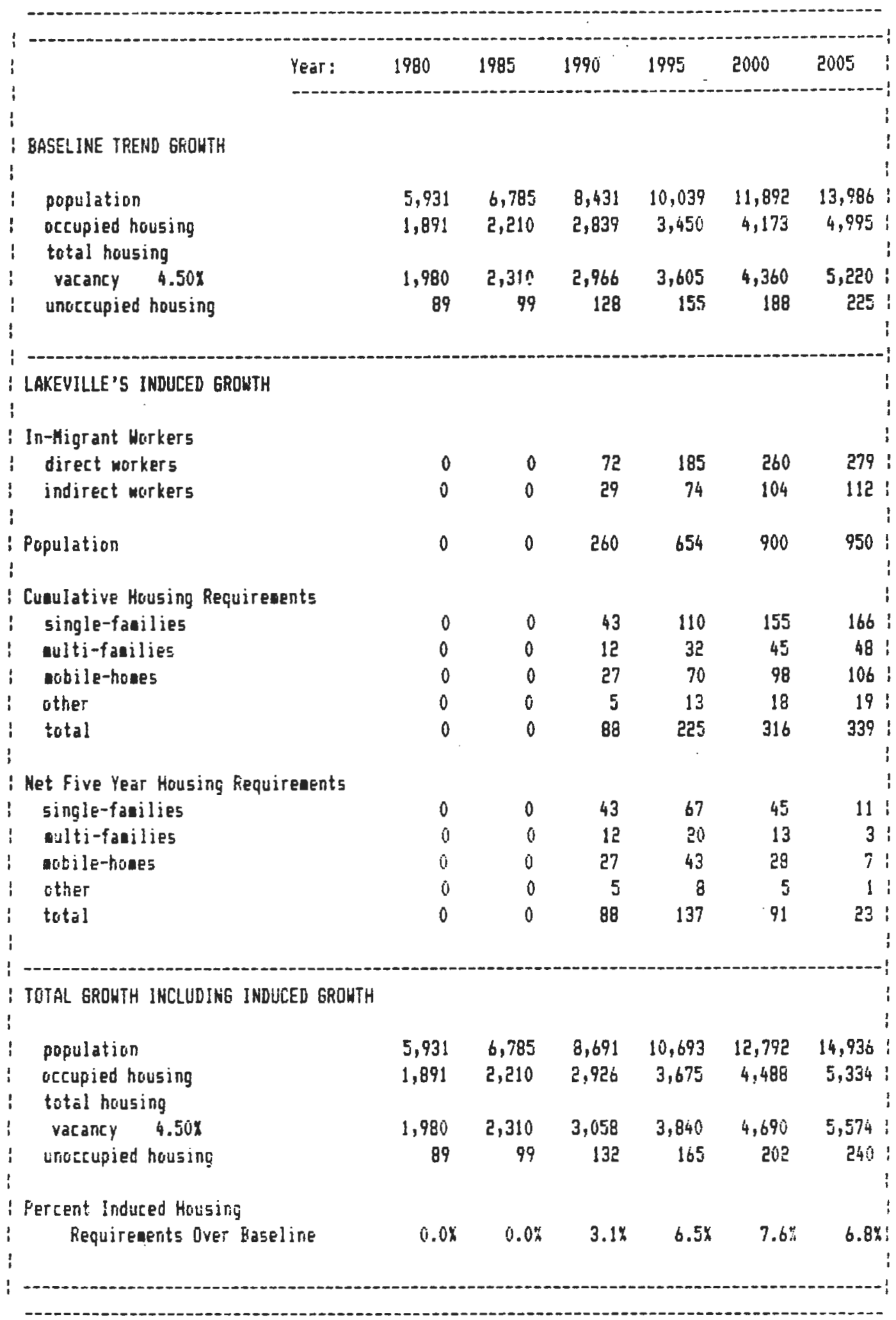

Sources: Fopulation projections based on SPFECD's 1989 Cohort Survival frojection;

Mutilpliers used, nere obtained from the baak "Iapact of Grokth", Lewis Publishers, ine.

- Al! Multap!iers are listed in Appendex. 
reason, we generally refer to the total occupled housing units rather than the total housing units.

It should be noted that the individual figures in the following tables may not sum to the exact totals. This is a result of the rounding and not an error in the addition.

\section{Region of Influence}

The size of the four developments and their proximity to Route 495 made it necessary to look at the "region of influencen (ROI) in order to determine the direct impacts on Lakeville (Map 14). The region of Influence was arrived at by using the average Massachusetts mean travel time to work, 20 minutes, and the actual driving distance at a reasonable speed to the limits of that travel time. It was assumed that fifteen minutes would be the maximum time spent on a major highway (Routes $495,24 \& 140$ ) in order to allow time to navigate from the interchange to a residential location.

Lakeville's total land area makes up approximately 118 of the entire region of influence. This would indicate that approximately 118 of the mean of the work force would want to live in Lakerille. A $50 \%$ weight was placed on this ractor to reflect those employees who would want to live beyond that mean travel time, and thus Lakeville would contain 5.58 of the total work force generated by the four developments. 


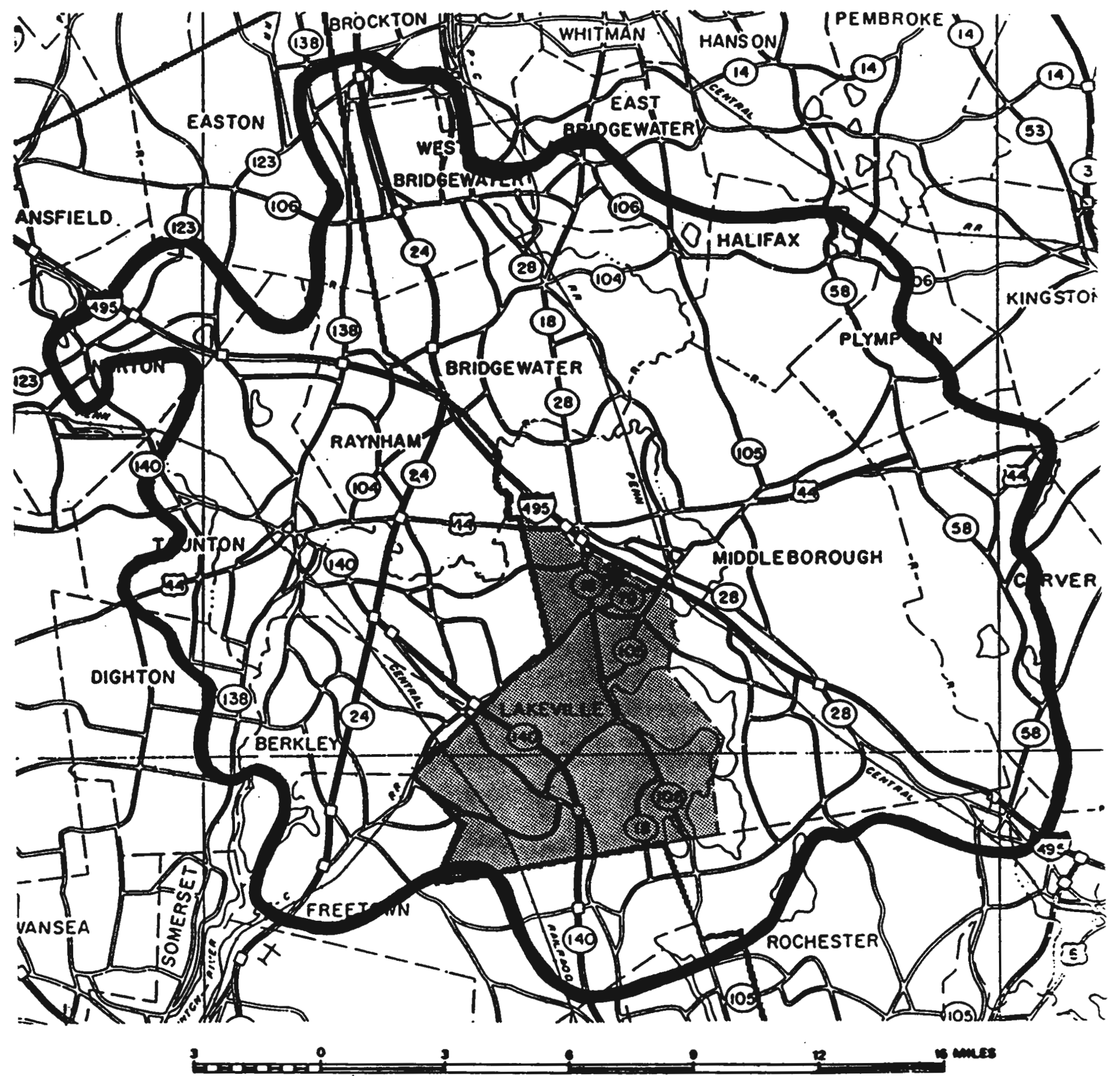

MAP 14

AREA MAP CORRESPONDING TO

20 MINUTE TRAVEL TIME TO WORK

FROM CENTRAL LOCATION 
The estimate of the resident employees is on an area basis and does not reflect the greater supply of avallable affordable housing units in the surrounding towns. 


\section{Induced Housing Demand and Population Increase}

The "Lakevilie's Induced Growth" section of Table 11 relates the in-migration of employees to the number and preference of housing units needed by the workers. These figures are derived from national standards which allot different quantities of workers per household and workers families per household in different housing types (see Appendix for multipliers). Although these housing types are unarailable under present zoning, this table still reflects the demand for these housing types which will be created by the four developments. This will be discussed in further detail in the section on land use impacts (subsection D).

The "Cumulative Housing Requirements" section is the total housing units required to house the workers who wish to live in Lakevilie. The "Net Five Year Housing Requirements" is the difference between the cumulative total for that period and the cumulative total for the preceding period. Thus, it is the amount of housing required from one period to the next. For single family homes in 1995 the net requirement is 67, (1e. 110 minus 43 ).

The section of Table 11 entitled "Total Growth" 18 the baseline population projection plus the expected number of new employees and their families. These projections for total population are also calculated using the multipliers 
for the number of workers per household and the number of family members per worker. This indicates that by the year 2005 , there w1ll be a total population of 14,936 and an occupled housing supply of 5,334 units within Lakeville. Thus an increase of 950 persons, or $6.8 \%$ over the baseline projection, is expected as a result of the four developments.

Table 12 is 1dentical to Table 11 except for the multipliers used to calculate housing demand. Table 12 applies the averages obtalned from the "Outside SMSA" category for Massachusetts from the 1980 Federal Census. The results of this change was a 399 increase in single-family housing demand and a $93 \%$ decrease in mobile-homes. This lowers the total housing demand by 9 units. The induced population is decreased by 25 persons. (Table 12 is for comparison purpose only, it displays the relationship of population to housing type and zoning).

An important element of these housing and population projections is that they are based upon one worker per family household. Thus, it does not take into account the families where both the husband and wife work in the same industry or where the husband or wife works in a secondary industry. Therefore, the estimate of population and housing is likely to be above the actual increase. 
TÁBLE 12

ESTIMATED HOUSING IMPACTS ON LAKEVILLE DUE TO INDUSTHIAL DEVELGPMENT GASED ON MGSSACHUSETTS (OUTSIDE SHSA'S) AVERAGE

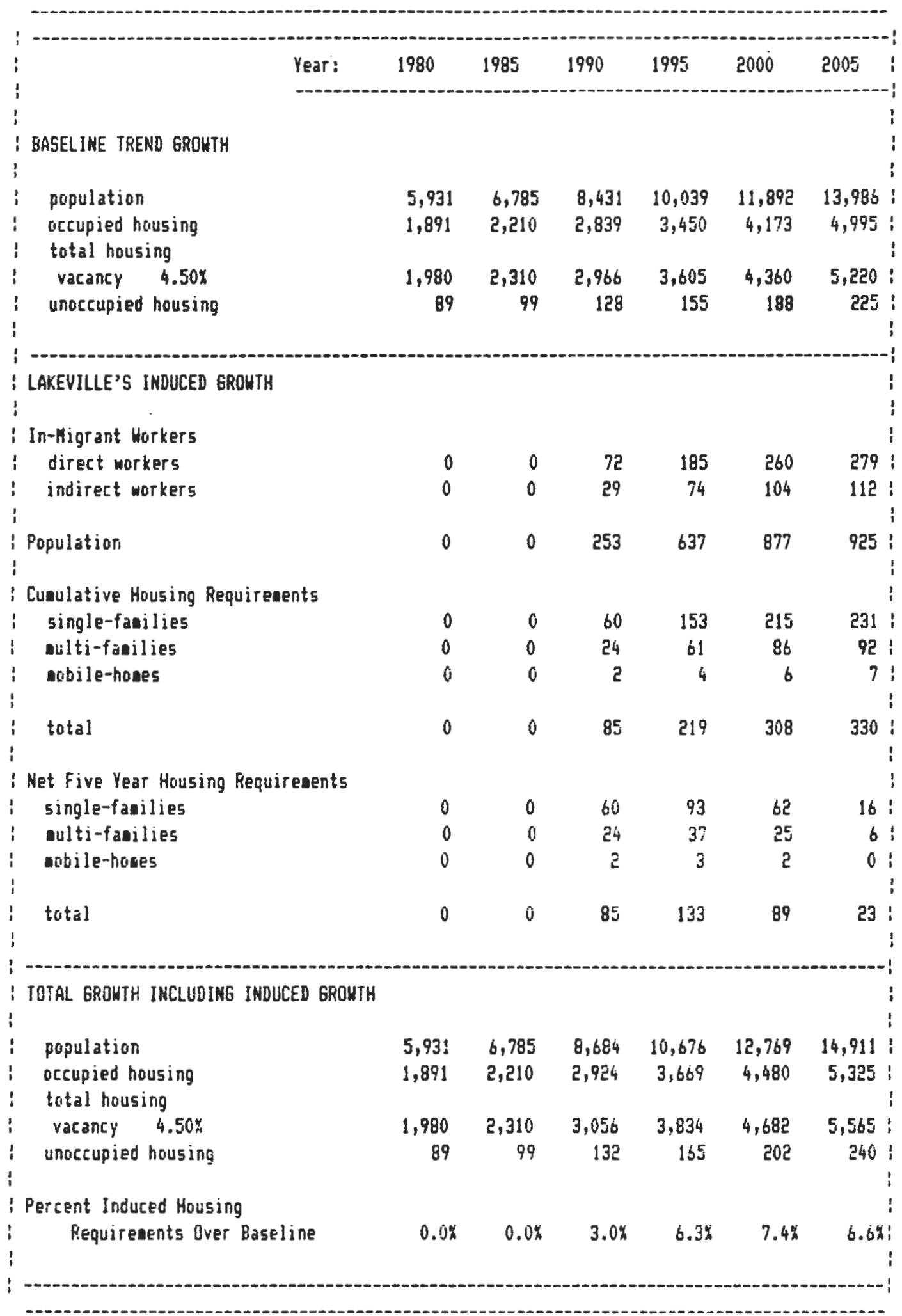

Saurces: Papulation projections based on SRFEDD's 1988 cohort Survival Projectioni Mutilfliers used mere obtained from the boak "I Inact of Growth", Lemis Publishers, Inc. a All eultipliers are included in the Appendex. 
LAND USE IMPACTS

The following is an analysis of the projected land consumption as related to the four developments. The land consumption is separated into direct impacts resulting from the use of land for the four developments, the land needed for the housing demand caused by the influx of direct and secondary workers 1nto Lakeville, and secondary employment Impacts which attempts to project the amount of land required to provide for the secondary business spawned by the four developments.

\section{D1rect Impacts}

Lakeport, Ocean Spray, Great Ponds and Riverside projects account for an aggregate land area of 575 acres within Lakeville $(60$ acres of the Ocean Spray site are in Middleborough). ThIs figure includes the total land area for buildings, roadways, parking areas, landscaping and open space.

Of the total 575 acres, there are approximately 100 acres of wetlands, 40 acres of open water, 20 acres of bogs and 20 acres of floodplain all of which will remain virtualiy unaltered. The remainder of land to be developed is primarily open space and woodlands. 


\section{Land Consumed Related to Secondary Housing Impacts}

The land use impacts associated with the housing demand created by the four developments are addressed in Table 13, - Acres Required for Residential Development". This table estimates the impacts in terms of that land acreage which will be needed to provide housing for the total number of workers (both direct and secondary) assumed to settle in Lakeville. This estimate was discussed in the "Housing and Population Increasen section of this chapter (Table 11). Onder Lakeville's current zoning requirements, the cumulative impact of worker related housing demands within the Town by 2005 is projected to be 326 units, covering 523.6 acres of 1and. (see Table 13, Scenario 1)

If Lakevilie's zoning requirements are changed in the near future to allow mixed, multi-family housing and mobile homes, the housing related land use impact could be lessened. This possibility is reflected in Table 13, Scenario 2 , which presents alternative housing impacts based on national averages for housing demand. Under scenario 2 , a greater number of housing units is provided while saving approximately 115 acres of land. The final alternative, Scenario 3 , is based upon the recent Massachusetts patterns for housing demand. This shows that the total land acreage can be reduced by 99 acres. Therefore, changes in current zoning requirements could oreate less of an impact in 
TABLE 13

ALTERNATIVE ZOMING SCENARIOS

ACRES OF LAND REQUIRED FOR RESIDENTIAL DEVELOPMENT

(Based upon 5 k of total eaployment to locate in Lakeville)

\begin{tabular}{|c|c|c|c|c|c|c|c|c|c|c|}
\hline & Year: & 1990 & & 1995 & & 2000 & & 2005 & & ! \\
\hline LAKEVILLE PROJECTED HOUSING DEHAND & & & $\begin{array}{l}\text { LAND } \\
\text { ACRES }\end{array}$ & & $\begin{array}{l}\text { LAND } \\
\text { ACRES }\end{array}$ & & $\begin{array}{l}\text { LAND } \\
\text { ACRES }\end{array}$ & & $\begin{array}{l}\text { LAND } \\
\text { ACRES }\end{array}$ & : \\
\hline \multicolumn{11}{|l|}{ In-Migrant Horkers } \\
\hline direct workers & & 72 & & 185 & & 260 & & 279 & & ! \\
\hline indirect workers & & 29 & & 74 & & 104 & & 112 & & ! \\
\hline SCENARIO 1 & & HOUSING & & HOUSING & & HOUSING & & HOUSING & & i \\
\hline Current Zoning & & UNITS & & UNITS & & UNITS & & UNITS & & ; \\
\hline single-fasilies 1 uniti70,000 SF & & 84 & 135.3 & 216 & 346.8 & 303 & 487.5 & 326 & 523.6 & 1 \\
\hline \multicolumn{11}{|l|}{ SCENARIO 2} \\
\hline \multicolumn{11}{|l|}{ Zoning Changes (Watiunal Average) } \\
\hline single-fanilies 1 unit $/ 70,000 \mathrm{SF}$ & & 43 & 69.0 & 110 & 176.9 & 155 & 248.6 & 166 & 267.0 & 1 \\
\hline oulti-fanilies 2 units/ACRE & & 12 & 6.2 & 32 & 16.0 & 45 & 22.5 & 48 & 24.2 & : \\
\hline sobile-lioues $\quad 1$ unit/ACRE & & 27 & 27.3 & 70 & 70.1 & 98 & 98.5 & 106 & 105.8 & ! \\
\hline 2 units/ACRE & & 5 & 2.4 & 13 & 6.3 & 18 & 8.8 & 19 & 9.4 & : \\
\hline total & & 88 & 105.0 & 225 & 269.2 & 316 & 378.4 & 339 & 406.4 & $i$ \\
\hline \multicolumn{11}{|l|}{ SCENAR 103} \\
\hline \multicolumn{11}{|l|}{ Zoning Changes (Massachusetts Average) } \\
\hline single-fasilies 1 unit/70,000 SF & & 60 & 96.4 & 153 & 245.9 & 215 & 345.5 & 231 & 371.2 & : \\
\hline oulti-fasilies 2 units/ACRE & & 24 & 12.0 & 61 & 30.5 & 86 & 43.0 & 92 & 46.0 & 1 \\
\hline subile-huees & & 2 & 2.0 & 4 & 4.0 & 6 & 6.0 & 7 & 7.0 & i \\
\hline total & & 86 & 110 & 218 & 280 & 307 & 395 & 330 & 424 & 1 \\
\hline
\end{tabular}

* Scenario 1 is based on current local zoning.

+ Scenario 2 is based on national averages for housing deand (see Table 11).

* Scenario 3 is based on hassachusetts "Outside 5n5A" averages for housing deand (see Table 12).

Source: Mutilpliers used in this nodel were obtained froe the book "Inpact of Grawth", of Lewis Publishers, Inc. * All aultipliers are listed in Appendex. 
addressing projected housing needs.

\section{Secondary Employment Impacts}

The Inftial businesses, once established, have secondary land use impacts. They attract service oriented activities to serve the needs created within the park 1tself. The nature of secondary activities within a region will vary according to the diversity and needs of the principal businesses as well as the local or regional labor supply. As it is virtually impossible to predict the nature of the secondary activities, estimate of the occupations for secondary or indirect employment are based upon the most recent avallable employment trends in Plymouth County (1980 U.S. Census).

The number of secondary workers per occupation was derived by applying the percentages of employees per occupation in Plymouth County to the projected number of secondary workers (listed In Table 14, occupation, Plymouth County by Percentage"). These projections are listed in Table 14. According to the cumulative figure, secondary employment is projected to 1ncrease by 2,232 positions, within the entire region, by the year 2005 .

In order to determine the land acreage and square feet of bullding space required for the projected secondary workforce, the potential occupations presented in Table 15 
TABLE 14

OCCUFATIONS, FLYMOUTH COUNTY BY PERCENTAGE

FOR 1980

(total enplayed 175,768 )

\begin{tabular}{|c|c|c|c|c|c|c|c|c|c|c|c|}
\hline & & 1 & & 2 & & & 3 & 4 & & & \\
\hline & ADHIN & PROF/TECH & SALES & ADMIN/SUP & SERV & FARM & PPCLR & НACH/OP & TRANS & LABORS & TOTAL \\
\hline 1980 & $11.74 x$ & $16.39 \%$ & $10.45 \%$ & $17.77 \%$ & $13.71 \%$ & $1.10 \%$ & $13.28 \%$ & $8.81 \%$ & $3.04 \%$ & $3.71 \%$ & $1:$ \\
\hline
\end{tabular}

TABLE 15

PROJECTED SECONDAGY EMPLOYMENT BY OCCUPATION FOR LAKEVILLE

Tatal Employsent

\begin{tabular}{|c|c|c|c|c|c|c|c|c|c|c|c|}
\hline & ADHIN & PROF/TECH & SALES & ADHIN/SUP & SERV & FAFM & PPCER & $\mathrm{AACH} / \mathrm{OF}$ & TRANS & LABOAS & TOTAL \\
\hline 1990 & 68 & 95 & 60 & 103 & 79 & 6 & 77 & 51 & 18 & 21 & 577 \\
\hline$\$ 995$ & 174 & 242 & 155 & 263 & 203 & 16 & 196 & 130 & 45 & 55 & 1479 \\
\hline 2000 & 244 & 341 & 217 & 370 & 285 & 23 & 276 & 183 & 63 & 77 & 2080 \\
\hline 2005 & 262 & 366 & 233 & 397 & 306 & 24 & 296 & 197 & 68 & 83 & 2232 ! \\
\hline
\end{tabular}

TABLE 16

CUMULATIVE LANO USE IMPACT OF SECONGARY EMFLOYMENT

(in euployee square feet is eaployee actes)

\begin{tabular}{lrrrrrrrr} 
& \multicolumn{2}{c}{1990} & \multicolumn{2}{c}{1995} & \multicolumn{2}{c}{2000} & \multicolumn{2}{c}{2005} \\
& Sq Ft & Actes & Sq Ft & Actes & Sq Ft Actes & Sq Ft Actes \\
OFFICE & 86,023 & 50 & 220,350 & 128 & 310,100 & 180 & 332,762 & 193 \\
HAREHOUSE & 31,154 & 3 & 79,803 & 7 & 112,307 & 10 & 120,514 & 11 \\
INOUSTRIAL & 78,676 & 8 & 201,530 & 21 & 283,614 & 29 & 304,340 & 32 \\
TOTAL & 195,853 & 61 & 501,683 & 156 & 706,022 & 219 & 757,616 & 235
\end{tabular}

1 PROFESSIOMAL / TECHNICAL

2 ADHINISTRATIVE SUPPORT

3 PRECISION PRODUCT CRAFT \& REPAIR

4 MACHINE OPERATORS / ASSEMBLERS

Sources: U.S. Census 1980. Massachusetts Division of Employent Security, 1986 Report. Institute of Traffic Engineers, 1985. 
are categorized into: Office, Warehouse and Industrial services (see Table 16). The number of employees within each of these three categories were then multiplied by standards given by the Institute of Traffic Engineers, Trip Generation Manual to determine the amount of square feet of space and acres of land necessary to accomodate local industrial growth.

The cumulative land use impacts of secondary employment shows an increase of 757,616 square feet of building space and 235 acres of land within the region by the year 2005. It should be noted that these numbers are not necessarily indicative of one or more discrete planned industrial developments. Rather, these figures may represent additions to existing buildings, buildings on single lots, as well as new developments. Furthermore, it should be remembered that these figures are based upon the total bulldout of the four developments being with a primary industries rather than a secondary industries, an assumption which is sure to inflate the actual amount. 


\section{HOUSING AFFORDABILITY}

Housing affordability has become a major issue in

Massachusetts because housing market imbalances are now affecting households on all rungs of the economic ladder. Today's housing problems are the result of economic growth 1tself: prosperity means higher incomes and cheaper credit, and these two elements have led in the mid-1980's to a run on the housing stock within the state. Adding to this is the pent up demand from the years of high interest rates and pressure from an unusually large number of new households competing for homes and rental units. Within a span of thirty months beginning in 1984, a median-priced home in the Boston Metropolitan Area became the most expensive medianpriced home in the United States, affordable for only a small segment of Massachusetts households.

Lakeville is no exception to this tremendous increase in housing prices. According to the Multiple Listing Service, there are 89 housing units on the market in Lakeville, with an average asking price of $\$ 211,000$. The price ranges and units avaliable in Lakeville are listed in the first and second column of Table 17 . 
TABLE 17

LAKEVILLE HOUSING LIST PRICE AND IMCOME REQUIREMENTS

FOR BOTH 25\% AND 33\% OF ANHLLAL HOUSEHOLD INCOHE

(May 1988)

\begin{tabular}{lccc} 
PRICE & 25\% OF & $33 \%$ OF \\
& UNITS & ANMUAL INCOME & ANNUAL INCOME \\
\hline 754999 & 6 & 23,040 & 17,280 \\
$100000-149999$ & 6 & 33,600 & 25,200 \\
$150000-199999$ & 15 & 58,368 & 43,776 \\
$200000-249999$ & 27 & 67,200 & 50,400 \\
$250000-299999$ & 19 & 86,400 & 64,800 \\
$300000-349999$ & 8 & 105,600 & 79,200 \\
$350000-399999$ & 4 & 124,800 & 93,600 \\
$\$ 400000+$ & 3 & 144,000 & 108,000 \\
& 1 & 153,600 & 115,200
\end{tabular}

\#\#ssuaing a standard nortgage with $20 \%$ down at $11 \%$ interest rate on a 30 year note.

Source: Mew Bedford Multiple Listing Service, 1988.

The Increase in housing prices is being driven by the rising price of avallable land. Presently there are 14 buildable parcels listed in the Multiple Listing Service, ten for sale for between $\$ 75,000$ and $\$ 100,000$, three between $\$ 100,000$ and $\$ 200,000$ and one subdividable parcel for greater than $\$ 200,000$.

The cost of rental housing in Lakeville, when avallable, runs around $\$ 900$ to $\$ 1,100$ per month. The exception to this is the large supply of summer cottages which generaliy rent for between $\$ 700$ and $\$ 800$ per month. These are only cottages however, and would not be adequate for employee housing.

The sale price of housing in Lakeville is largely the same as surrounding rural communities; however, this is not true with 
the rental market. The main reason for the disparity in rental housing is the complete lack of apartment style housing in Lakeville.

Middleborough, for example, has a rental price for single family homes roughly the same as that of Lakeville. However, the apartment rental price differs due to the avallability. In Middleborough, the price of apartments with one bedroom are between $\$ 375$ and $\$ 425$ per month and the two bedroom units are between $\$ 500$ to $\$ 600$ per month. In Taunton, the rental prices, starting at around $\$ 300$ per month, varies widely due to the large supply.

The demand for different types of housing is going to increase as a result of the four developments; this was displayed in Table 11. However, even if this demand is not met under the present zoning, and those interested in the other forms of housing go elsewhere, the demand for single family houses is going to increase greatly in the lower price ranges.

The last two columns in Table 17 indicate the approximate family income needed to purchase units in these price ranges with 258 and $33 \%$ of a family's yearly earnings devoted to housing. Both $25 \%$ and 338 are considered by financing companies acceptable portions of family income contributable to housing expense. 
The type of jobs created by the developments, with exception of Ocean Spray, will have large percentages of low to moderate income employment. This will create a demand for the lower priced units which may increase the price of these units and decrease their availability.

Table 18 indicates the approximate number of the direct employees with incomes within the given ranges. Comparing the number of jobs in the different income ranges to the income requirements from Table 17, it is easy to see the inability of new employees to afford the average selling price of housing in Lakerille. It should be noted that Table 18 does not take into account any secondary income resulting from a working spouse, which in Massachusetts in 1980 was around 53\%. Nor does it take into account any other incomes which may be generated by interest and dividends from investments.

Housing affordability is increasingly becoming an important issue facing local communities. Lakeville should look toward zoning alternatives, including density bonuses for clusters and accessory apartments, for ways to ease the housing crunch. 
TABLE 18

IMCOME FROM DIRECT EMFLOYMENT

AND THE MUMBER OF JOBS PER INCOME RAMGE

\begin{tabular}{lrrrrr} 
YEAR & 14,999 & 15,000 & 20,000 & 25,000 & \\
19,999 & 24,999 & + & TUTAL \\
\hline 1990 & 16 & 1,156 & 243 & 36 & 1,442 \\
1995 & 104 & 2,720 & 715 & 156 & 3,695 \\
2000 & 144 & 3,846 & 972 & 238 & 5,199 \\
2005 & 144 & 4,226 & 972 & 238 & 5,579
\end{tabular}

Sources: The four development EIR'5. Massachusetts Division of Eaplaysent Securities. 
COMMUNITY FACILITIES

This section estimates the impacts on community facilities based on the direct impacts of the four developments and the probable need for services due to the increase in population. To accomplish this, however, an analysis of existing conditions had to be drawn first.

The methodology used in this section relied on the use of national standards as a means of comparison. However, when more relevant data was avallable, reglonal standards were substituted.

1. Existing Condition of Lakeville Fac1lities

a. Police Protection

The Town of Lakeville presently employs 16 police officers and owns five crulsers plus two unmarked vehicles. The police station is centrally located on Bedford street and contains a square footage of 3,200 . (see Map 15 for location of all public facilities)

When compared to the national standards (see Table 19), the Town of Lakeville exceeded the staffing standard of 1.5 police officers per 1,000 population by 0.86 , or about 6 patrolmen. The number of police vehicles exceeded the 
COMMUNITY FACILITIES

1. Town Hall and Fire Station

2. Police Station

3. Assawompset Elememtery School

4. Austin Middle School and Apponequet Regional High School

5. Clear Pond Park

6. Ted Williams Park

7. Lakeville Hospital

B. Taunton Water Division Pumping Station
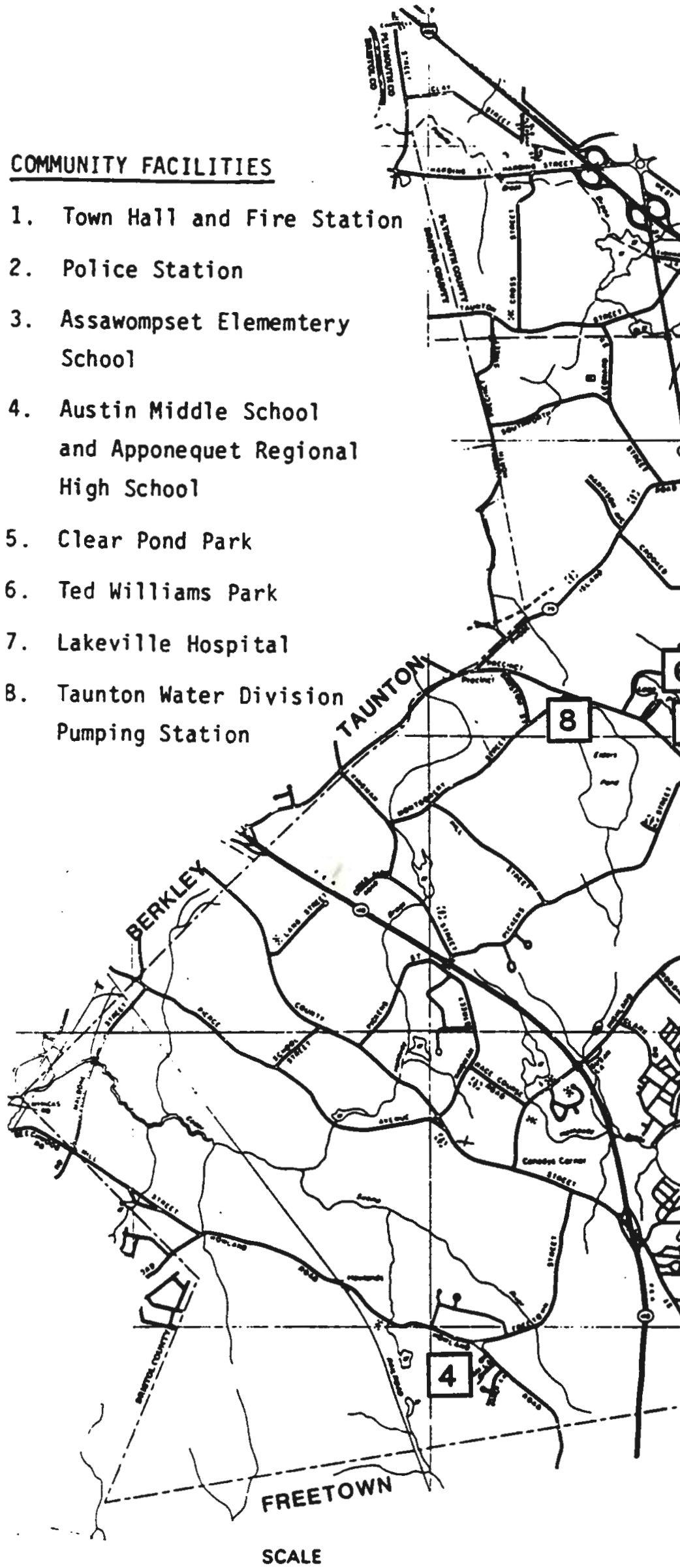
standards by 0.43 or around 3 cars. And finally, the square feet of facility space fell short of the standards by 25 square feet per officer.

These standards may however, be too low for the large geographic size ( 36 square miles) of the community in terms of personnel and vehicles.

The police chief has submitted to Lakeville Board of Selectmen a proposal for a study committee for a new facility to relieve the over crowding in the present police building. Chief Bowles indicated a need for more space for files, office space, locker space for the officers, and a cell for women prisoners among other facilities. The purpose of this proposed study will be to indicate the exact space needs and probable costs.

\section{b. Fire Protection}

Lakevilie's Fire Department has seven full time and 23 oncall firefighters, as well as mutual aid agreements with surrounding towns. It owns seren trucks and one car and is housed in a 6,134 square foot facility. The fire station is located on Bedford street in the center of town. 
Compared to National Standards, Lakeville's Fire Department looks poorly equipped (see Table 19). The Town of Lakeville exceeded the staffing standard of 2 full time firemen per 1,000 dwelling units by 1.03 , or about 2 firefighters. The number of firefighting vehicles is difficult to relate to the present conditions. It exceeded the standards of 4 vehicles per station by 4 vehicles; however, it fell short of the total number of vehicles by 1 , when the number of fire stations per 1,000 dwelling units were flgured in.

The square feet of facility space fell short of the standards by 2,465 square feet. The reason for this is because the standards require 1 station being 5,120 square feet per 1,000 dwelling units. In the case of Lakeville, the one fire station is 6,134 square feet; however, another station $1 \mathrm{~s}$ required.

The difficulty with national standards is that they are very general and do not take into account the size of a town, the population density throughout the town, and other mitigating factors like mutual aid.

\begin{abstract}
A spokesman for the Lakeville Fire Department stated that the department needs substations in both the north and south ends of town, but most critically in the south end. Ho funding is Immediately avallable for these facilities.
\end{abstract}


TABLE 19

EXISTING FACILITIES

Lakeville population 1985: 6785

dwelling units : 2310

\begin{tabular}{|c|c|c|c|c|}
\hline & $\begin{array}{l}\text { LAKEVILLE } \\
\text { (Total) }\end{array}$ & $\begin{array}{l}\text { LAKEVILLE } \\
\text { (y) }\end{array}$ & NATIONAL STANDARDS & LAKEVILLE \\
\hline officers & 16 & 2.36 & $1.5 / 1000$ population & $0.86 / 1000$ population \\
\hline vehicles & 7 & 1.03 & $0.6 / 1000$ population & $0.43 / 1000$ population \\
\hline facility (S.F.) & 3200 & 200 & 225 /police officer & -25 /pulice officer \\
\hline \multicolumn{5}{|l|}{ Fire: } \\
\hline firemen full tiae & 7 & 3.03 & 2 /1000 dwelling units & $1.03 / 1000$ dwelling units \\
\hline vehicles & 8 & 8 & 4 /fire station & 4 /fire station \\
\hline facility $\left(S_{.} F_{.}\right)$ & 6134 & $2655 / 1000 \mathrm{D}$ & $5120 / 1000$ dwelling units & $-2465 / 1000$ dwelling units \\
\hline
\end{tabular}

Source: "Iopact of Grouth", Lewis Publishing Co. Inc., 1984, Tables 9, 11.

c. Public Water and Sewer

Lakeville, like many other small communities, has limited public facilities. The Town has no public water system or public sewer system of its own. There 1s, however, access to both the Taunton systems and the Middleborough systems for the four developments under study. These will be analyzed in the "Direct Impacts of the Four Developments" portion of this section. 
2. Projected Direct Impacts of the Four Developments

The services provided by Lakeville which are relevant to the examination of the impacts of the four developments are police protection, fire protection, and water and sewer services.

In general, industrial development which is able to use on-site sewage disposal, has limited water service requirements and is relatively self-sufficient in terms of security need not trigger major public investment (except, perhaps, in the area of roadway improvements) or increase in ongoing service costs. These costs are calculated in the "Analysis of Municipal Costs and Revenues" section of this chapter.

\section{a. Police Protection}

The impacts of the growth upon police protection within the four developments will be mitigated by the following factors. F1rst, Ocean Spray will employ 1ts own security force. Secondly, Lakeport Park, while not having 1ts own security force, w1ll have burglar and fire alarms tied into a master alarm station at the entrance to the park. Furthermore, Lakeport is near the businesses along Route 44 , which is already patrolled by Lakeville Polloe Cruisers. Thirdly, at least two of the businesses in Great Ponds Park will employ 
their own security forces; they are the Talbots and Rix-

Dunnigton warehouses. And finally, while the impact of the Riverside Industrial Park is harder to estimate due to the preliminary stages of development, it may be assumed that the MBTA station will maintain a security staff on the site.

It should be noted, however, that even the presence of private security forces will not relieve the town of 1 ts obligation to provide police protection to these developments.

\section{b. F1re Protection}

Both the towns of Lakeville and Middleborough provide fire protection to the northern end of Lakeville, where the four development sites are located. The response time of the two fire departments to these sites as follows:

$\begin{array}{lll}\text { Site } & \text { Lakevilie F.D. } & \text { Middleborough } \\ \text { Lakeport } & 7-8 \text { minutes } & 5 \text { minutes } \\ \text { Ocean Spray } & 5 \text { minutes } & 6-7 \text { minutes } \\ \text { Great Ponds } & 5 \text { minutes } & \\ \text { Riverside } & 5 \text { minutes }\end{array}$

It appears that there will be a long term need for a new fire station in the northern area of Lakeville. 
However, the Town of Middleborough has recently voted funds to develop plans and specifications for a new fire station to be constructed at Bedford street and Clay street, within onequarter mile from the Ocean Spray headquarters. The new fire station is expected to be fully operational within three years. The town of Lakeville should coordinate the siting of any new fire station in its northern end to complement the coverage of Middleborough's new facility.

\section{c. Water Services}

Three of the developments will be served by the Taunton water system, Lakeport Park, Ocean Spray and Great Ponds, while the plans for Riverside are still indefinite. The Taunton system is more than adequate to meet the water consumption of the four sites. Taunton's water system draws on four ponds located in Lakeville and presently pumps 8 million gallons per day. The city is expanding its system to serve Massachusetts Correctional Institution (MCI) Bridgewater and the adjacent residential area. It hopes to further expand its services to other towns in the region. The safe gield of the Taunton system is 21.3 million gallons per day over an extended period of time. 


\section{d. Sewage Generation}

Two of the four developments are using on-site disposal for their sewage; they are Lakeport Park and Great Ponds. The Ocean Spray headquarters will be served by the Middleborough sewer system. Rough calculations of the sewage generation by the Ocean Spray facility (based on DEQE Title 5 standards of 75 gallons/1,000 sq. ft./day for office buildings) indicates a sewage flow of 11,250 gallons per day (gpd) by 1990 and 22,500 gpd after 1995 .

Plans for the Riverside site are not final in this area. However, reliance on the Middleborough system is not an option since all of the excess capacity of their treatment plant is reserved for projected future growth within the community. This includes both the Ocean Spray headquarters, and the Middleborough Development Opportunities District. It is likely that Riverside Park will have to rely on an on-site septic system, unless an arrangement is reached with the state to upgrade Middleborough sewerage treatment capacity.

\section{Profected Impacts of Induced Population Growth}

The estimated Induced growth in Lakeville's population and housing units were presented in Tables 11 and 12 . These Tables showed that the maximum induced growth occurs in the year 2000. Since the projected impact is less than 8 percent 
of the total projected baseline population and housing units over the entire study period, it is expected that the impact on all community services will be small. Lakeville is already attempting to cope with pressures of an approximately 14 percent growth rate between 1980 and 1985 , when the population grew from 5,931 to an estimated 6,785. This growth is presently impacting recreational and educational services.

\section{a. Police and Fire Protection}

The following Tables show the projections for increased police and fire protection needs of the community based on the baseline trend population and the induced growth population.

TABLE 20

PRCJECTED FOLICE AND FIRE PROTECTION NEEDS

(Based on National Average)

\begin{tabular}{|c|c|c|c|c|c|c|c|c|}
\hline & \multicolumn{4}{|c|}{ Police } & \multicolumn{4}{|c|}{ Fire } \\
\hline & 1990 & 1995 & 2000 & 2005 & 1990 & 1995 & 2000 & 2005 \\
\hline & --- & --- & --- & $-\cdots$ & $\cdots$ & --- & ---- & -- \\
\hline \multicolumn{9}{|c|}{ Baseline fupulation: } \\
\hline Personnel & . 13 & 15 & 18 & 21 & 6 & 7 & 9 & 10 \\
\hline Vehicles & 5 & 6 & 7 & 8 & 12 & 14 & 17 & 21 \\
\hline Facility* & 2,845 & 3,398 & 4,014 & 4,720 & 15,186 & 18,458 & 22,323 & 26,726 \\
\hline \multicolumn{9}{|c|}{ Baseline + Induced Grouth Pupulation: } \\
\hline Personnel & 13 & 16 & 19 & 22 & 6 & 8 & 9 & \\
\hline Vehicles & 5 & 6 & 8 & 9 & 12 & 15 & 19 & \\
\hline Facility & 2,933 & 3,609 & 4,317 & 5,041 & 15,657 & 19,661 & 24,013 & 28,539 \\
\hline \multicolumn{9}{|l|}{ Difference: } \\
\hline Persannel & 0 & 1 & 1 & 1 & 0 & 0 & 1 & \\
\hline Vehicles & 0 & 0 & 1 & 1 & 0 & 1 & 1 & \\
\hline Facility* & 88 & 22! & 304 & 321 & 471 & 1,203 & 1,690 & 1,812 \\
\hline
\end{tabular}

- Facility nubber represents square feet.

Source: "Inpact of Growth", Lewis Publishing Co. Inc., 1984. 


\section{b. Hater Use and Sewage Generation}

There is no public water supply to residential areas in Lakeville, except to a few homes in western Lakeville on the Taunton water system and to Lakeville Hospital and several homes along the line on the Middleborough water system. Furthermore, there is no public sewerage system in the town. Therefore, considerations of projected water use and sewage generation is not pertinent.

\section{c. Solid Waste Generation}

Presently, Lakeville is served by a municipal landfill and commercial haulers, although most residents take their own trash to the landfill. It is estimated that the total residential, commercial and industrial waste from Lakeville is presently 4,000 to 5,000 tons per year.

According to SEMASS, a regional solid waste management facility, residential solid waste generation is approximately 2 to 2.5 pounds per person per day in a rural area without recycling. Based on this standard, the 1985 residential population of Lakevilie, estimated to be 6,785 , would generate approximately 6.8 to 8.5 tons per day or 2,500 to 3,100 tons per year. 
The town has contracted with SEMASS to handle a minimum of 3,200 and a maximum of 3,520 tons of residential solid waste per year. The impact of the induced residential growth on solid waste generation was calculated using the standard of 2.5 pounds per person per day obtained from semass. The results are as follows:

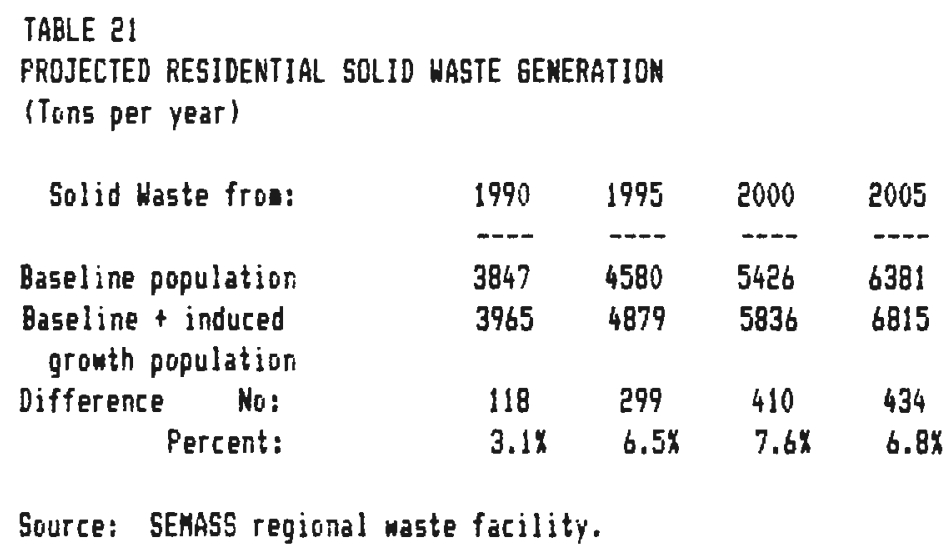

This study's projection of the town's residential solid waste exceeds the maximum contracted tonnage some time before 1991 (ror both the baseline population and induced growth population). Although there is some flexibility in the contract and the maximum tonnage can be increased, this cannot be done before May 1993 and can only be Increased by 2 percent. 


\section{d. Educational Facilities}

An educational needs study was undertaken for the FreetownLakeville School District by Dr. John A. Calabro \& Associates of Cohasset. The draft of the study was completed in June of last year and is now under review by the town and school district.

At the time of this study, a major addition and renovation program was being undertaken at the Assawompsett Elementary School in Lakeville. The Calabro study states that "the enlargement will alleviate overcrowding and provide needed spaces for program now operating in corridors and closets." However, "it is probable that Assawompsett will be at capacity by 1989 and, if projections prove correct, it is certain that new facilities will be needed by the following year somewhere... Based upon State Department of Education standards, as well as general current good practices, the Assawompsett Elementary School has reached its ultimate size and should not be further enlarged to accommodate expanding numbers." A new elenentary school 18 reoomended for another location somewhere in Lakeville. It is also recommended that the elementary system be expanded to grade 5 to relieve the likely future crowding in the middle school. It presently serves just grades $\mathrm{K}-4$. 
The Austin Middle School serves grades 5 through 8 and has a rated capacity of approximately 998 pupils. The enrollment in the spring of 1988 was 952 . The assessment of the middle school was that the building was adequate to meet the needs of the student population with some redesign of space allocation and major improvements in the heating and air conditioning systems.

The Apponequate Regional High School is presently undergoing an ambitious renovation and expansion program which should provide adequate space and number of classrooms for the near future.

Comparisons between Calabro's school enrollment projections and SRPEDD's are difficult because the Calabro study assumes a higher birth rate and rate of in-migration than SRPEDD does. As a result, it projects a higher grades $K-4$ population. However, using SRPEDD's methodology, the impacts of the households moving into Lakeville as a result of the four developments can be analyzed. The results are displayed In Tables 22 and 23 .

The per pupil costs were the latest avallable from Freetown Lakevilie Superintendent of Sohool's office. They represent total school budget expenditures. Information on the town portion of these costa was not readily avallable (Table 24 ). 
TABLE 22

PROJECTED SCHOOL AGE CHILDREN IN LAKEYILLE

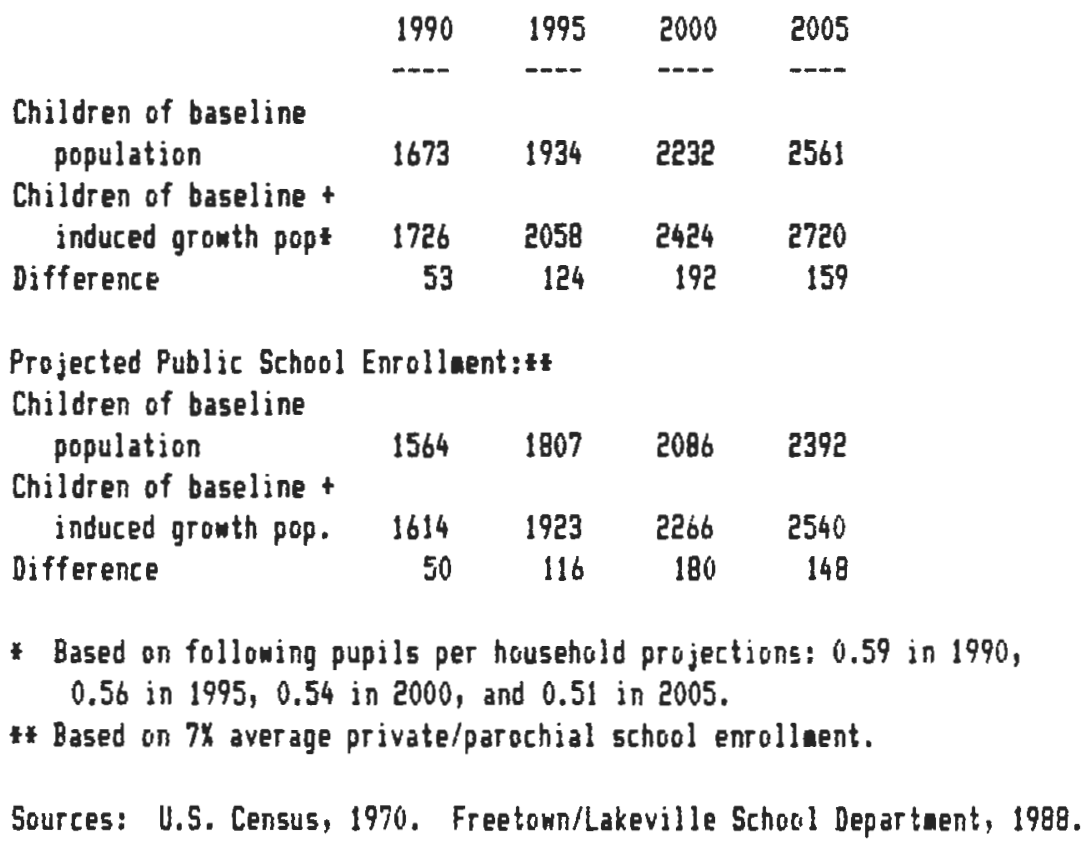


TABLE 23

ESTIKATED GRADE BREAKDOWN OF NET PROJECT

IMDUCED GROHTH ENROLLED IN LAKEVILLE SCHOOLS

\begin{tabular}{lrrrr} 
Grade & 1990 & 1995 & 2000 & 2005 \\
\hdashline--- & --- & $-\cdots$ & --- \\
Kindergarten & 4 & 8 & 13 & 11 \\
Grades 1-4 & 14 & 33 & 51 & 42 \\
Grades 5-12 & 32 & 74 & 116 & 95 \\
Total & 50 & 116 & 180 & 149
\end{tabular}

Sources: Calabro Study, Dr. John A. Calabro Associates, 1998. Freetown/Lakeville School Departaent, 1988.

TABLE 24

PROJECTED SCHOOL EXPENDITURES

\begin{tabular}{|c|c|c|c|c|c|}
\hline frade & Fer Pupil & & & & 2005 \\
\hline oraode & $605+180$ & 1970 & 1945 & ENow & 2005 \\
\hline Kindergarten & $\$ 1,207$ & $\$ 4,828$ & $\$ 9,656$ & $\$ 15,691$ & $\$ 13,277$ \\
\hline ades $1-4$ & $\$ 1,956$ & $\$ 27,384$ & $\$ 64,548$ & $\$ 99,756$ & $\$ 82,152$ \\
\hline Grades $5-12$ & $\$ 2,528$ & $\$ 80,896$ & $\$ 187,072$ & $\$ 293,248$ & $\$ 240,160$ \\
\hline tal & & $\$ 113,108$ & $\$ 261.276$ & 408,695 & $\$ 335,5$ \\
\hline
\end{tabular}

Source: Freetown/Lakeville School Department, 1988. 


\section{e. Recreation Facilities}

The standards obtained from the "Impact of Growth" book of 3.9 acres of playgrounds and 3.3 acres of neighborhood parks per 1,000 dwelling units, indicated that Lakeville was well above the national average. However, a 1981 SRPEDD prepared Lakeville Open Space Plan, found that the recreational facilities were generally adequate for the town residents, although there was a deflciency in the neighborhood parks (by about 11 acres), playgrounds ( 24 acres), hiking areas ( 6 acres), nature study areas and campsites as compared with the National Bureau of Outdoor Recreation Space Standards. It was recommended at that time that the town develop access to beach frontage along Long Pond, develop nature trails within some existing conservation areas and continue to maintain existing recreational facilities. A greater emphasis was placed on protecting water supplies and watershed areas, as well as preserving farmlands.

Since that time, Lakeville has lost access to two ballfields with the construction of a new addition to one of the schools. This development overloaded the existing ballfields, one of which has severe drainage problems (at John Paun Memorial Playground). 
As a result, the town acquired the 148 acre, Ted W11liams Boys' Camp/Lakeville Tennis Club. The ballfields, tennis courts and basketball court have been $10 n g$ neglected and need much work to bring them up to satisfactory conditions. The town recently approved $\$ 22,000$ to do work on the ballfields; to construct new backstops and to provide restroom facilities. Many other improvements remain to be done at both the Paun Playground and at the old Ted Williams Camp. In addition, the Park Commission hopes to add a bocce court and walking and jogging paths to the old camp.

Thus, the town is doing its best to catch up with the growing recreational needs of its residents. Plaggrounds, ballfields and other facilities are being upgraded slowly with limited funds. The numeric difference between the projected baseline population and the induced growth population is not so great as to require any more recreational facilities by the year 2005 
The Transportation Impact section of this report was produced by Thomas A. Pisaturo, the Comprehensive Planning Manager of Southeastern Regional Planning and Economic Development District. Due to the importance of this section, it will remain in the Thesis Project for the benefit of those who may wish to use this analysis, as a guide.

The following is an analysis of traffic impacts based on the existing highway network and the employment characteristics of each of the four developments as described in Tables 5 through 8. The analysis focuses on the morning and evening peak hour periods and on major intersections. Peak hour periods are the portion of the day with the heaviest traffic. Intersections are the critical control points at which traffic congestion and/or accidents are most likely to occur because of the conflicting vehicular flows that occur at these points. Theoretically, if intersections are functioning adequately, the highway segments should also be functioning adequately.

\section{Methodology}

The methodology used in this analysis was to estimate the number and direction of peak hour trips to and from the four developments (based on their employment characteristics) and 
distribute these trips to the highway system. The MBTA Train Station at Riverside Park was treated as a separate entity, due to 1ts unique characteristics. These calculations were made for the years 1990, 1995, 2000 and 2005. Existing traffic counts were derived from a number of recent survegs conducted by the State DPW and SRPEDD in 1986 and 1987. Th1s is added to the highway system and $1 \mathrm{~s}$ assumed to grow by $1.5 \%$ per year to reflect the growth in background traffic. Background traffic grows because of other developments in the study area such as the secondary employment and population growth.

Two additional developments are examined directly by this study: the Raynham Woods Corporate Park and the Middleborough Development Opportunities District. These are very large developments which will generate a significant amount of traffic and will have a significant impact on the roadways in the area.

\section{Study Area}

The study area includes the intersections lmmediately surrounding the four developments. These intersections are:

1. Route 79 (Rhode Island Rd.)/Route 18 (Bedford St.)

2. Route 79 (Rhode Island Rd.)/Clear Pond Road 
3. Route 79 (Rhode Island Rd.)/Route 105 (Main St.)

4. Route 105 (Main St.)/Route 18 (Bedford St.)

5. Route 18 (Bedford St.)/Highland Road

6. Middleborough Circle

7. Route $44 /$ Route 495 Northbound ramp

8. Route $44 /$ Route 495 Southbound ramp

9. Route 18 (Bedford St.)/Route 495 Southbound ramp

10. Route 18 (Bedford St.)/Route 495 Northbound ramp

11. Route 105 (Main St.)/Route 495 Southbound ramp

12. Route 105 (Main St.)/Route 495 Northbound ramp

These intersections will be direotly affected by traffic from the four developments. They are also important traffic control points which control the access of Lakerille's residents to the area's highway system. 


\section{Trip Generation}

Vehicular trips were generated for seven developments Raynham Woods, Lakeport Park, Ocean Spray Corporate Headquarters, the Middleborough Development Opportunities District, Great Ponds Industrial Park, Riverside Park, and the MBTA Train Station. In general, trips were generated by applying the estimates of employment (Tables 5 through 8) for each time period to peak hour trip rates taken from the Trip Generation Manual of the Institute of Transportation Engineers. In the case of Raynham Woods trips were taken from the Environmental Impact Report for the development. Trips for the MBTA Train Station were taken from data developed by the MBTA. Table 25 summarizes the trips for each development.

The trips for ocean spray are lower than other uses of 1 ts size because of the characteristics of the use. Large office buildings tend to have their trips spread out more evenly over the course of the day to reflect the comings and goings of corporate officers and marketing personnel.

\section{Trip Distribution}

In general, the trip distributions of the project developers (as shown in the EIR's and other studies) were accepted. However, distributions had to be developed for Lakeport and 


\begin{tabular}{|c|c|c|c|c|c|c|c|c|c|c|c|c|c|c|c|c|}
\hline & \multicolumn{4}{|c|}{1990} & \multicolumn{4}{|c|}{1995} & \multicolumn{4}{|c|}{2000} & \multicolumn{4}{|c|}{2005} \\
\hline & A. & & & & & & & & & & & & & & & PEAK \\
\hline & III & & IN & out & In & out & In & OUT & If & OUT & IfI & out & In & OUT & & \\
\hline RAYMNM LOODS & 394 & 69 & 107 & 462 & 1600 & 193 & 291 & 1346 & 2767 & 313 & 463 & 2246 & 2767 & 313 & 463 & 2246 \\
\hline LAKEPORT & 60 & 15 & 40 & 150 & 160 & 40 & 90 & 380 & 320 & 80 & 200 & 770 & 320 & 80 & 200 & 770 \\
\hline OCEM SPRAY & 130 & 23 & 14 & 97 & 220 & 45 & 25 & 165 & 335 & 65 & 35 & 250 & 335 & 65 & 35 & 250 \\
\hline MTDOLEDROUEH DOD & 904 & 205 & 312 & 803 & 1807 & 410 & 623 & 1606 & 2710 & 614 & 933 & 2408 & 3613 & 819 & 1245 & 3211 \\
\hline GEAT PONDS & 325 & 65 & 163 & 505 & 700 & 140 & 350 & 1260 & 1100 & 220 & 550 & 1980 & 1300 & 260 & 650 & 2340 \\
\hline RIVERSIOE & 135 & 27 & 68 & 243 & 640 & 128 & 320 & 1152 & 640 & 128 & 320 & 1152 & 640 & 128 & 320 & 1152 \\
\hline WITA TRAIU STATION & - & -- & -- & - & 324 & 58 & 58 & 324 & 324 & 58 & 58 & 324 & 324 & 58 & 58 & 324 \\
\hline
\end{tabular}

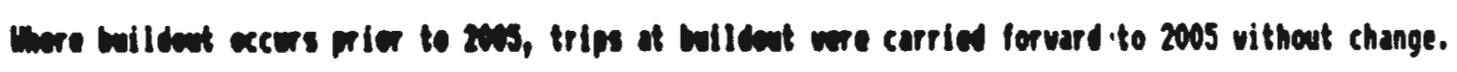

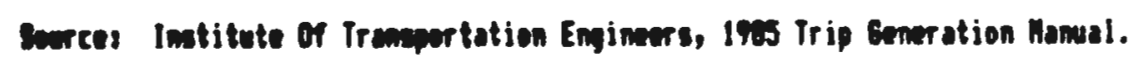


Riverside. The trip distribution for Great Ponds had to be modifled from the developer's estimated 408 of the traffic to originate from Route 18 south to 20\%. This distribution was modified to a more even distribution reflective of a large development drawing employees from the Brocton and Taunton areas. The trip distribution pattern for each project 13 shown on maps 16 through 22. In some cases the total percent of trips shown on a road is the total of trips from two or more down stream roads. For example, Map 22 shows 108 of trips or 1ginating from Route 18 south of Route 495 . However, this is composed of trips originating from Route 79 (2.58), H1ghland Road ( 5.08 ) and Route 18 south of Highland Road (2.58). 


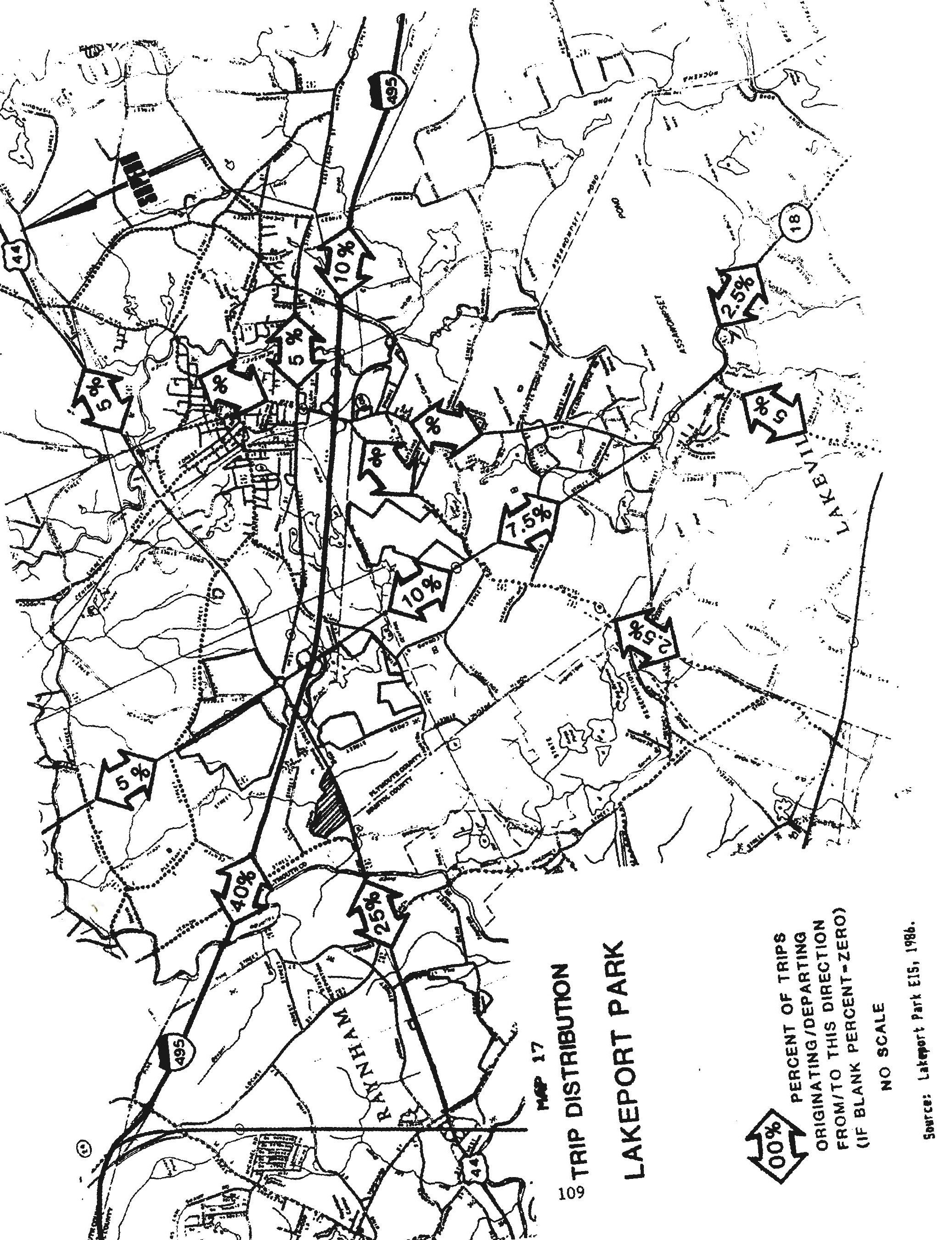





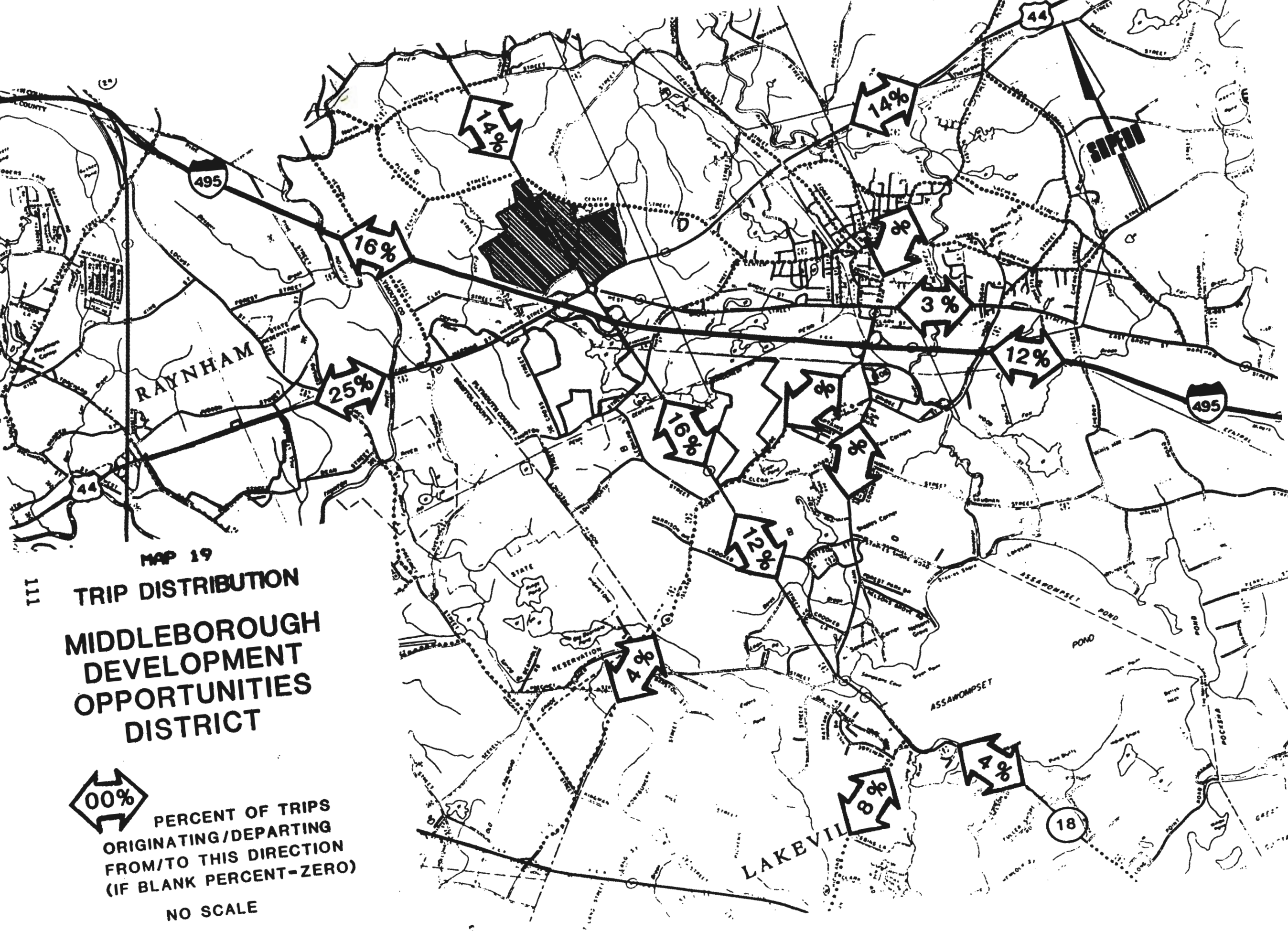

$$
\text { NO SCALE }
$$




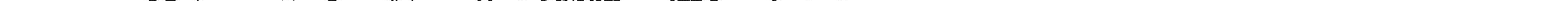



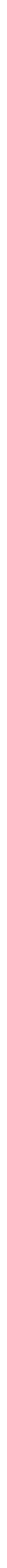


\section{Volume/Capac1ty Analys1s}

Intersection capacity was analyzed using the Highway Capacity Manual computer program of the Federal Highway

Administration. The program utilizes the level of service concept. The level of service concept can be used to evaluate the performance of highway intersections and the impact that additional traffic volume will have on the operating characteristics of those intersections. Six levels of service have been established to describe different operating conditions. Level of service (LOS) A describes a condition of free flow with little or no delay. LOS B and C have stable traffic flow short to average delays. LOS D through $F$ describe conditions where traffic flows become unstable with long to very long traffic delays. The upper limit of level of service E is considered the capacity of the roadway below which driving comfort is low and accident potential is high.

The results of this analysis show significant capacity problems at nearly every intersection in the study area early into the study period. Many intersections are projected to experience problems by 1990. These problems will become more severe as time passes and traffic flow increases. The results of the analysis for each intersection are described briefly below. 
Route 79 (Rhode Island Rd.)/Route 18 (Bedford St.) - It is projected that in 1990 the westbound approaches of Route 79 will operate at Level of Service F during PM peak hour. By 1995, both approaches of Route 79 are projected to operate at LOS F during the PM peak hour. (Improvements to this Intersection were proposed as part of the Great Ponds Environmental Impact Report.)

Route 79 (Rhode Island Rd.)/Clear Pond Road - The worst projected LOS is E for Left turns from Clear Pond Road onto Route 79 during PM peak in 2000 and 2005 .

Route 79 (Rhode Island Rd.)/Route 105 (Main St.) - In 1990 left turn movements from Route 105 onto Route 79 are projected to operate at LOS E during the AM peak hour and LOS F during the PM peak hour. By the year 2000 it is projected that right turn movements from Route 79 onto Route 105 will operate at LOS E during the AM peak hour. (Improvements to this intersection were proposed as part of the Great Ponds Environmental Impact Report.)

Route 105 (Main St.)/Route 18 (Bedford Rd.) - During the AM peak hour in 1990 both the left turn and through movements from Route 105 westbound onto Route 18 are projected to operate at LOS F. The eastbound left turn and through movements form Route 105 are projected to operate at LOS E, during the 1990 AM peak hour, deteriorating to LOS F by 1995 . 
Route 18 (Bedford Rd.)/Highland Rd. - The left turn movement from Highland Road onto Route 18 will operate at LOS F during both the AM and PM peak hours in 1990. By 1995 the left from Route 18 onto Highland Road operates at LOS E during the PM peak hour.

Middeborough Circle - It is difficult to calculate level of service for rotaries because of their unique characteristics. However, they are considered to operate satisfactorily when all approach legs carry no more than 3,000 vehicles per hour. The projected vehicles per hour for the Middleborough Circle range from 3,506 in 1990 during the AM peak hour to 8,350 in 2005 during the PM peak hour.

Route $44 /$ Route 495 Northbound ramp - Projected conditions in 1990 are LOS E in the AM peak hour for left turns onto Route 44. In 1995 left and right turns from the ramp in the $A M$ peak will be at LOS $E$ and $F$ respectively. All critical turning movements are projected to operate at LOS F during the PM peak hour by the year 2000 .

Route 44/Route 495 Southbound ramp - This intersection is projected to experience LOS $F$ in the AM peak hour for left turn movements from the Route 495 ramp onto Route 44 and LOS F for both left and right movements from the Route 495 ramp onto Route 44 in the PM peak hour. Conditions are projected to deteriorate as traffic volumes grow in the future. 
Route 18 (Bedford St.)/Route 495 Southbound ramp - Projected conditions are LOS E during the 1990 PM peak hour for left turns from the Route 495 ramp onto Route 18 . By the year 2000 the PM peak hour left turn movement from the ramp onto Route 18 is st111 at LOS E, but the right turn movement onto Route 18 has deteriorated to LOS F.

Route 18 (Bedford St.)/Route 495 Northbound ramp - In 1990 the left turn from the Route 495 ramp onto Route 18 is projected to operate at LOS E in the AM peak hour. By the year 2000 both the left and r1ght turn onto Route 18 are projected to operate at LOS F during the AM peak hour.

Route 105 (Main St.)/Route 495 Southbound ramp - Projected conditions are LOS F in 1990 for left turns from the ramp onto Route 105 during the PM peak hour. By 1995 left turns from Route 105 onto the ramp are also projected to operate at LOS F.

Route 105 (Main St.)/Route 495 Northbound ramp - In 1990 left turns from the Route 495 ramp onto Route 105 w11 experience LOS F during the AM peak hour. Left turns from Route 105 onto Route 495 w11 operate at LOS E during the PM peak hour by 1995. 


\section{Summary}

Nearly every major intersection in the study area is projected to experience operating problems during the study period. In many cases these problems may develop by 1990. In some instances the problems can be corrected by Intersection improvements such as widening, channelization and signalization. Improvements of this nature have recently been proposed for Route $79 /$ Route 18 1ntersection and Route 79/ Route 105 intersection. However, some 1ntersections, such as the Middleborough Circle, are projected to recelve so much traffic that only major road reconstruction will alleviate the problem. Delays at a number of intersections w11l be so severe that drivers w11l have no cho1ce but to seek alternative routes. Th1s will cause congestion on other local streets not covered by this study. 


\section{CHAPTER IV}

\section{RECOMMENDATIONS AND ZONING REVISIONS}




\section{INTRODUCTION}

Having examined the physical characteristics of the four developments and their impacts on the town, the final chapter lays out, first, the specific recommendations for the previous analysis and, secondly, looks at the existing growth policies of Lakeville and their ability to deal with these projected 1 mpacts.

\section{RECOMMENDATIONS}

\section{Land Use and Housing Affordability}

The Land Use analysis looked at the land area required to house the primary and secondary employees created by the four developments. Table 13 displayed three different zoning scenar1o's ranging from the present town zoning to zoning of the surrounding towns.

The comparison indicated that a change in zoning from one unit per 70,000 square feet to a mixture of allowed lot sizes w1ll reduce the amount of land area needed to house the Increasing population (see Table 13). This finding is further strengthened by the Bousing arfordability analysis. 
The Housing Affordability analysis indicated that the average wage pald for the direct and indirect employment created by the four developments would not be enough to cover local housing costs. The result would be a need for a greater number of affordable housing units for the employees. Therefore, it is recommended that the current zoning requirements be altered to allow cluster development.

The clustering of housing units would lower the costs of housing by reducing the cost of site improvements. By reducing the land requirements for roads, more open space can be produced for the common use of residence. Furthermore, accessory apartments, another recommendation from the Housing Affordability analysis, would increase the supply of rental housing and thereby lowering the demand for new housing construction on available land.

\section{Community Fac1l1ties}

The Community Facilities analysis indicated that generally the town's facilities are in good shape. The exceptions were related to bullding space for the Police and Fire departments.

The Lakerille Police Headquarters, according to the Chief, is lacking in office space as well as a women's prison cell. We back the Police Chief's proposal for a facilities study 
and further recommend that the police station remain in its present central location.

The Lakeville Fire Department was also determined to be insufficient for total coverage of the town. However, unlike the police station which can be expanded to increase its space, a second fire station is needed for a proper response time for other sections of the town. It is recommended that a study committee be formed and that the committee meet with the Middleborough Selectmen to assess the proper location for the future station.

Finally, the Community Facilities analysis of this report revealed the need for further study relating to the residential solid waste. We project the town's residential sol1d waste w1ll exceed the maximum SEMASS contracted tonnage by the year 1991. This could be a serious problem and demands attention.

\section{$\underline{\operatorname{Traff} 1 \mathrm{c}}$}

This section studied the traffic impacts on the town resultant from the four developments. This analysis indioated that Lakerille is going to experience severe congestion in the coming years. There are two recommendations that are strongly made in regards to the future traffic flow. 
First, it is recommended that a major traffic circulation study of the area be undertaken to explore options for alleviating the impacts described by this analysis. The project should be a traffic engineering study in which alternative design concepts from intersection improvements to new road construction are developed and evaluated.

Secondly, this study has shown that the intersections in the vicinity of the four developments cannot handle the traffic from the non-residential developments presently approved. In the absence of major highway improvements, it is recommended that Lakevilie review its zoning and consider down zoning to restrict the construction of any large non-residential projects. Lakeville should urge its neighboring towns to do the same with their zoning. 
The Lakeville growth policies that were analyzed are: 1) the Protective Zoning By-Laws, 2) the Subdivision Regulations, 3) the Board of Health Regulations, 4) the Conservation Commission Regulations, and 5) other town ordinances and bylaws deemed appropriate. Opon review, several recommendations are suggested with reference to the first three. There are also several recommendations regarding the requirements of the Zoning Board of Appeals.

Sample warrant articles and regulations are lncluded in the append1x.

PROTECTIVE BY-LAH

An extensive review of Lakeville's current zoning by-law (known as the Protective By-Law) was conducted and the recommendations are as follows:

\section{Recodification}

At present, Lakeville's zoning by-law is difficult to read and interpret; therefore, it has been recommended that a complete recodification of the by-laws be done. This recodification would eliminate some loop holes and technical deficiencies and produce a more readable document. It would 
also be easier to amend in the future and provide better protection for the town's natural environment and rural character.

It is suggested that the recodification be organized in the following format:

Section One: Administration and Procedure

1.01 Purpose

1.02 Enforcement

1.03 Permits

etc.

Section Two: Definitions

Section Three: Establishment of D1stricts

Section Four: Use Regulations

Section Five: Dimensional and Density Regulations

Section Six: General Regulations

6.01 Off Street Parking Requirement

Section Seven: Special Permit Regulations

7.01 Site Plan Review

7.02 Aquifer Overlay D1stricts 


$$
\begin{array}{ll}
7.03 & \text { Cluster } \\
7.03 .3 & \text { Inclusionary } \\
7.04 & \text { Accessory Apartments }
\end{array}
$$

In addition, the zoning map should be updated and reproduced at acale that can be sold with the zoning bylaw.

\section{Definitions}

The second recommendation for the Protective By-Law is for definitions to be added to the text. These additional definitions will assist the enforcement agent and local boards in the determination of uses.

The following words should have definitions supplied in the by-law:

$\begin{array}{ll}\text { Aquifer } & \text { Area, Floor } \\ \text { Abandonment } & \text { Basement } \\ \text { Accessory Building } & \text { Boathouse Private } \\ \text { Accessory Ose } & \text { Boathouse Public } \\ \text { Alterations } & \text { Boarding Bouse } \\ \text { Airport } & \text { Buffer Setback } \\ \text { Animal Feedlot } & \text { Building } \\ \text { Animal Kennel or Hospital } & \text { Building, Coverage } \\ \text { Area, Building } & \text { Building, Attached }\end{array}$




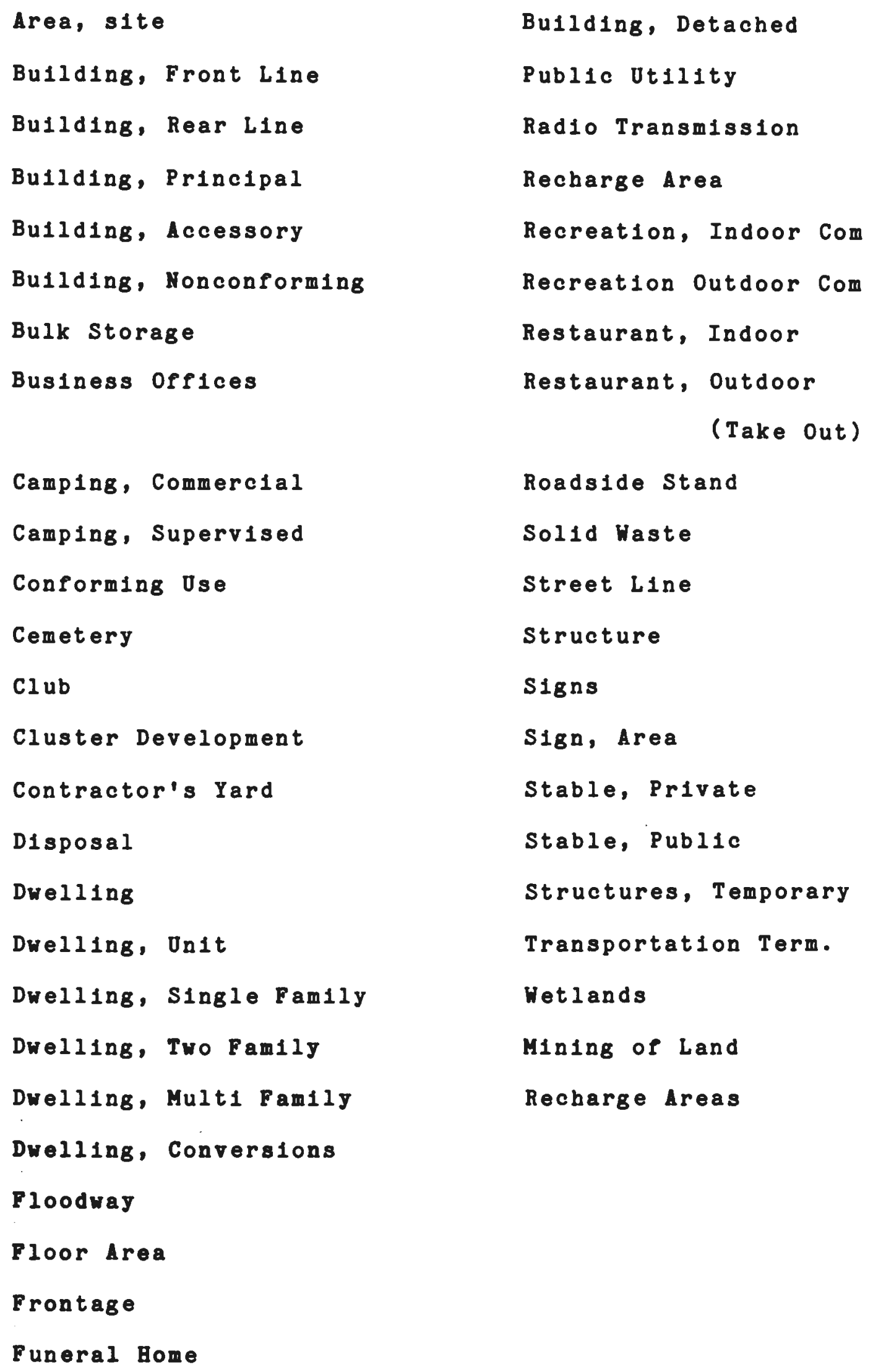




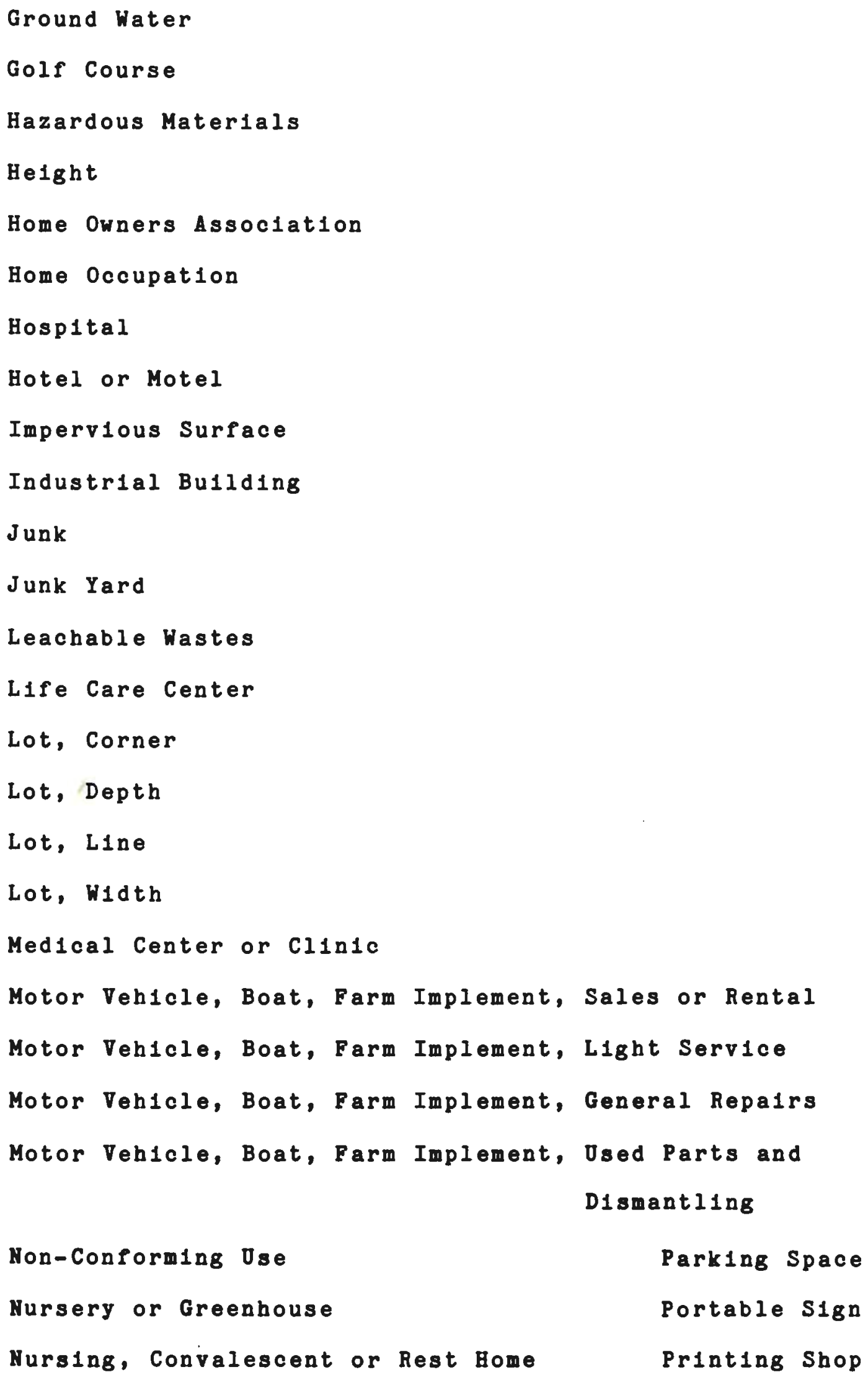




\section{Language}

In addition to the definitions, it is recommended that the following language should be added to address the uses not provided for:

4.01 Applicability of Use Regulations:

Except as provided in the Protective By-law or in the Zoning Enabling Act $\mathrm{Ch} 40 \mathrm{~A}$, no building, structure, or land shall be used except for the purpose permitted in the district as described in this section. Any use not listed shall be construed to be prohibited.

Permitted uses should be listed for quick easy reference. The following language is recommended:

4.02 Permitted Uses:

In the following Table of use regulations the uses permitted by right in said district shall be designated by the letter ( $Y$ ). Those uses that may be permitted by special permit in said district, in accordance with section seven, shall be designated by the letters (SP). Uses designated by the letter (N) shall not be permitted in said district. 
The Water Resource Protection Section (II-B) needs to be refined and supported with technical data (1e. Zone III Boundaries). The language should include determinations on sanitary landfills, junk yards, municipal sewerage treatment plants, all private sewerage treatment plants, motor vehicle salvage operations, underground storage of fuels, commercial painting, and wood preserving, finishing, stripping, or refinishing.

Regulations should be adopted for small private sewerage treatment facilities in the use regulations to display the location within the town where allowed. (See next section on the Board of Health Regulation)

Area regulations should be reformatted and expanded.

In order to address the future housing needs of Lakeville, the town should consider adding the following elements:

1. An inclusionary housing element (by special permit).

2. An accessory apartment element (by special permit).

3. A cluster or flexible site development (by special permit).

These Special Permits should be established in the zoning bylaws and fully explained in the Rules and Regulations for special Permits. (See Appendix C for examples of these By1aws) 
Certain zoning districts should be recommended for rezoning. These are the industrial land off Plerce Avenue, the Industrial parcel of of Bedford Avenue near Long Point Road, the commerclal land south of Clear Pond Road (the golf course), and the commerclally zoned property off of staples Shore Road.

Finaliy, a general site plan review section should be written with standard procedures and basic requirements which could be used by whichever board is acting as the special Permit Granting Authority. (A sample site plan review by-law is included in the appendix)

SUBDIVISION REGULATIONS

The Lakevilie Subdivision Rules and Regulations could use some minor additions in section I and III. They are as follows:

\section{Section I}

In section I, the following definitions are recommended to be included in the Rules and Regulations:
Aashto
Frontage
ACI
General Laws
Areas of Single Access
Large Trees 

Astm
Land Surveyor
Department Specification
Layout
Department Standards
Retention Facility
Detention Facility
Minor Residential st.
Emergency Access
Traveled Way
Engineer

2. Section III - Procedures for Submission and Approval of Plans

In section III, the following changes are recommended:

a. The language in Section a numbers 3,4 and 5 , should be changed from 14 to 21 days to comply with the recent changes in state law.

b. The following information should be required with definitive submittals:

1) A sheet showing the entire subdivision, 2 foot contour lines, and pre and post development drainage areas.

11) Proposed locations of dwellings and driveways with the percent of grade of sa1d ways. 
111) Location of sources of private water supply, nearest public water supply source, and existing septic systems in accordance with the Rules and Regulations of the Board of Bealth.

1v) Location of approved percolation test pits and deep observation pits, if any, in accordance with the Rules and Regulations of the Board of Health. Whether or not septic systems are proposed, general so11 $10 \mathrm{gs}$ and groundwater profiles shall be shown based on on-site observation pits and/or wells and/or percolation test. So1l logs shall be sufficient in detall to show the depth of organic matter, subso1l thickness, and depth to bedrock (up to $8^{\prime}$ ), as well as percent composition of soll and subsoll types. Locations of test pits shall be adequately distributed throughout the land area to the satisfaction of the Planning Board, providing at least 1 test hole per every two lots, and 1 per each 500' of proposed roadway. Additional test holes and test pit locations shall be developed through consultation with the Board, Town Englneer, and Town Planner as may be required by the specific conditions on the site. 
v) Location of proposed sewage disposal facilities with the elevation of the bottom of the leaching bed or trenches shown.

v1) Center lines of all proposed roads must be staked out and clearly marked with station numbers two weeks prior to public hearing.

v11) Contour information should be 2 feet instead of 5 foot.

v111) An erosion control and construction management plan should be submitted.

1x) Designation of the stump burial areas on the plans. 
BOARD OF HEALTH REGULATIONS

The Lakeville Board of Health Regulations generally reflect the State's Title 5 requirements. However, two suggestions would help the town direct growth into suitable areas, they are as follows;

1. Package Treatment Plant Regulation

Private package treatment plants are becoming more and more common. Therefore, it is important for the town to look for ways to control the locations of these facilities. It is important that there be supporting regulations in both the form of a use regulation of the Protective By-laws and in the Board of Health Regulations. The use regulation will state the locations within Lakeville where package treatment plants will be permitted, while the Board of Health regulation will support the use regulation with a statement restricting the placement of a facility in the ground water protection areas. (A model Package Treatment Plant regulation is included in Append1x E)

\section{Summer Cottage Conversion Regulation}

Lakev1lie has a considerable number of summer cottages, a great many of which are located on undersized lots. To prevent the cottages with poor septic systems from being 
converted to year-round dwellings and thus affecting nearby water supplies, it is suggested that Lakeville's Board of Health require inspection and certification of the on site septic system upon sale of the property. (A model septic system inspection regulation is included in Appendix E).

OTHER APPROPRIATE REGULATIONS

The only other regulation which could use some revision is the Zoning Board of Appeals requirements for site plans. It is recommended that all site plans contain the following additional information.

1. Locus scale should be 1 to 1,000 .

2. Show existing bulldings within 100 feet of the property I1nes.

3. Stop sight distance should be shown.

4. Wetlands and waterbodies

5. Actual on-site soils information including the percent composition of soll and subsoll types. Locations of said test pits should be on the proposed locations of drainage facilities. 
6. Proposed landscaping plans.

7. Proposed lighting.

8. Building elevations.

9. Proposed contours at 2 foot increments.

10. Parking, curbing and drainage. 
1. Burchell, Robert and Listokin, David, The Financial Impact Handbook, The Center for Pollcy Research, Piscataway, New Jersey. 1983.

2. Canter, Larry, Impact of Growth, Lewis Publishers, Inc. Chelsea, Michigan, 1984.

3. Calabro, John, and Associates, Freetown-Lakeville School District Study, Cohasset Massachusetts, 1988 .

4. Division of Employment Securities, 1986 Employment Wage Rates By Industry, Boston Massachusetts, 1987 .

5. E. J. Flynn Engineers, Inc., The Fair Shopping Plaza, (Riverside Park, MBTA Train station), Environmental Impact Report, Westboro, Massachusetts, 1987 .

6. HMM Associates, Great Ponds Industrial Park, Environmental Impact Report, Concord, Massachusetts, 1988 .

7. Institute of Transportation Engineers, 1985 Traffic Generation Tables, 1985 .

8. Lakeville Annual Town Reports, Lakeville Massachusetts, $1960-1980$.

9. Moor-Heder, Architects, Planners, Ocean Spray Cranberries Inc. Corporate Headquarters, Environmental Impact Report, Boston, Massachusetts, 1988 .

10. Massachusetts Census Bureau, 1985 State Census, Boston, Massachusetts, 1986 .

11. Robert, Snow, Means Co. Inc., Means Building Cost Data, Kingston, Massachusetts, 1986 .

12. Sasak1 Associates Inc., Raynham Hoods Commerce Center, Environmental Impact Report, Watertown, Massachusetts, 1986 .

13. SRPEDD, Lakeport Park, Massachusetts Community Development Action Grant Application, Taunton, Ma. 1983.

14. D.S. Federal Census Bureau, $1960=1980$ Federal Census, Washington D.C. 
APPENDICES 


\section{SRPEDD'S Methodology for Population Projections}

SRPEDD has developed a simple, straightforward methodogy to do population projections for any community using a microcomputer. The methodology is a compound cohort survival one and is "driven" by projections of new housing units expected to be built in a community. Since there is presently a housing shortage in Eastern Massachusetts, it is expected that virtually all units newly constructed will be occupied within a year or two of completion. Since many people in the area normally commute long distances to work, where the adult members of the household work will have only an indirect impact on where a household chooses to live.

The projections for population are based on the following components of population change:

1. Natural population change resulting from births and deaths. .-

2. Out-migration of individuals due to job changes, retirement, pursuit of higher education, lack of affordable housing, etc.

3. In-migration of people either moving into existing homes or into newly constructed units.

The specific values used to project each of these three components of population change were based on the following:

1. Fertility rates and survival rates for Bristol County or Plymouth County, depending upon the location of the community. These rates are based on 1980 data on births and deaths from the Massachusetts Department of Public Health and on the 1980 U.S. Census of Population, U.S. Bureau of the Census. The rates were generated by the Massachusetts Institute of Social and Economic Research (MISER) at the University of Massachusetts at Amherst. Survival rates are either five year or one year rates (depending on the level of detail of the projection) for males and females separately by age cohorts. Similarly, fertility rates used are five year or one year rates of births per thousand women by age cohort of mother, ages 15 to 44 .

2. Net in-migration and out-migration rates for each five year age cohort based on a comparison of the 1970 population of the community (according to the 1970 U.S. Census of Population) projected forward to 1980 (called the "1980 profected popula- tion") and the actual 1980 population of the community according to the $1980 \mathrm{U} . \mathrm{S}$. Census of Population. The 1970 population is "aged" forward to 1980 using county specific 1970 survival rates (generated by MISER) and actual births as reported by the Massachusetts Department of Public Health. The 1980 projected population was compared to 1980 actual population, cohort by cohort. The difference between the figures represents a net movement of people by age cohort in to or out of the community over the ten year period. Many communities show a net influx of new residents in all age cohorts except in the 20 to 24 age group and in some older age categories, generally over age 55 .

The increase between 1980 and 1980 in year-round occupied housing units as reported by the 1970 and $1980 \mathrm{U} . \mathrm{S}$. Censuses is used as the indicator of new household formation over the decade. The "net in-migrant" age cohorts are divided by the number of new households formed in the decade to produce an age profile of the "typical net migrant household." This term describes the 
average number of people (or fraction of people) of each age cohort who would be added to the town's population for each new household created. It should be noted that the "typical net migrant household" does not reflect the typical family moving into or out of the community. Rather it is a statistical average which combines the effects of in-migration, out-migration and changing family size. The remainder rates of net out-migrant age cohorts are computed separately. This methodology is discussed at the end of this

appendix.

Next, the 1980 population of the community is projected forward to 2005 using a model based on the aforementioned fertility and survival rates, as well as the number of new dwelling units expected to be built, which in turn generates the number of projected in-migrants. The rate of new housing starts expected in the future is based on an analysis of past residential building trends, on building permit data from the local building department, and on verbal input from the local building inspector and/or city or town planner. "Net outmigrant age cohorts are projected forward separately, independent of new housing construction, based on the remainder rate computed previously.

SRPEDD's computer model for population projections can be changed fairly easily in future years to reflect changing circumstances, such as actual fluctuations in building permits, or to project different future scenarios, such as high growth, low growth and middle growth rates.

Methodology of Deriving Net Out-migrant Age Group Remainder Rates:

The actual 1980 population in each net out-migrant age group is divided by the projected 1980 population to derive a ten year remainder rate for the group. $\left(\mathrm{R}^{10} \mathrm{~N}\right.$ where $\mathrm{R}^{10}$ = the 10 year rate and $\mathrm{N}=$ the specific age group.) To obtain a five year remainder rate, the square root of $R^{10} \mathrm{~N}$ was computed. This rate is applied specifically to net out-migrant age cohorts. 


$\begin{array}{lcc}\text { SUMMAFY OF HOUSING FROJELTIONS } \\ \text { ESTIMATED NEW HOUSING UNITS: } \\ 1980-1984=319 \\ 1985-1989=027 \\ 1990-1994 \quad= & 627 \\ 1995-1999 & = & 614 \\ 2000-2004 & = & 719 \\ & & 824\end{array}$

TABLE 12:

SUMMARY TABLE OF POPULATION PROJECTIONS:

5/4/88

\begin{tabular}{|c|c|c|c|c|c|c|}
\hline $\begin{array}{c}\text { AGE } \\
\text { COHOFT }\end{array}$ & $\begin{array}{l}1980 \\
\text { FOF. }\end{array}$ & $\begin{array}{l}1985 \\
\text { POF. }\end{array}$ & $\begin{array}{l}1990 \\
\text { POF. }\end{array}$ & $\begin{array}{l}1995 \\
\text { POF. }\end{array}$ & $\begin{array}{l}2000 \\
\text { POP. }\end{array}$ & $\begin{array}{l}2005 \\
\text { FOP. }\end{array}$ \\
\hline UNDER $\mathbf{5}$ & 363 & 387 & 477 & 543 & 620 & 708 \\
\hline $5-9$ & 470 & 457 & 576 & 661 & 758 & 867 \\
\hline $10-14$ & 592 & 591 & 695 & 809 & 934 & 1,071 \\
\hline $15-19$ & 559 & 632 & 671 & 773 & 900 & 1,038 \\
\hline $20-24$ & 337 & 451 & 510 & 541 & 624 & 726 \\
\hline $25-29$ & 435 & 389 & 555 & 612 & 660 & 761 \\
\hline $30-34$ & 541 & 603 & 721 & 879 & 991 & 1,095 \\
\hline $35-39$ & 449 & 648 & 816 & 929 & 1,122 & 1,270 \\
\hline $40-44$ & 340 & 499 & 749 & 913 & 1,043 & 1,253 \\
\hline $45-49$ & 289 & 347 & 514 & 761 & 927 & 1,059 \\
\hline $50-54$ & 320 & 316 & 404 & 567 & 819 & 993 \\
\hline $55-59$ & 293 & 339 & 362 & 446 & 613 & 868 \\
\hline $60-64$ & 274 & 300 & 361 & 383 & 470 & 636 \\
\hline $65-69$ & 246 & 282 & 332 & 388 & 416 & 507 \\
\hline $70-74$ & 179 & 232 & 279 & 322 & 376 & 406 \\
\hline $75-79$ & 114 & $15 \epsilon$ & 206 & 246 & 285 & 331 \\
\hline $80-84$ & 64 & 85 & 116 & 152 & 183 & 211 \\
\hline $85+$ & 66 & 72 & 88 & 115 & 150 & 187 \\
\hline $\begin{array}{l}\text { TOTAL } \\
\text { SEHOLDS } \\
\text { USEHOLDS }\end{array}$ & $\begin{array}{r}5,931 \\
1,891 \\
3.14\end{array}$ & $\begin{array}{r}6,785 \\
2,210 \\
3.07\end{array}$ & $\begin{array}{r}8,431 \\
2,837 \\
2.97\end{array}$ & $\begin{array}{r}10,039 \\
3,451 \\
2.91\end{array}$ & $\begin{array}{r}11,892 \\
4,170 \\
2.85\end{array}$ & $\begin{array}{r}13,986 \\
4,994 \\
2.80\end{array}$ \\
\hline
\end{tabular}


APPENDIX $\mathrm{B}$

\section{Larry Canter Impact of Growthth:}

Predicting Future Conditions with Project, Tables 11 \& 12 .

Methodolgy:

Determine the five year influx of workers to the community based on the following standards;

a) The communities percentage of the Region of Influence. In this case $1 / 2$ of $11 \%$, or $5.5 \%$.

b) The percentage of workers who will be accompanied by family. 25x unaccompanied, 75\% accompanied.

Unaccompanied workers demand on housing type:

Single family units: $15 \%, 3.0$ workers per unit Multi family units: 27x, 2.0 workers per unit Mobile homes: $\quad 38 \%, 2.5$ workers per unit Other unit types: $20 \%, 1.5$ workers per unit

Accompanied workers demand on housing type:

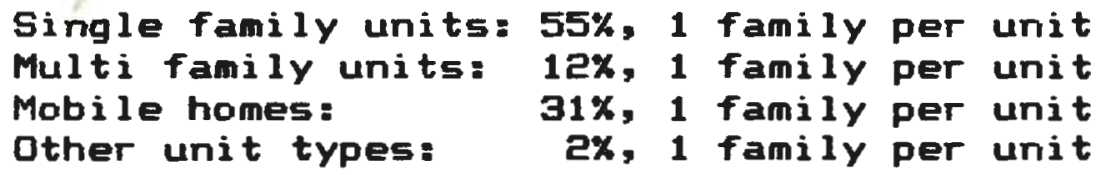

Example of Cummulative Housing Requirements for 1990 from Table 11:

\begin{tabular}{lcc} 
Housing & \multicolumn{1}{c}{$\begin{array}{c}\text { Unaccompanied } \\
\text { Workers }(25 \times)\end{array}$} & $\begin{array}{c}\text { Accompanied } \\
\text { Workers }(75 \%)\end{array}$ \\
\hline Single family units: & $(72+29)(.25)(.15) / 3+(72+29)(.75)(.55)=43$ \\
Multi family units: & $(72+29)(.25)(.27) / 2+(72+29)(.75)(.12)=12$ \\
Mobile homes: & $(72+29)(.25)(.39) / 2.5+(72+29)(.75)(.31)=27$ \\
Other unit types: & $(72+29)(.25)(.20) / 1.5+(72+29)(.75)(.02)=5$
\end{tabular}

The total is off by one as a result of rounding: $8 B$ 
The first copitol letter is the initial one of the soil nome. A second copital leirer, A, B, C, D, or E, shows the slope. Symbols without o slope letter ore those of neorly level soils or land iypes.

SYMBOL

NAME

AfA Agowam line sandy loom, 0 to 3 percent slopes

AfB Agowom line sondy loom, 3 to 8 percent slopes

AgA Agowom line sondy loom, silty subsoil vorioni, 0 10 3 percent slopes

AgB Agowom fine sondy loom, siliy subsoil voriant, 3 to $B$ percent slopes

AuA Au Gres and Worehom loomy sands, 0 to 3 percent slopes

AuB Au Gres ond Woreham loomy sands, 3 to 8 percent slopes

BoA Belgrode silt loom, 0 10 3 percent slopes

BoB Belgrode sils loom, 3 10 8 percent slopes

BbB Bernardston silt loom, 3 10 8 percent slopes

BbC Bernordston silt loom, 8 to 15 percent slopes

BcB Bernardsion very siony sill loom, 3108 percent slopes

BcD Bemordston very stony silt loam, 8 to 25 percent slopes

BdA Birdsoll silt loom, 0 to 3 percent slopes

B. Borrow lond, loomy moterial

BsA

BiA

COA

CoB

CoC

CoE

CbA

CbB

$\mathrm{CbC}_{\mathrm{b}}$

$\mathrm{CcD}$

DeA

DeB

Du

EnA

EnB

EnC

EsA

EsB

EsC

E,B

E,C

E,D

EuB

EvC

Borrow lond, sandy and gravelly moterials

Brockion loom, 0 ro 3 percent slopes

Brockton extremely stony loom, 0 to 3 percent slopes

Corver coorse sond, 0 10 3 percent slopes

Corver coorse sand, 3 to 8 percent slopes

Corver coorse sond, 8 to 15 percent slopes

Corver coorse sand, is to 35 percent slopes

Corver loomy coorse sand, 0 io 3 percent slopes

Corver loamy coorse sond, 3 to 8 percent slopes

Corver loomy coorse sond, 8 to is percent slopes

Corver and Gloucester soils, 8 to 35 percent slopes

Deerfield sondy loom, 0 io 3 percent slopes

Deerfield sandy loam, 3 io 8 percent slopes

Dune lond and Coosiol beoch

Enlield very fine sandy loom, 0 to 3 percent slopes

Entield very fine sondy loom, 3 to 8 percent slopes

Enfield very fine sandy loom, 8 to 15 perceni slopes

Essex coorse sondy $100 \mathrm{~m}, 0$ io 3 percent slopes

Essex coorse sondy loom, 3 10 8 percent slopes

Essex coorse sondy loom, 8 ro 15 percent slopes

Essex very stony coorse sondy loom, 3 to 8 percent slopes

Essex very stony coorse send, loom. B to 15 percent slopes

Essex very siony coarse scndy loom, 15 to 25 percent slopes

Essex exiremely stony coorse sondy loom, 3 to 8 percent slopes

Essex exiremely stony coorse sandy loom, 81025 percent slopes

Fr Fresh worer morsh

GoA

Go8

Gloucester fine sondy loom, firm substratum, 0 to 3 percent slopes

Gloweester fine sandy loom, firm substrotum, 3 to 8 percent slopes

GoC Gloweester fine condy loom, firm substratum, 8 io is percent slopes

GbA Gloucesier loomy sond, 0 to 3 porcent slopes

GbB Gloucester loomy sond, 3 io 8 percent slopes

GbC Gloucester loomy sand, 8 to 15 pereent slopes

G.B Gloucester very slony fine sondy loom, firm substrotum, 3108 percent slopes

GcC Gloucester very stony fine ssndy loom, firm substratum, 8 10 15 percent slopes

GcD Gloucesier very siony fine sjridy loom, firm subsirotum, 1 i ro 25 percent slopes

GdB Gloucester very stony loomy sand, 3 to 8 percent slopes

GdC Glowester very siony loomy sand, 8 to 15 percent slopes

GeB Gloucesier extremely stony isomy sond, 3 io 15 percent slopes

GeD Gloucesier extremely stony loomy sond, IS to 35 percent slopes
SYMBOL

NAME

HoA Hinckley drovelly Inaniy sond, : to 3 percent slopes HaB Hinckler gravelly loumy sond, 3 to 8 percent sloses HoC Hinckley grovelly loomy sond, $B$ to 15 percent slooes HoE Hinckley gravelly loomy sond, IS 1o 35 perceni stozes HoB Hollis-Chorlion fine sandy loams, 3108 percent slooes $\mathrm{HDC}_{\mathrm{C}}$ Hallis-Chorlion very rocky line sondy looms, 3 io is perceni slopes

MrC Hollis-Chorlion exiremely rocky fine sondy looms.

3 to 15 percent slopes

HrO Hollis-Chorlion extremely rocky fine sondy loams. is to 25 percent slopes

Mo

MeA Merrimac fine sandy loom, 0 10 3 percent slopes

MeB Merrimac line sondy loom, 3 to 8 percent slooes

MeC Merrimac line sandy loom, 8 to 15 percent slapes

MIA Merrimoc sondy loom, 0 to 3 percent slopes

MIB Merrimoc sondy loom, 3 to 8 percent slopes

MIC Merrimoc sondy loom, 8 to 15 percent slopes

MfE Merrimoc sondy loom, is io 35 percent slopes

Mu Muck, shollow

Mv Muck, deep

$\operatorname{NnA}$

NnB

Ninigret sondy loom, siliy subsoil voriont, 0 10 3 percent slopes

Ninigret sondy loom, siliy subso 1 voriant, 3 to 8 percent slopes

NoA Norwell sondy loom, 0 io 3 percent slopes

NoB Norwell sandy loom, 3 io 8 percent slopes

NpA Normell extremely stany sondy loam, 0 10 3 percent slopes

NoB Normell exiremely stony sondy loom, 3 to 8 percent slcoes

Pe Peor

PiA Pirtsiom sili loom, 0 io 8 percent slopes

PuB Piltsiown very stony silt loom, Z 10 15 perceni slopes

QuA Quonset sondy loom, 0 to 3 percent slopes

QuB Quonset sandy loom, 3 to 8 percens slopes

Q. Quonset sandy loom. 8 10 15 percent slopes

QuE Quonset sandy loam, 15 to 35 percent slopes

RoA Roynhom sili loom, 0 10 3 peicen: slopes

So

Sb

SeA

SdA

SeA

$\operatorname{SeB}$

SWA

SA

SgA

SgB

Td

T:A

WoA

WBA

WB

$\mathrm{WbC}$

weC

WnA

Whe

WhC

WnE
Soco very fint sandy loam

Sonded muck.

Scorboro sundy loom, 0 10 3 percent slopes

Scorboro line sondy loom, siliy subsoil variont, $0:=$ : percent slopes

Scituate sondy loom, 0103 percen: slopes

Scilvale sandy loam, 3108 percent slopes

Scipute very stony sandy loam, 0 ro 3 percent slose:

Scirware very stony sondy loom, I 10 percent slose:

Sciluote extremely stony sondy loam, 0 to 3 percen: slopes

Scirvate exiremely siony sondy loom, 3 10 8 percen. slopes

Tidal morsh

Tisbury very fine sondy loom, 0 ro 8 percent slopes

Wolpole fine sondy loom, siliy subsoil voriont, 0 to $\equiv$ percent slopes

Worwick fine sondy loom, 0 10 3 percent slopes

Worwick fine sondy loom, 3 to 2 gercent slopes

Worwick fine sondy loom, 8 to 15 percent slopes

Worwick very rocky fine sondy luam, 3 to 15 percent slopes

Windsor loomy sand, 0 to 3 perceris slopes

Windsor loomy sand, 3 to 8 percant stopes

Windscr loamy sand, 8 ro 15 percent slopes

Windsor loamy sand, 15 to 35 persent slopes 


\section{APPENDIX D}

Special Permit Regulations

1. Site Plan Review (7.01)

7.01.1 Statement of Purpose

The purpose of site plan review is to ensure that the design and layout of certain developments permitted as of right (or by special permit) will constitute suitable development and will not result in a detriment to the neighborhood or the environment.

In considering a site plan the Planning Board acting as the Special Permit Granting Authority (SPGA) shall assure:

1. Protection of adjacent areas against detrimental or offensive uses on the site by provision of adequate surface water drainage, buffers against light, sight, sound, dust and vibration, and preservation of light and air;

2. Convenience and safety of vehicular and pedestrian movement within the site and in relation to adjacent areas;

3. Adequacy of the methods of disposal for wastes;

4. Protection of environmental features on the site and in adjacent areas.

7.01.2 Projects Requiring Site Plan Review

No business or industrial building over 2,500 square feet shall be erected or externally enlarged, and no business or industrial use shall hereafter be established or expanded in ground area except in conformity with a site plan bearing an endorsement of approval from the (SPGA). The (SPGA) shall adopt regulations for carrying out its duties under this section.

7.01.3 Procedure

1. An applicant for site plan review under this section shall file with the SPGA 6 copies of each of an application and a site plan. The site plan shall be prepared by an engineer, architect, or landscape architect.

2. The following information shall be required by the applicant for site plan review:

a. locus plan; 
b. location of structures within 100 feet of property lines;

c. existing and proposed buildings, showing setbacks from property lines;

d. building elevations;

e. existing and proposed contour elevations in two-foot increments;

f. parking areas, driveways, and facilities for pedestrian movement

g. drainage system;

h. utilities and lighting;

i. landscaping, including trees to be removed and retained;

j. loading and unloading facilities;

k. provisions for refuse removal;

1. existing and projected traffic volumes from the site and effect on the local road network;

m. drainage calculations and type of soil;

n. other information as may be necessary to determine compliance with the provisions of this bylaw.

3. The Planning Board acting as SPGA shall examine the following concerns in reviewing the site plans of the proposed development :

a. proper drainage of the property;

b. safe access to the development, minimizing the number and width of curb cuts;

c. acceptable design and layout of ways, streets, and parking areas;

d. that the projected traffic encreases to the local road(s) is within the capacity of the existing network for both daily and peak hour volumes;

e. proper lighting design for parking areas;

f. that proposed use(s) will not have a detrimental effect on the abutting neighborhoods or natural environment; 
g. complies with the Lakeville Master Plan.

4. The SPGA shall within five days of receipt transmit to the planning board, the building inspector and the conservation commission six (6) copies of the application and site plan. The boards receiving these copies shall have up to 30 days to make recommendations to the SPAG. 
2. Aquifer Protection District By-law (7.02)

7.02.1 Statement of Purpose

The purposes of this by-law are to protect public health from the contamination of existing and potential public and private water supplies and to protect the general welfare by preserving limited water supplies for present and future use.

7.02.2 Delineation of Ground Water Protection District

1. For the purposes of this by-law there is hereby established within the town of Lakeville an overlay district consisting of certain ground water protection areas, including aquifers and recharge areas, which are delineated on the zoning map dated, entitled "Aquifer Protection District, Town of Lakeville" and which shall be considered as superimposed over other districts established by the zoning by-laws of this town. This map, as it may be amended from time to time, is on file with the office of the town clerk, and, with any explanatory material thereon, is hereby made a part of this by-law.

2. Where the bounds of the Aquifer Protection District, as delineated on the Aquifer Protection District map, are in doubt or in dispute, the burden of proof shall be upon the owners of the land in question to show where they should properly be located. At the request of the owners, the town may engage a professional hydrogeologist or soil scientist to determine more accurately the location and extent of an aquifer or recharge area and may charge the owners for all or part of the cost of the investigation.

7.02.3 Permitted Uses

Within the Aquifer Protection district, the following uses are permitted, provided that all necessary permits, orders and approvals required by local, state and federal law are also obtained:

1. conservation of soil, water plants and wildlife;

2. outdoor recreation, not involving the use of motor vehicles or motor boats, including boating, fishing, nature study and hunting where otherwise legally permitted;

3. foot, bicycle and horse paths and bridges;

4. maintenance and repair of any existing structure, provided there is no increase in impervious pavement;

5. normal operation and maintenance of existing water bodies and dams, splash boards, and other water control, supply and conservation devices; 
6. residential development, permitted in the underlying district, provided that no more than 10 percent of a building lot (including the portion of any new street abutting the lot) is rendered impervious and that in unsewered areas minimum required lot area per dwelling unit shall be one acre or the minimum required in the underlying district, whichever is greater.

7. farming, gardening, nursery, conservation, forestry, harvesting and grazing uses, provided that fertilizers, herbicides, pesticides, manure and other leachable materials are not stored outdoors and that the use of such materials in non-domestic applications is approved by spēêlal permit.

7.02.4 Prohibited Uses

Within the Aquifer Protection District, the following uses are prohibited:

1. storage of liquid petroleum products of any kind except for storage in a free-standing container within a bullding of fuel for the heating of that building;

2. disposal of hazardous materials;

3. storage of hazardous wastes, as defined in Mass. Gen. Laws $\mathrm{Ch} .21 \mathrm{C}$, as amended;

4. disposal of solid wastes other than brush or stumps;

5. disposal of leachable wastes except for subsurface waste disposal from one-family residential units.

6. storage of road salt or other deicing chemicals;

7. disposal of snow that contains defcing chemicals and that has been brought in from outside the District;

8. Industrial uses that discharge process wastewater on site;

9. outdoor storage of fertilizers, herbicides and pesticides, and outdoor uncovered storage of manure;

10. animal feedlots;

11. dry cleaning establishments;

12. chemical and bacteriological laboratories;

13. metal plating establishments; 
14. boat and motor vehicle service, washing and repair establishments;

15. junk and salvage yards;

16. the rendering impervious of more than $10 \%$ of any lot;

17. mining of land except as incidental to a permitted use.

7.02.5 Special Permit Uses

The following uses may be permitted by a special permit from the Special Permit Granting Authority (SPGA), under such conditions as the SPGA may require:

1. commercial and industrial activities permitted in the underlying district and involving the manufacture,

2. the application of pesticides for uses that are nondomestic provided that all necessary precautions shall be taken to prevent hazardous concentrations of pesticides in the water and on the land within the Aquifer Protection District as a result of such application, such precautions to include, but not be limited to, erosion control techniques, the control of runoff water (or the use of pesticides having low solubility in water), the prevention of volatilization and redisposition of pesticides and the lateral displacement (i.e. winddrift) of pesticides; and

3. the application of fertilizers for uses that are nondomestic provided that such application shall be made in such a manner as to minimize adverse impacts on surface water and ground water due to nutrient transport and deposition or sedimentation;

4. nonconforming uses existing at the effective date of this by-law may be expanded only to the extent allowed by special permit, and then only if the proposed expansion shall not be more detrimental to the water supply than the existing use;

5. one nonconforming use of a structure, building, or property may be changed to another nonconforming use only by special permit and only if the proposed new use shall be less detrimental to ground water than the prior use;

6. If any nonconforming use ceases for any reason for a period of two years, such land and bulldings shall thereafter be used and developed only in accordance with the terms of this Aquifer Protection By-law;

7. wherever a nonconforming use is changed to a permitted use, such use shall not thereafter revert to a nonconforming status. 
7.02 .6

Procedures for Issuance of Special Permits

*See procedures for Special Permits under MGL 40A, Section 9. 
3. Residential Cluster Development (7.03)

7.03.1: Statement of Purpose:

A residential cluster development may be authorized by special permit in the Town of Lakeville in order to achieve the following objectives:

1. Flexible and sensitive site design;

2. Promotion of measures to ensure compatibility of growth and sensitivity to the natural environment;

3. Enhancement of residential and community amenities by provision of open space;

4. Promotion of economical and efficient use of roads, water and sewer lines and other related infrastructure;

5. Promotion of diverse and energy-efficient housing at a variety of costs; and

6. Protection of water bodies and supplies, wetlands, floodplains, agricultural lands, wildlife, and other natural resources.

7.03.2 Definition and Applicability:

Residential cluster development means a residential development in which the buildings and accessory uses are clustered together into one or more groups separated from adjacent property and other groups within the development by intervening open land, unless deemed otherwise by the special permit granting authority.

A Residential Cluster Development shall conform to the following conditions:

1. Contain a minimum tract size of twenty (20) acres.

2. The maximum number of dwelling units shall conform to the existing zoning area requirements of said property. Except for proposals which include an Inclusionary Housing Element. (See 7.03.3)

3. No more than four (4) dwelling units may be attached within a building.

4. There shall be a minimum width of 30 feet of buffer area between attached cluster buildings, and a minimum width of 50 feet of buffer area between any clusters and the abutting property lines or public ways. These buffer areas are not to be counted as a portion of the dedicated open space. These buffer areas shall provide suitable landscaping to screen the cluster buildings from each other, abutters, and the street year round. 
5. Streets, ways, parking, drainage and utilities shall be designed and constructed in accordance with the SPGA rules and regulations for residential cluster developments.

6. Required Open Land:

a. At least $40 \%$ of the tract (exclusive of land set aside for roads and parking) shall be open lands. At least $75 \%$ of the open land shall be suitable for passive or active recreations use, and shall not be wetlands or land subject to seasonal flooding.

b. The open land, and such other facilities as may be held in common, shall be conveyed to one of the following, as determined by the Planning Board, subject to the following guidelines:

In general, valuable natural resource land, such as wetlands not suitable for any public use or suitable for extensive public recreational use, should be conveyed to the Town or to a trust; whereas land which will be principally used by the residents of the cluster should be conveyed to a homes association.

i. To a corporation or trust comprising a home association whose membership includes the owners of all lots or units contained in the tract. The developer shall include in the deed to owners of individual lots beneficial rights in said open land, and shall grant a conservation restriction to the Town of Lakeville over such land pursuant to General Laws, Chapter 184 , Sections 31-33, to ensure that such land be kept in an open or natural state and not be built upon the residential use or developed for accessory uses such as parking or roadways. This restriction shall be enforceable by the Town through its Conservation Commission in any proceeding authorized by Section 33 of Chapter 184. In addition, the developer shall be responsible for the maintenance of the common land and any other facilities to be held in common until such time as the homes association is capable of assuming said responsibility. In order to ensure that the association will properly maintain the land deeded to it under this section, the developer shall cause to be recorded at the County Registry of Deeds a Declaration of Covenants and Restrictions which shall, at a minimum, provide for the following:

1. Mandatory membership in an established homes association as a requirement of ownership of any lot in the tract.

2. Provisions for maintenance assessments of all lots in order to ensure that the open land is maintained in a condition suitable for the uses approved by 
the homes association. Failure to pay such assessment shall create a lien on the property assessed, enforceable by either the homes association or the owner of the lot.

3. Provision which, so far as possible under the existing law, will ensure that the restrictions placed on the use of the open land will not terminate by operation of law.

ii. To a nonprofit organization, the principal purpose of which is the conservation of open space. The developer shall grant a conservation restriction as set out in (a) above.

iii. To the Conservation Commission of the Town for park or open space use, subject to the approval of the Selectmen, with a trust clause ensuring that it be maintained as open space.

7. Subject to the above, the open space may be used for recreational purposes, including golf courses, riding trails, tennis courts, gardens, swimming pools, and temporary structures.

8. A site plan and supporting data as required by the rules and regulations for residential development.

7.03.3 (Open)

7.03.4 Administrative Procedures:

The Planning board as the Special Permit Granting Authority (S.P.G.A.) for Residential Cluster Developments shall adopt rules relative to the issuance of spacial permits and file a copy with the Town Clerk.

\subsubsection{Review Procedures:}

The S.P.G.A. shall review all applications for a residential cluster development to determine the sensitivity of the site to the following criteria:

1. Compatibility with existing developments;

2. Compliance with adopted plans;

3. Acceptable design and layout of ways, streets, drainage and paving;

4. That the projected traffic increase to the local road(s) is within the capacity of the existing network;

5. Compliance with environmental standards; and

6. Appropriateness of building and site design. 
1. Statement of Purpose:

An inclusionary housing element may be authorized as a condition to a Residential Cluster Development Special Permit by the Planning Board in the Town of Lakeville in order to achieve the following objectives:

a. Promotion of different types of housing stock within Lakeville.

b. To allow residents of different ages and income to remain in Lakeville.

c. To assist the town in achieving a permanent percentage of subsidized housing stock for the town's residents.

2. Definition and Applicability:

An Inclusionary Housing Element is a provision which allows an applicant to request an increase in the density of a Residential Cluster Development proposal from the Planning Board in order to create affordable units within the development.

An Inclusionary Housing Element proposal shall conform to the following conditions:

a. Applicant shall submit the Inclusionary Housing Element proposal with supporting information as part of the submittal for a Residential Cluster Development Special Permit.

b. The Inclusionary Housing Element proposal shall comply with the requirements for Residential Cluster Developments (See Section 7.03.02) and the requirements set forth in rules and regulations for Residential Cluster Development Special Permit.

c. No Inclusionary Housing Element proposal shall be allowed in areas delineated for water resource protection (Zone III).

d. The level area used for the calculation of the proposed density shall not include land required for open space and buffer zones (See 7.03.02.4 and 703.02.6).

e. 30,000 square feet is the minimum lot area allowed for calculation of the density of an Inclusionary Housing element.

f. All Housing units must contain a minimum size of 800 square feet of living area. (This provision does not apply to single family detached dwelling units.) 
g. Ten ( $10 \%)$ percent of the developments total units shall be donated to the Lakeville Housing Authority to be used for subsidized housing.

h. Units for the Housing Authority shall include a mix of one, two and three bedrooms as well as Handicapped units. The Planning Board shall determine the amount and types of units based on the Recommendation of the Housing Authority.

i. The units donated to the Housing Authority shall be dispersed throughout the site and be of the same design and construction of the marked rental units.

j. The Planning Board shall not approve more than one Inclusionary Housing Proposal for the town, during each calender year.

3. General Procedures:

The Board should review the Inclusionary Housing Element as a Component of the Residential Cluster Development applicant which may be granted as a condition to the Special Permit. An applicant for a residential cluster proposing a density bonus under this provision shall submit a site plan showing the development as permitted under Sect 50 7.03 (Residential Cluster Development) and a separate site plan, including all other required information, showing the developmnt as proposed with the density bonus under Section 7.03 .03 (Inclusionary Housing). 
5. Accessory Apartments (7.04)

7.04.1 Statement of Purpose

The purpose of this bylaw is to provide housing opportunities in existing single residences; to permit the economic use of existing large single homes and non-residential buildings by providing an opportunity for income assistance to owners/occupants; to encourage investment in renovation and maintenance; and to conserve property values and the visual character of residential districts.

7.04.02 District Designations

See Section 4, Use Regulations

7.04.03 Special Permit Uses

The Zoning Board of Appeals, acting as the special permit granting authority, may grant a special permit for the construction of accessory apartments, in the following c1rcumstances:

1. The division of a single family dwelling into two independent dwelling units.

2. The construction of one to four independent dwelling units in a building not presently used for residential purposes in which the structure will be used for a mix of residential and non-residential purposes.

7.04.04 Dimensional Requirement

1. The lot area after the construction of an accessory apartment (s) shall be at least 70,000 square feet per dwelling unit, and the subject lot is suitable for the proposed use.

2. Special Permit Granting Authority shall require a adequate provision for water and sewer.

3. The accessory apartment(s) shall not contain less than 700 square feet of living space per dwelling unit.

4. The accessory apartment shall occupy no more than forty percent (40\%) of the floor area of the building. This provision shall not apply to accessory apartments located in non-residential buildings.

5. The SPGA may limit the maximum number of occupants and the maximum area of an accessory apartment(s) to insure that the accessory apartment $(s)$ is clearly subordinate to the principal single family dwelling. 
Applicants for a special permit shall meet the following conditions :

1. Accessory apartments are only permitted in buildings in existence at the time the Zoning Bylaw was adopted.

2. No accessory apartments shall be constructed unless the lot contains two off-street parking spaces per dwelling unit. All off-street parking spaces shall be paved with a hard, dust free surface. All off-street parking space shall be directly accessible to a street, except where the SPGA determine that the strict enforcement of this provision would be detrimental.

3. Except for safety features required by state regulations, the creation of an accessory apartment(s) shall not result in any significant changes to the exterior of the building and shall preserve the appearance of a single family residence. No major additions or changes may have been made to the building exterior subsequent to

4. A site plan and supporting data as required by the rules and regulations for accessory apartments.

\subsubsection{Administrative Procedures}

The SPGA shall adopt rules and regulations relative to the procedures to be followed, and the criteria and performance standards for the evaluation of special permits, and may provide for informal pre-application hearings for the consideration of preliminary plans. The rules and regulations shall specify any additional information the SPGA deems necessary to make it's review, including the quantities, content, and scale of maps to be presented. 


\section{APPENDIX E}

\section{BOARD OF HEALTH REGULATIONS}

\section{INSPECTION OF SEPTIC SYSTEMS}

\section{REGULATION :}

The inspection of existing Commercial and Residential sewage disposal systems shall be the responsibility of the owner prior to Real Estate Transfers.

PURPOSE:

To determine and to protect the Public Health from potential and present sources of pollution to ground water or surface water from existing sewage disposal systems, the Board of Health requires that the owner(s) of a developed property in Lakeville, Massachusetts order an Inspection of the existing septic system prior to the time of transfer of that property.

For the purpose of this regulation, reference is made to the standards and provisions of title $V$ of the State Sanitary Code, and to the existing regulations of the Lakeville Board of Health Regulations for sub-Surface Sewage Disposal.

After an inspection by a Registered Professional Engineer or Santarian that Engineer or Sanitarian shall file a Certificate of Compliance/Inspection Form with the Board of Health with copies to the Seller, Buyer, and Assessor's office stating whether the system is in Good, Marginal, or Failed condition.

If it is determined by the Board of Health that the system constitutes a danger to the Public Health, the board shall order the owner to make repairs/replacement of the system. If the work is not completed within the time designated by the Board of Health, the board may impose fines and/or repair/replace the system at the expense of the owner. Regulations of the Board of Health shall apply to all repairs or replacement of the system.

In additional to any other remedy, the Board of Health may take any enforcement action deemed appropriate, including but not limited to Criminal Prosecution, to seek a fine in accordance with Chapter 111 , Section 31, or Civil Action in the Courts of the commonwealth for injunctive relief or money damages or both, or both Civil and Criminal enforcement.

The Board of Health is authorized to issue Notices of Violation, Cease and Desist orders, or other Administrative enforcement orders to compel compliance with the terms of these Regulations.

This regulation, however, shall not be effective at the conveyance or devise of the property to the Surviving Spouse or any of the Decendants 
of the Property Owner and further, shall not apply to a sale under power of sale contained in a bonafide mortgage effecting the property. 


\section{INSTRUCTIONS :}

1. The Inspection by the Registered Englneer or Sanitarian should take place no more than ninety (90) days nor less than thirty (30) days prior to the transfer of property. The Board of Health must receive the Inspection Certificate Form within sever (7) days of the Inspection. In addition, the copies must be given to the Owner, to the Buyer, and the Assessor's office at that time. Inspection/Certificate Forms are provided by the Board of Health.

2. If the Inspection finds evidence of sewage on the surface or draining into any waterways or wet lands, the board of Health shall determine within fourteen (14) days after receiving the Inspection Forms, whether or not the system constitutes a danger to the Public Health and should be repaired/replaced. By the end of the time period, the Board of Health, or its Agent, must notify the Owner by Certified Mail whether or not the system must be repaired/replaced.

3. If the Inspection finds the system to be "Marginal", the Board of Health will decide within fourteen (14) days after receiving the Inspection Form whether or not the system constitutes a danger to the Public Health and should be repaired/replaced. Before the end of that time period the Board of Health, or its Agent, shall notify the Owner by Certified Mail whether or not the system must be repaired/replaced.

4. The amount of allowable time for the repair or replacement will be determined by the Board of Health and will be contained in the letter of notification to the Owner. A copy of the Notification will be filed at the Town Assessor's Office.

5. If repair/replacement is required, upon completion of that work, the Health Agent must inspect and signify, in written form, that satisfactory repairs have been made.

6. Any system having been installed and having received final inspection approval by the Board of Health or its Agent within 24 months, shall be exempt from this Regulation, provided additional living space has not been added to the residence in question. 


\section{REGULATION OF SMALL WASTEWATER TREATMENT FACILITIES}

The Board of Health of the Town of Lakeville, Commonwealth of Massachusetts, acting under the authority of Chapter 111, Section 31 of the Massachusetts General Laws and any amendments and additions thereto, and by any other power thereto enabling, and acting thereunder and in accordance therewith, have, in the interest of and for the preservation of the public health, duly made and adopted the following regulations effective upon publication.

DESIGN, OPERATION, AND MAINTENANCE

OF SMALL WASTEWATER TREATMENT FACILITIES

\section{$1.00 \quad$ Permit Requirements}

1.10 Disposal Works construction Permit

No system or facility to be used for treating, neutralizing, stabilizing, or disposing of wastewater from homes, public buildings, commercial or industrial buildings, or any types of establishments, shall be located, constructed, installed operated, altered, or repaired until a DISPOSAL WORKS CONSTRUCTION PERMIT for such shall have been issued by the BOARD OF HEALTH. No construction of any building or facility which rely upon such wastewater system or facility shall be allowed until a DISPOSAL WORKS CONSTRUCTION PERMIT shall have been issued by the Board of Health.

Such system or facility as regulated herein shall include, but not be restricted to, SEWERS serving such facility, WASTEWATER PUMPING STATIONS, WASTEWATER TREATMENT WORKS, ALL WASTEWATER TREATMENT OPERATIONS, SLUDGE TREATMENT AND MANAGEMENT, DISINFECTION, ADVANCED WASTE TREATMENT, SUBSURFACE DISPOSAL AND LAND TREATMENT, WASTEWATER RECYCLING AND RE-USE.

Such system or facility as regulated herein shall be referenced as SMALL WASTEWATER TREATMENT FACILITY.

1.20 Certificate of Compliance and Operations Permit

No SWWTP as permitted herein shall be placed in service, nor shall new buildings or facilities or additions to existing buildings or facilities which rely upon such SWWTP be occupied or used until the BOARD OF HEALTH has issued a CERTIFICATE OF COMPLIANCE AND OPERATIONS PERMIT.

\subsection{Service Area and Limitations}

The SWWTP shall not serve a volume of sewage flow from any subject project in excess of the aggregate volume that would be generated by each lot, which could have constructed upon it, a septic system installed and operated in full compliance with Title 5, the State Environmental Code and the regulations of the Board of Health. 
In order to provide adequate wastewater treatment capacity in the event of a failure of said SWWTP, each residential lot connected to a SWWTP shall be shown to have reserve area adequate to construct a septic system in accordance with Title 5, the State Environmental Code and the regulations of the Board of Health.

\section{$2.00 \quad$ Submittals}

2.10 Applications, Reports, Plans, Data, Documents

A copy of all applications, reports, plans, specifications, data, and supporting documents required by these regulations and by the regulations of any other agency in connection with the approval or operation and maintenance of the subject facility shall be submitted to the Board of Health. In the case of requests for a Board of Health action, such materials shall be submitted a minimum of 90 days prior to the date upon which an action by the Board of Health is desired. In the case of submittals to other agencies, all material shall be submitted to the Board of Health at the time of submittal to that agency. A Board of Health Disposal Works Construction Permit will not be issued prior to approval by the Massachusetts Department of Environmental Quality Engineering. Other submittals shall be made in accordance with schedules as specifically designated by the Board of Health.

3.00 Other Regulations and Guidelines

3.10 Federal, State, and Local Regulations

The applicant for any SWWTP shall comply with all applicable Federal, State, and Town or City regulations as existing and may be amended from time to time. All data, reports, and plans designated by those regulations shall be submitted to the Board of Health. All data required by these regulations shall be promptly submitted to the Board of Health in a timely fashion.

3.20 Standards for Design, Operations, and Maintenance

These regulations herein do not and are not intended to cover all aspects of engineering design, operation, and maintenance of SWWTPs. Rather they outline the specific BOARD OF HEALTH INTERESTS AND POLICIES that may not be adequately reflected in other existing regulations, policies, and manuals. Where local regulations or specifications herein are more strict, they shall prevail. Where regulations or specifications or guidelines of other political subdivisions or agencies of jurisdiction or as included herein are more strict, they shall prevail.

The applicant shall specifically follow the following regulations and guidelines which address the various aspects for the systems and facilities considered herein, and are incorporated as a part of these regulations by reference where applicable.

MASSACHUSETTS DEPARTMENT OF ENVIRONMENTAL QUALITY ENGINEERING (DEOE) 
Guidelines for the Design, Construction, Operation, and Maintenance of Small Sewage Treatment Facilities with Subsurface Effluent Disposal Title 5 - The State Environmental code

Ground Water Quality Standards

Ground Water Discharge Permit Program

NEW ENGLAND INTERSTATE WATER POLLUTION CONTROL COMMISSION (NEIWPCC)

Guidelines for the Design of Wastewater Treatment Works

1980 Edition TR-16

WATER POLLUTION CONTROL FEDERATION (WPCF - MPO \#8)

MANUAL OF PRACTICE NO. 8 - Wastewater Treatment Plant Design

RECOMMENDED STANDARDS FOR SEWAGE WORKS: GREAT LAKES - UPPER

MISSISSIPPI RIVER

BOARD OF STATE SANITARY ENGINEERS ( $t$ he Ten State Standards)

WATER POLLUTION CONTROL FEDERATION (WPCF MPO - 9)

MANUAL OF PRACTICE NO. 9 - SEWER DESIGN AND CONSTRUCTION

(Same as AMERICAN SOCIETY OF CIVIL ENGINEERS Manual and Reports on

Engineering Practice No. 37)

UNITED STATES ENVIRONMENTAL PROTECTION AGENCY, MUNICIPAL ENVIRONMENTAL LABORATORY, "Design Information on Rotating Biological Contractors (EPA-60012-84-106)

For situations not covered by these regulations and guidelines, good engineering practice, as determined by the Board of Health, shall govern.

While it is recognized that certain modifications or exceptions may be necessary where justified in unusual situations, any such modifications or exceptions shall only be provided by application for variance to the Board of Health. Any variances to these regulations issued by the Board of Health shall comply with the provisions outlined in the State Environmental Code, Title 5.

4.00 General Project Planning Requirements

Certain basic principles shall be considered early in the planning and design process in order to ensure that the SWWTP development process will meet all requirements.

\subsection{Environmental Compatibility}

The plans for the proposed system or facility shall take into account all aspects of public health and environmental quality protection. Efforts shall be taken to preserve water supply, private property, wetlands, wildlife habitat, recreational sites, historic sites, and natural beauty.

The design shall be prepared so as to have the least possible adverse impact on the public health and the environment. 
The project proposal shall include evidence that the wastewater system or facility will result in the least adverse impact on the public health or the environment as compared with other possible wastewater management alternatives for the project.

4.20 General Discharge and Treatment Requirements

No discharge from a SWWTP shall result in degradation of ground or surface waters in a manner inconsistent with their proposed use. There shall be compliance with all applicable water quality standards. The existing characteristics of the recelving waters must be considered to ensure compliance. There shall be no discharge into any wetland, stagnant waters, lakes, or streams.

4.30 Hydrogeological Investigation

The applicant shall submit a hydrogeological survey report, prepared by a qualified geotechnical engineer or hydrogeologist, to show the impact of the subsurface discharge of the SWWTP on ground water. The report shall include a determination of the flow direction, contaminant levels, extent of wastewater discharge plume, ground and surface waters affected, and any interaction with water supply, public or private. This analysis shall be performed for the SWWTP design plan and also for any other viable wastewater treatment or disposal strategy for the project to be served.

4.40 Wetlands and Flood Plains

No portion of the SWWTP shall be within 100 feet of wetlands or the "100 year" flood plain.

No portion of the subsurface disposal works for a SWWTP shall be located less than 200 feet from a wetland or the 100 year "Flood Plain". No component of the treatment plant, except for underground plping, shall be constructed less than two (2) feet above the high water level in any area subject to flooding. Such distances are considered "minimum" and may be increased by the Board of Health if site specific conditions warrant.

4.50 General Siting and Design Requirements

SWWTP design shall include attenuation of odor or noise problems, and shall satisfactorily address the general aesthetic appearance, to both protect the operator and to satisfy neighborhood environmental requirements.

\subsection{Distances}

No portion of the SWWTP shall be located less than the following distances stated to the components listed as follows: 


\section{MINIMUM ACCEPTABLE SEPARATION DISTANCES IN FEET}

$\begin{array}{lccccc}\text { COMPONENT } & \begin{array}{c}\text { Plant } \\ \text { Buildings }\end{array} & \begin{array}{c}\text { Pumping } \\ \text { Station }\end{array} & \begin{array}{c}\text { Subsurface } \\ \text { Tank }\end{array} & \begin{array}{c}\text { Leaching } \\ \text { Area }\end{array} & \begin{array}{c}\text { Sewer or } \\ \text { Force Main }\end{array} \\ \text { Well* } & 100 & 100 & 100 & 400 & 50 \\ \text { Water Supply Line } & -- & 10 & 10 & 25 & 10 \\ \text { Dwelling Unit } & 100 & 50 & 50 & 100 & 50 * \\ \text { Subsurface Drain } & -- & 25 & 25 & 100 & 5 \\ \text { Property Boundary } & 150 & 50 & 50 & 200 & 50 \\ \text { Surface Water* } & 100 & 100 & 100 & 200 & 50 \\ \text { Wetland* } & 100 & 100 & 100 & \end{array}$

*This distance may be required to be greater if the hydrogeological evaluation indicates that contamination will occur at the stated distance.

4.60 Ultimate Disposal of Sludge and Solids

Provision for final or ultimate disposal of sludge and solids shall be clearly indicated and established. The estimated quantity must be stated. If sludge and solids are to be disposed of off-site, the final destination must be established prior to issuance of any permit. The applicant must demonstrate, to the satisfaction of the Board of Health, that the destination for the sludge and solids is in compliance with all applicable federal, state, and local regulations and also that it will reliably be available for such purpose for the length of time that its use is required for the SWWTP.

If disposal is to be on-site, it must comply with the terms of the section above "General Discharge and Treatment Requirements".

4.70 Treatment Plant Reliability

The SWWTP shall be planned and designed so as to provide for maximum reliability at all times. The facility shall be capable of operating satisfactorily during power failures, flooding, peak loads, equipment failure, and maintenance shutdowns. Such reliability shall be obtained through the use of various design techniques which will result in a facility which is virtually "Fail-Safe".

Multiple units or dual compartments with unit drains shall be provided for all processes, including disinfection facilities, so that draining, cleaning, repairing, or replacing, and other maintenance can be provided without omitting any treatment processes.

4.80 By-Passes and Overflows

No by-passes, either upstream of or at the SWWTP shall be permitted.

4.90 Disinfection

Disinfection of the SWWTP effluent by ultraviolet irradiation or zonation shall be required. 
5.00 Subsurface Disposal Facilities

5.10 Ground Water

The bottom interface of any subsurface disposal or leaching facilities shall be located a minimum of $f$ ive (5) feet above the MAXIMUM ELEVATION OF THE GROUND WATER OR SATURATED SOIL ZONE. This elevation shall include consideration of the mounding effect of the ground water caused by the discharge of the SWWTP effluent. Such analysis shall be calculated using generally acceptable analytical or numerical methods. When geologic conditions permit, the "Hantush" formula and procedure may be used. When the assumptions of that procedure cannot be met to derive a reliable result, it shall be required to utilize such method as finite difference equations for ground water flow and elevation.

\subsection{Distance to Bedrock}

The bottom interface of any subsurface disposal or leaching facilities shall be located a minimum of ten (10) feet above the elevation of bedrock or impervious soll layer. Impervious soll shall be defined as having a percolation rate of greater than 20 minutes per inch.

5.30 Thickness of Permeable Soll

A depth of at least five (5) feet of naturally occurring permeable soil shall be maintained below the bottom of the leaching area. To be considered permeable, the soil shall have a percolation rate of 20 minutes per inch or less.

6.00 Sewers

The lateral sewer system serving the SWWTP shall be of a design and construction in accordance with Water Pollution Control Federation Manual of Practice 9 . Adequate capacity shall be provided for peak flow rates and shall provide for a cleansing velocity of at least two (2) feet per second at 75 per cent of the estimated peak discharge. For low service connection areas, peak flow rate shall be calculated by the fixture unit method as described in MOP \#9. The minimum pipe size allowed shall be eight ( 8 ) inches in diameter.

7.00 Ground Water Monitoring

7.10 Installation

The permittee shall install, at a minimum, ground water monitoring wells in accordance with the following:

One up-gradient cluster of three monitoring wells

Two down-gradient clusters of three monitoring wells

One monitoring well for ground water level only near the center of the leaching works. 
Screen depths for the cluster wells shall be set at elevations such that at least two screen depths will yield samples at time of seasonal low ground water (e.g. September sampling period)

Such locations shall be as approved by the Board of Health and as indicated appropriate from the results of the hydrogeological investigation. Monitor wells shall be installed and in place prior to issuance of the CERTIFICATE OF COMPLIANCE AND OPERATIONS PERMIT.

7.20 Ground Water Elevation

The permittee shall determine and provide the Board of Health with elevations of the water table to the nearest one-hundredth of a foot in all monitor wells on a monthly basis. ..

8.00 Effluent Limits and Testing Requirements

Effluent limitations shall be as required by DEQE regulations for Class I and Class II ground waters. All ground waters are considered to be in this classification unless proved to be otherwise following procedures set forth by DEQE.

\subsection{Wastewater}

8.11 Treatment Plant Influent

The effluent from the treatment plant shall be sampled and tested as follows :

Daily

Weekly

Monthly

Sem1Annually

Annua11y

5 Years
Flow

Specific Conductance

PH

5-Day Blochemical Oxygen Demand (B.O.D.)

Total Suspended Solids (T.S.S.)

Coliform Bacteria

Fecal Coliform Bacteria

Total Kjeldahl Nitrogen

Ammonia Nitrogen

Nitrate Nitrogen

Total Dissolved Solids

Sodium

011 and Grease

Volat1le Organic Compounds (USEPA Procedure 624 )

Arsenic

Barium

Cadmium

Chromium

Fluoride

Lead

Copper

Zinc

Mercury

Total Trihalomethanes

Selenium

Silver

Pesticides

Radioactivity 
All sampling and analyses, except for the daily and weekly frequency tests which will commence at time of plant startup, shail be performed initially at 60 days after plant startup and at the stated frequency thereaf ter.

8.20 Ground Water Monitor Wells

Monitor well testing in the upgradient and down gradient wells shall be performed semiannually in the months of April and September for all parameters designated above as semiannually or more often. Testing for other parameters shall be at the stated frequency, either annually or every 5 years during the month of April.

On an annual basis, the Board of Health, either on its own motion or upon written request from the permittee, may review the sampling frequency and the tested parameters and may modify either or both if it deems it necessary.

9.00 Operation

9.10 Operator

A Certified Waste Water Treatment Plant Operator having the Grade appropriate for the plant as determined by the regulations of the Board of Certification of Operators of Waste Water Treatment Facilities shall be retained by the permittee. Such operator shall spend a minimum of three (3) hours per day at the plant. When conditions warrant as may be determined by the Board of Health, additional hours shall be required. Such operator shall be designated by the Chief Operator and shall be responsible for the operation of the SWWTP.

\subsection{Back-up Operator}

A second Certified Waste Water Treatment Plant Operator, having the same grade as the Chief Operator shall be available in the absence of the Chief Operator.

\subsection{Operational Guarantee}

Prior to issuance of the Certificate of Compliance and Operations Permit, the permittee shall provide security in an amount specified by the Board of Health to guarantee the operation of the SWWTP for a period of at least one year. The security shall provide for salaries, operational costs, and cost for immediate replacement, if necessary, of a major unit operation of the plant, or in the event of plant failure to operate, an amount sufficient to cover the costs of hauling $100 \%$ of the waste water to another facility for disposal for a one year period.

\subsection{Severability}

If any part or portions of these regulations should be adjudicated as Invalid, the adjudication shall apply only to the material so adjudged, and the remaining Rules \& Regulations shall be deemed valid and of full force and effect. 